\title{
SPARTAN-A Simple Performance Assessment Code for the Nevada Nuclear Waste Storage Investigations Project
}

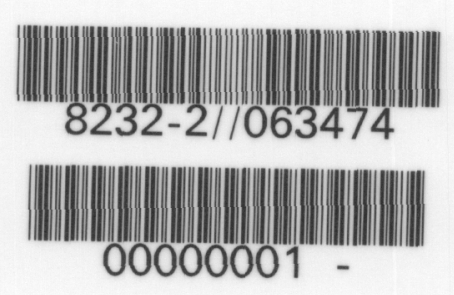

Y. T. Lin

\section{Prepared by}

Sandia National Laboratories

Albuquerque, New Mexico 87185 and Livermore, California 94550

for the United States Department of Energy

under Contract DE-AC04-76DP00789 
"Prepared by Nevada Nuclear Waste Storage Investigations (NNWSI) Project participants as part of the Civilian Radioactive Waste Management Program (CRWM). The NNWSI Project is managed by the Waste Management Project Office (WMPO) of the U. S. Department of Energy, Nevada Operations Office (DOE/NV). NNWSI Project work is sponsored by the Office of Geologic Repositories (OGR) of the DOE Office of Civilian Radioactive Waste Management (OCRWM)."

Issued by Sandia National Laboratories, operated for the United States Department of Energy by Sandia Corporation.

NOTICE: This report was prepared as an account of work sponsored by an agency of the United States Government. Neither the United States Government nor any agency thereof, nor any of their employees, nor any of their contractors, subcontractors, or their employees, makes any warranty, express or implied, or assumes any legal liability or responsibility for the accuracy, completeness, or usefulness of any information, apparatus, product, or process disclosed, or represents that its use would not infringe privately owned rights. Reference herein to any specific commercial product, privately owned rights. Reference herein to any specific commercial product,
process, or service by trade name, trademark, manufacturer, or otherwise, does not necessarily constitute or imply its endorsement, recommendation or favoring by the United States Government, any agency thereof or any of their contractors or subcontractors. The views and opinions expressed herein do not necessarily state or reflect those of the United States Government any agency thereof or any of their contractors or subcontractors.

Printed in the United States of America Available from

National Technical Information Service

U.S. Department of Commerce

5285 Port Royal Road

Springfield, VA 22161

NTIS price codes

Printed copy: A04

Microfiche copy: A01 
Distribution

Category UC-70

SAND85-0602

Unlimited Release

Printed December 1985

\author{
SPARTAN--A SIMPLE PERFORYANCE ASSESSMENT CODE \\ FOR THE NEVADA NUCLEAR WASTE STORAGE \\ INVESTIGATIONS PROJECT
}

\author{
by \\ Y. T. Lin \\ Geoscience Analysis Division \\ Sandia National Laboratories \\ Albuquerque, New Mexico $\mathbf{8 7 1 8 5}$
}

\begin{abstract}
SPARTAN is a simple computer model designed for the Nevada Nuclear Waste Storage Investigations Project to calculate radionuclide transport in geologic media. The physical processes considered are limited to Darcy's flow, radionuclide decay, and convective transport with constant retardation of radionuclides relative to water flow. Inputs for the model must be provided for the geometry, repository area, flow path, water $f l u x$, effective porosity, initial inventory, waste solubility, canister lifetime, and retardation factors. Results from the model consist of radionuclide release rates from the prospective Yucca Mountain repository for radioactive waste and cumulative curies released across the flow boundaries at the end of the flow path. The rates of release from the repository relative to NRC performance objectives and releases to the accessible environment relative to EPA requirements are also calculated. Two test problems compare the results of simulations from SPARTAN with analytical solutions. The comparisons show that the SPARTAN solution closely matches the analytical solutions across a range of conditions that approximate those that might occur at Yucca Mountain.
\end{abstract}




\section{ACKNOWLEDGMENTS}

The author would like to thank Professor T. H. Pigford and Dr. S. Kajiwara of Lawrence Berkeley Laboratory for providing the UCB NE-10 computer programs. Special thanks also given to Ms. Betsy Barnett for her numerous suggestions and helpful editorial improvements and to Ms. Mary Bachicha for many word processing and typing responsibilities involved in this report. 
1. INTRODUCTION . . . . . . . . . . . . . . . . . . . . . . 1

2. MATHEMATICAL BASIS OF THE SPARTAN MODEL . . . . . . . . . . . . . . 4

2.1 Water flow . . . . . . . . . . . . . . . . . . . . . . 4

2.2 Waste Dissolution... . . . . . . . . . . . . . . . . 7

2.3 Radionuclide Transport . . . . . . . . . . . . . . . . . 10

2.4 Release to the Accessible Environment... . . . . . . . . . 13

3. DESCRIPTION OF SAMPLE PROBLEMS . . . . . . . . . . . . . . . . . . . 17

3.1 General Assumptions . . . . . . . . . . . . . . . . . . . . . . 18

3.2 Problem 1 - Flux of $0.5 \mathrm{~mm} / \mathrm{yr}$. . . . . . . . . . . . . . . 18

3.2.1 SPARTAN Solution .. . . . . . . . . . . . . . . 20

3.2.2 Analytical Solution . . . . . . . . . . . . . . . 20

3.2.3 Comparison of the Results . . . . . . . . . . . . . 24

3.3 Problem 2 - Flux of $5 \mathrm{~mm} / \mathrm{yr}$. . . . . . . . . . . . . . . 25

3.3.1 SPARTAN Solution... . . . . . . . . . . . . . . 26

3.3.2 Analytical Solution . . . . . . . . . . . . . . . 26

3.3.3 Comparison of the Results . . . . . . . . . . . 30

4. CONCLUSIONS . . . . . . . . . . . . . . . . . . . . . . . 33

5. REFERENCES . . . . . . . . . . . . . . . . . . 34

6. APPENDIX A.......................... . . . . 37

7. APPENDIX B........................... . . . 41 
TABLES

1 Radionuclide Inventory of Spent Fuel and Allowable Release Limits of the NRC and EPA . . . . . . . . . . . . . . . . . . 11

2 Sorption Values and Retardation Factors . . . . . . . . . . . $\quad$. 19

3 Input Values of Parameters for Problem 1 . . . . . . . . . . . 20

4 Cumulative Curies Released to the Accessible Environment Through Path B for Problem 1. . . . . . . . . . . . . . . . 22

5 Input Values of Parameters for Problem 2 . . . . . . . . . . . 25

6 Cumulative Curies Released to the Accessible Environment Through Path A for Problem 2 . . . . . . . . . . . . . . . . 31

7 Cumulative Curies Released to the Accessible Environment Through Path B for Problem 2 . . . . . . . . . . . . . . . . 31

8 Cumulative Curies Released to the Accessible Environment Through Path C for Problem 2 . . . . . . . . . . . . . . . 


\section{FIGURES}

Eigure

1 Schematic Representation of Conceptual Geometric Model Used in Calculating Releases of Radionuclides from a Repository at

Yucca Mountain . . . . . . . . . . . . . . . . . . . .

2 Cumulative Curies of Individual Radionuclides Reaching the Accessible Environment Through Path B in Problem 1.... . .

Cumulative Curies of Individual Radionuclides Reaching the Accessible Environment Through Path A in Problem 2......

Cumulative Curies of Individual Radionuclides Reaching the Accessible Environment Through Path B in Problem 2..... .

Cumulative Curies of Individual Radionuclides Reaching the Accessible Environment Through Path $\mathrm{C}$ in Problem 2..... . 


\subsection{INTRODUCTION}

The Nevada Nuclear Waste Storage Investigations (NNWSI) Project is investigating the possibility of locating a repository for high-level radioactive waste at Yucca Mountain in southern Nevada. Yucca Mountain is located along the southwest corner of the Nevada Test site (NTS) and on adjacent federal property in southern Nevada. The conceptual design and assessment of performance for the repository are being performed by Sandia National Laboratories (SNL) under the direction of the Department of Energy's (DOE's) Nevada Operations office, which manages the NNWSI Project. SNL is conducting this effort in cooperation with Los Alamos National Laboratory (LANL), Lawrence Livermore National Laboratory (LLNL), and the U.S. Geological Survey (USGS).

One of the principal programmatic emphases of the NNWSI Project is assessment of repository performance, that is, the ability of the repository to isolate high-level radioactive wastes for tens to hundreds of thousands of years. One of the objectives of performance assessment is to predict as accurately as possible the rate at which radionuclides would be released to the accessible environment (in this report, the water table) in the event of a breach in waste containment. A computer model that provides simple performance Assessment of Radionuclide Transport at Nevada (SPARTAN) has been developed to make these predictions.

This report describes the SPARTAN model and its use in solving problems involving water flow through the waste disposal area and transport of soluble radionuclides to the water table. The SPARTAN model was developed to support the environmental assessment document for the potential Yucca Mountain repository (DOE, 1984). The SPARTAN model simulates one-dimensional, dispersionless transport of radionuclides in a multiple-flow-path, homogeneous, geologic medium with sorption in a constant-velocity field. It was initially designed for system studies and found to be an effective tool for simulation of the performance of the repository systems at Yucca Mountain (Sinnock et al., 1984). 
The physical processes considered in SPARTAN are limited to Darcy's flow, congruent leaching, radionuclide decay, and convective transport with retardation of radionuclides relative to water flow. This simple approach has been taken to estimate radionuclide migration in geologic media because many of the data and parameters needed to simulate a more detailed physical process are not available at this time. SPARTAN can be used to simulate the problems both in a porous matrix and in fractured media. Water flow, the rate of decay of each radionuclide, and radionuclide transport are simulated directly to calculate the number of curies released to the accessible environment over a time of interest, taking all three of these processes into account. The performance of the repository is measured by the rates of release from the repository relative to NRC performance objectives (NRC, 1983) and the cumulative curies released to the accessible environment relative to EPA standards (EPA, 1984).

It is not the intent of this report to establish the conceptual model of the Yucca Mountain repository site or to formally document and verify SPARTAN. Rather, this report provides some insight into the mathematical basis of SPARTAN and substantiates the accuracy of the code in a preliminary manner. Two problems are simulated to demonstrate SPARTAN's capabilities. The problems selected represent the range of groundwater recharge fluxes at Yucca Mountain. The first problem consists of a $0.5-\mathrm{mm} / \mathrm{yr}$ flux in the matrix of the unsaturated zone. This problem represents the flux expected at Yucca Mountain, given the existing climatic and subsurface conditions. In the second problem, a groundwater recharge flux of $5 \mathrm{~mm} / \mathrm{yr}$ involves flow in both matrix and fractures. This rate of recharge will probably not occur because the unsaturated zone would have to become sufficiently saturated to cause water to flow through the fractures, which is unlikely under the existing climatic and subsurface conditions at Yucca Mountain (Sinnock et al., 1984). Radionuclide transport to the water table is calculated for both circumstances. The accuracy of the results is examined by means of comparisons with analytical solutions. Details of test problems with relevant data and assumptions are taken directly from sinnock et al. (1984). 
Section 2 of this report contains a description of the SPARTAN model. Section 3 contains descriptions of the two scenarios, discusses SPARTAN's solutions and the analytical solutions, and compares the results of the SPARTAN and analytical solutions. Section 4 provides conclusions. Two appendices are provided: Appendix A contains a computer listing for SPARTAN, and Appendix B contains the computer program and input data used to calculate the analytical solution. 


\subsection{MATHEMATICAL BASIS OF THE SPARTAN MODEL}

The following mathematical principles and assumptions served as the basis for formulation of the series of computer algorithms that make up the SPARTAN model. The computer program used to calculate the test problems in section 3 is provided in Appendix $A$.

A repository, as depicted in Figure 1 , is assumed to contain $M(t)$ metric tons of heavy metal radioactive waste in a planar horizon distributed over an area expressed in square meters. The repository is assumed to be at a height, $\mathrm{H}$, in meters above the water table. The volume of groundwater that flows vertically downward through the unsaturated zone from a unit area at the disposal horizon per unit of time is called the flux and is assumed to be a parameter, F, given in $\mathrm{m}^{3} / \mathrm{m}^{2} / \mathrm{yr}$. Flow in the unsaturated zone is assumed to obey Darcy's law. The boundary of the accessible environment is assumed to occur in the saturated zone a distance 2 to $10 \mathrm{~km}$ downgradient of the repository. Though not considered in the test problems presented later, water flow time through the saturated zone is treated in SPARTAN as a constant parameter, $\mathbf{T}$.

\subsection{Water Flow}

The subscript, $j$, identifies the two components of the medium (porous matrix and fractures); $j=1$ denotes the matrix and $j=2$ denotes the fractures. Darcy's law for the steady state of flow in both the matrix and fractures is expressed by

$$
F_{j}=-K_{j} \frac{d h_{j}}{d 1} \quad\left(m^{3} / m^{2} / y r\right)
$$

\footnotetext{
where $h_{j}$ is hydraulic head, $\frac{d h_{j}}{d 1}$ is the hydraulic gradient, $k_{j}$ is the hydraulic conductivity, and $F_{j}$ is called "Darcy velocity" or "Darcy flux." For water percolating vertically downward through a uniform profile to a
} 


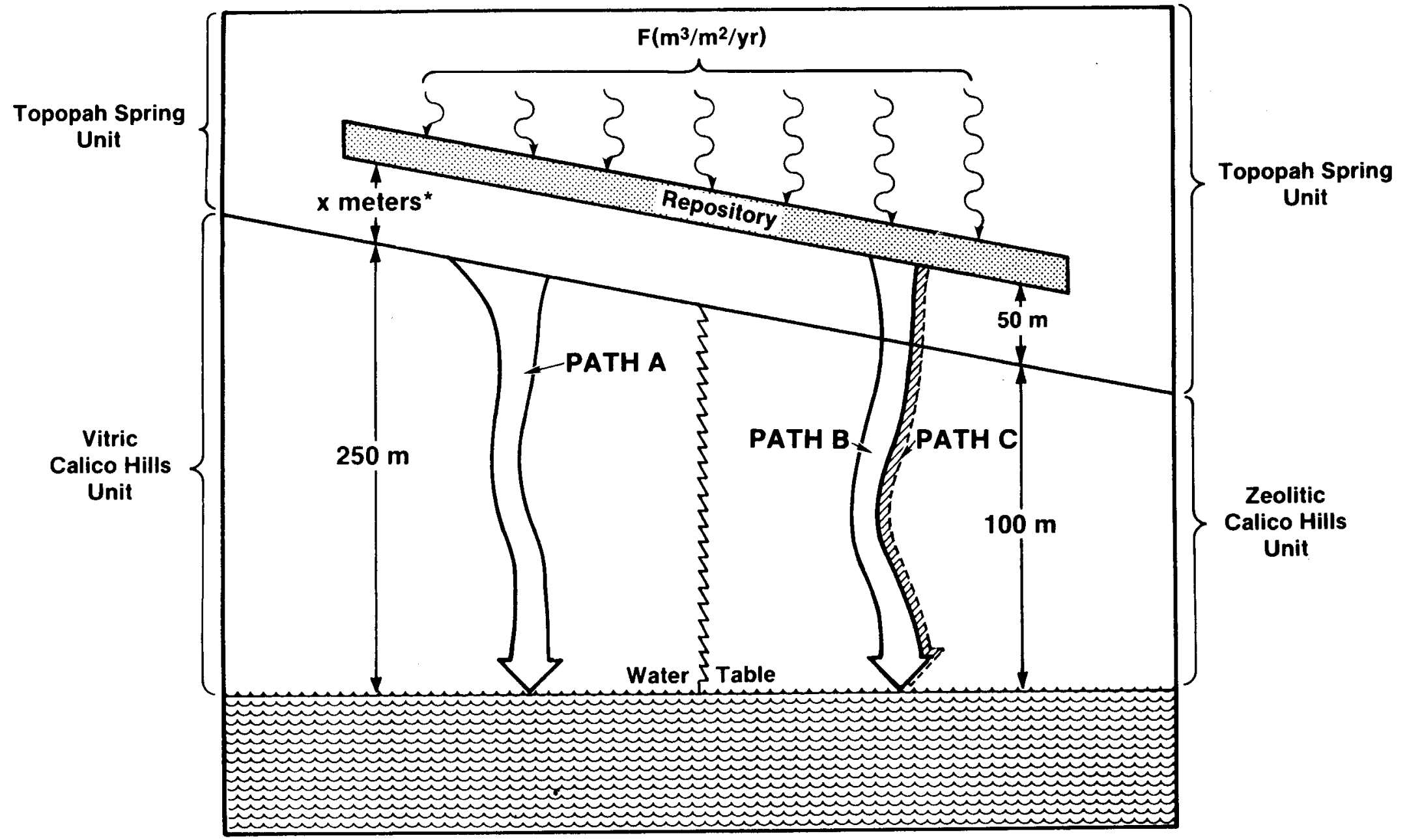

PATH A: Matrix flow for all values of flux.

PATH B: Matrix flow for flux up to $1 \mathrm{~mm} / \mathrm{yr}$.

PATH C: Fracture flow for flux in excess of $1 \mathrm{~mm} / \mathrm{yr}$; identical properties assumed for Topopah Spring and Calico Hills units.

\section{*Undefined thickness of Topopah Spring unit ignored in calculations}

Figure 1. Schematic Representation of Conceptual Geometric Model Used in Calculating Releases of Radionuclides from a Repository at Yucca Mountain 
stationary water table, $\frac{d h}{d l}$ is assumed to be -1 . The flux through the $j^{\text {th }}$ medium cannot exceed the maximum hydraulic conductivity of the $j^{\text {th }}$ medium. Thus, if the flux is less than the saturated conductivity of the matrix, $\mathrm{K}_{j=1}^{s}$, it is assumed that the flux flows through the porous matrix, and the effective hydraulic conductivity and the gradient will adjust to satisfy Equation 1. If the flux is greater than $k_{j=1}^{s}$, the excess flux, $F_{j=2}$, will flow through fractures of sufficient conductivity to satisfy Equation 1 .

The average particle velocity of water, $v_{j}$, is

$$
v_{j}=\frac{F_{j}}{n_{j}} \quad(m / y r)
$$

where $n_{j}$ is the effective porosity of the $j^{\text {th }}$ medium. The water travel time, $T_{j}^{u}$, through $H_{j}$ thickness of the unsaturated zone in meters is

$$
T_{j}^{u}=\frac{H_{j} n_{j}}{F_{j}} \quad(y r)
$$

Saturated flow time is treated as a parameter, $T^{\mathbf{S}}$. The total water travel time, $T_{j}^{w}$, from the repository to the accessible environment is the sum of travel time in the saturated zone, $T^{\mathbf{s}}$, and the travel time in the unsaturated zone and is

$$
T_{j}^{w}=T_{j}^{u}+T^{s} \quad(y r)
$$

Assigning a value of zero to $T^{\mathbf{s}}$, as done for this report, allows a consideration of flow only to the water table. 


\subsection{Waste Dissolution}

The flux that passes through the repository level may intercept the radioactive waste. The maximum volume of water that could interact annually with the waste, for either matrix or fracture flow, is the total flow through the repository area and is given by

$$
Q_{j}=F_{j} \cdot A \quad\left(m^{3} / y r\right)
$$

where $Q_{j}$ is the annual flow rate through $j^{\text {th }}$ medium, $F_{j}$ is the annual flux through $j^{\text {th }}$ medium, and $A$ is the total area of the repository. Assuming only one-dimensional vertical flow, the annual amount of water in cubic meters actually intercepting the waste emplacement area, $q_{j}$, is less than $Q_{j}$ and is given by

$$
q_{j}=F_{j} \cdot A \cdot \alpha_{j} \quad\left(m^{3} / y r\right)
$$

where $\alpha_{j}$ is the ratio of the area occupied by the waste (i.e., the effective cross-sectional area for water flow intercepted by emplaced waste canisters or their emplacement holes) to the total repository area.

The water intercepting the actual waste emplacement area will not contact radioactive waste unless a canister fails. Canister failure is treated in two simple ways: (1) a constant lifetime of either 300 or $1,000 \mathrm{yr}$ represents the time of immediate and simultaneous failure of all canisters, i.e., having a step function at the constant lifetime, $T_{f}$

$$
G(t)=U\left(t-T_{f}\right)
$$

where

$$
\begin{aligned}
& U\left(t-T_{f}\right)=0 \text { if } t \leq T_{f} \\
& U\left(t-T_{f}\right)=1 \text { if } t>T_{f}
\end{aligned}
$$


and (2) a variable lifetime represents the exponential lifetime distribution of the canister failure, i.e., having a probability density function of

$$
g(t)=\left\{\begin{array}{lll}
\frac{1}{\mu} & \exp (-t / \mu) & t \geq 0 \\
0 & & t<0
\end{array}\right.
$$

for which the cumulative distribution is

$$
G(t)=\int_{-\infty}^{t} g(y) d y=\left\{\begin{array}{ll}
1-\exp (-t / \mu) & t \geq 0 \\
0 & t<0
\end{array} .\right.
$$

The parameter $\mu$ is the mean time-to-failure of the waste canisters. Though SPARTAN has the capability to use variable lifetimes, only a constant lifetime of $300 \mathrm{yr}$ is used in the sample problems.

It is assumed that wastes contacted by water dissolve congruently with uranium on a mass basis. Thus, given a solubility limit of uranium, $s_{i=u}\left(\mathrm{~kg} / \mathrm{m}^{3}\right)$, the expected annual dissolution rate for uranium is given by

$$
D_{i=u, j}(t)=q_{j} \cdot s_{i=u} \cdot G(t) \quad(k g / y r) .
$$

For the $i^{\text {th }}$ radionuclide, the annual dissolution rate is given by

$$
D_{i, j}(t)=D_{i=u, j}(t) \cdot \frac{m_{i}(t)}{m_{i=u}(t)} \quad(k g / y r)
$$

where $m_{i}(t)$ is the inventory of $i^{\text {th }}$ radionuclide in kilograms at time, $t$, and $i=u$ represents uranium. Because it is assumed that radionuclides dissolve instantaneously when they come in contact with water, the mass release rate to water is the same as the dissolution rate. The total 
amount of waste released, $\sum_{i=1}^{N} \Delta m_{i}(t)$, is simply the sum of dissolved amounts for all radionuclides.

$$
\sum_{i=1}^{N} \Delta m_{i}(t)=\sum_{i=1}^{N} \sum_{j=1}^{M} D_{i, j}(t) \quad(k g / y r)
$$

where $N$ is the number of radionuclide species, and $M$ is the number of pathway types.

The annual fractional release rate is defined as

$$
R=\frac{\sum_{i=1}^{N} \Delta m_{i}(t)}{\sum_{i=1}^{N} m_{i}(t)} \quad\left(y^{-1}\right)
$$

Allowing water to dissolve the wastes and assuming releases based on a high solubility for uranium results in an overestimation of waste dissolution in the repository. A more realistic approach is to use masstransfer theories to estimate the time-dependent dissolution rate of waste material in a geological repository (Chambré et al., 1982). However, the first approach, which is used in SPARTAN, can reveal the unique natural qualities of the site, which will contribute to waste containment independently of engineered features.

Given an initial inventory of radionuclides, the mass of any radionuclide $m_{i}(t)$, and $\Delta m_{i}(t)$ that is present at some time $(t)$ after the initial time, $t_{0}$, can be computed analytically by solving a system of ordinary differential equations that describe radiocative decay (Bateman, 1910). 
The rate of curies released annually for the $i^{\text {th }}$ species to the water flowing through the $j^{\text {th }}$ medium, $c_{i, j}$, is the product of specific activity, $a_{i}$, and annual dissolution rate, $D_{i, j}$

$$
C_{i, j}(t)=a_{i} D_{i, j}(t) \quad(C i / y r)
$$

Though not used in the test problems presented later, SPARTAN has the capability to assess the annual release rate for each radionuclide in terms of the NRC performance objectives (NRC, 1983). An "NRC Ratio," $\mathrm{NR}_{i}$, can be calculated from

$$
N R_{i}=\frac{\sum_{j=1}^{2} c_{i, j}(t)}{N L_{i}}
$$

where $\mathrm{NL}_{i}$ is the $\mathrm{NRC}$ release limit for the $i^{\text {th }}$ radionuclide defined in Table 1. Similarly, a total NRC ratio for all radionuclides can be computed with

$$
\mathrm{NR}=\sum_{i=1}^{N} \mathrm{NR}_{\mathbf{i}}
$$

\subsection{Radionuclide Transport}

The transport time for the $i^{\text {th }}$ radionuclide, $T_{i, j}^{r}$, is related to the water travel time by

$$
T_{i, j}^{r}=R_{i, j} T_{j}^{W} \quad(y r)
$$


TABLE 1

RADIONUCLIDE IUVERTORY OF SPEMT FUEL AMD ALLOWABLE RELEASB LIMITS OF THB WRC AND BPA

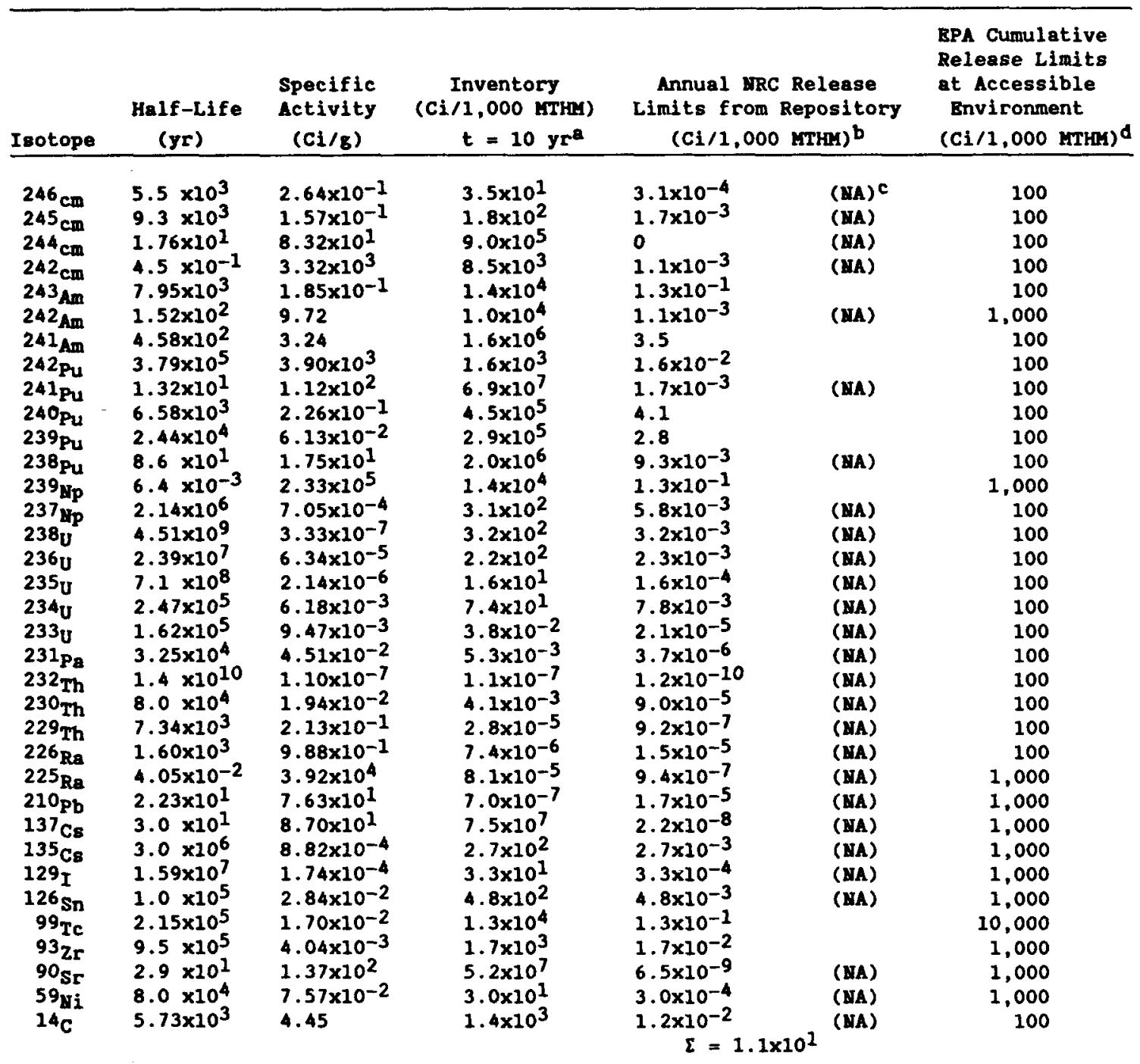

a. $10 \mathrm{yr}$ out of the reactor, i.e., the assumed time of emplacement (DOR, 1979).

b. $1 \times 10^{-5}$ times inventory at 1,060 yr (RRC, 1983).

c. Mn means not applicable; curies remaining at 1,060 yr are less than about $1.1 \times 10^{-2} \mathrm{Ci}_{\text {, }}$ i.e. less than 0.17 of the total release rate 1 imit of about $11 \mathrm{ci} / \mathrm{yr}$; each of these nuclides thus has a release rate 1 imit of $1.1 \times 10^{-2} \mathrm{ci} / \mathrm{yr}$.

d. Applied 10,000 yr after repository closure (BPA, 1984). 
where $R d_{i, j}$ is a dimensionless retardation factor for the $i^{\text {th }}$ radionuclide through the $j^{\text {th }}$ medium. For porous flow, $i . e, j=1$, the retardation factor is defined as

$$
\mathrm{Rd}_{i, 1}=1+\frac{\gamma \mathrm{Kd}_{i}}{\mathrm{n}_{1}}
$$

where the $Y$ is the bulk rock density $\left(\mathrm{kg} / \mathrm{m}^{3}\right), \mathrm{Kd}_{i}$ is the distribution coefficient $\left(\mathrm{m}^{3} / \mathrm{kg}\right)$ or sorption ratio for the $i^{\text {th }}{ }_{\text {radionuclide in porous }}$ matrix blocks, and $n_{1}$ is the effective porosity of the blocks.

In the case of water flow through fractures, i.e., $j=2$, it is more appropriate, as suggested by Burkholder (1976), to relate the retardation factor to a distribution coefficient, $\mathrm{Ka}_{i}$, by the equation

$$
\operatorname{Rd}_{i, 2}=1+\operatorname{Rf} \mathrm{Ka}_{\mathbf{i}}
$$

where Rf is the ratio of surface area to void space (volume) for the fracture opening through which the radionuclide is being transported. $\mathrm{Ka}_{i}$ is a measure of moles of the $i^{\text {th }}$ radionuclide in the sorbed state per unit of surface area divided by the moles of the $i^{\text {th }}$ nuclide in the dissolved state per unit volume of groundwater when the groundwater and sorbing medium are in equilibrium. Because the fracture surfaces are generally irregular, the actual surface area with which the radionuclide reacts is unknown. A simple approach is to express $\mathrm{Ka}_{i}$ in terms of the area of an assumed planar fracture surface (Freeze and Cherry, 1979; p. 410). In this case, retardation factors for fracture flow may be computed as

$$
\mathrm{Rd}_{i, 2}=1+\frac{2 \mathrm{Ka}}{\mathrm{b}}
$$

where $b$ is the width of the fracture aperture. 
The differential equation describing the one-dimensional transport of radionuclides and their decay products through geologic media with sorption is listed below.

$$
R_{\ell, j} \frac{\partial N_{\ell, j}}{\partial t}+v_{j} \frac{\partial N_{\ell, j}}{\partial z}+R d_{\ell, j} \lambda_{\ell} N_{\ell, j}=R d_{\ell-1, j} \lambda_{\ell-1} N_{\ell-1, j}
$$

where

$$
\begin{aligned}
\mathbf{N}_{\ell, j}= & \text { radionuclide concentration for the } \ell^{\text {th }} \text { member of the } \\
& \text { decay chain through the } j^{\text {th }} \text { medium, } \\
\mathrm{Rd}_{\ell, j}= & \text { retardation factor for the } \ell^{\text {th }} \text { member of the decay chain } \\
& \text { through the } j^{\text {th }} \text { medium, } \\
\lambda_{\ell}= & \text { decay constant for the } \ell^{\text {th }} \text { member of the decay chain } \\
\mathbf{v}_{j}= & \text { where } \lambda_{0}=0 \text {, and groundwater velocity through the } j \\
& \text { medium. }
\end{aligned}
$$

Hydrodynamic dispersion and diffusion are not considered in these equations.

\subsection{Release to the Accessible Environment}

The amount of curies released to the accessible environment may be expressed in curies as $c_{i, j}^{a}$. This quantity is obtained by decaying the curies of each radionuclide dissolved (Equation 11) for the time period represented by the retarded radionuclide transport time (Equation 17) from the repository to the accessible environment.

$c_{i, j}^{a}$ is computed by a direct-simulation approach that defines numerical matrices that represent the material balances of the $\ell^{\text {th }}$ members of decay chains and all preceding chain members (Equation 21) over a differential length of flow path and a differential time. The annual amount of curies at any time after dissolution from the repository, $c_{i, j}(t)$, is modeled during transport as a set of discrete lumped slugs. Each slug, by definition, consists of a discrete quantity of curies, $\left(C_{p}\right)_{i, j}$, approximated by 


$$
\left(c_{p}\right)_{i, j}=\left(c_{i, j}^{k}+c_{i, j}^{k+1}\right) \frac{\Delta t_{k}}{2}
$$

where

$$
\begin{aligned}
& \Delta t_{k}=\text { the time increment for the } k^{t h} \text { time step } \\
& C^{k}{ }_{i, j}=\text { the curie release rate of the } k^{\text {th }} \text { time step } \\
& C_{i, j}^{k+1}=\text { the curie release rate at the }(k+1)^{t h} \text { time step } \\
& \mathrm{p} \quad=\text { the slug index, } p=1,2,3, \ldots \mathrm{NP} \text {, and } \mathrm{NP} \text { is the number } \\
& \text { of slugs. }
\end{aligned}
$$

In addition, each $\left(C_{p}\right)_{i, j}$ is associated with a discrete spatial coordinate $\left(z_{p}\right)_{i, j}$. Therefore, at any location, $\left(z_{p}\right)_{i, j}$, and at any time, $t$, there is an associated discrete curie content, $\left(c_{p}\right)_{i, j}(t)$.

During a given time step, the velocity of the $i^{\text {th }}$ radionuclide in the $j^{\text {th }}$ medium of each slug is computed from the characteristics of convective mechanisms

$$
\frac{d\left(z_{p}\right)_{i, j}}{d t}=\frac{v_{j}}{R d_{i, j}}
$$

where

$v_{j}=$ water velocity along the $j^{\text {th }}$ flow path in the $z$ direction. The new location of the slug at the $(k+1)^{\text {th }}$ time step is calculated by

$$
\left(z_{p}^{k+1}\right)_{i, j}=\left(z_{p}^{k}\right)_{i, j}+\Delta t_{k} \frac{v_{j}}{R d_{i, j}}
$$


where

$$
\begin{aligned}
& \Delta t_{k}=\text { the time increment for the } k^{\text {th }} \text { time step } \\
& \left(z_{p}^{k}\right)_{i, j}=\text { the } z \text { location of the slug } p \text { at the } k^{\text {th }} \text { time step } \\
& \left(z_{p}^{k+1}\right)_{i, j}=\text { the } z \text { location of the slug } p \text { at the }(k+1)^{\text {th }} \text { time step. }
\end{aligned}
$$

The slugs in the flow path and the source term at the repository are adjusted for radioactive decay in each time step by solving the Bateman equations. A five-member chain of equations is used in computation of radionuclide quantities as a function of time. For the decay chains with very rapidly decaying nuclides, each of the short-lived radionuclides, i.e., $\mathrm{Pu}-241, \mathrm{Ra}-225, \mathrm{Cm}-242, \mathrm{~Pb}-210$, and $\mathrm{Np}-239$, is assumed to remain in secular equilibrium with its immediate precursor. No branching ratios are considered in the decay chains.

The curies released to the accessible environment at $z^{a} \mathrm{~m}$ from the repository, $c_{i, j}^{a}$, is the sum of slugs transported to the spatial coordinates corresponding to the boundary of the accessible environment, i.e., $\left(z_{p}\right)_{i, j} \geq z^{a}$. Cumulative curies released to the accessable environment for the $i^{\text {th }}$ radionuclide along the $j^{\text {th }}$ path, $\bar{c}_{i, j}^{a}$, are the curies in all slugs reaching the boundary integrated from time 0 to $t$.

$$
\bar{c}_{i, j}^{a}(t)=\sum_{k=1}^{k} \sum_{p=1}^{N}\left(c_{p}\right)_{i, j}(t)
$$

for $\left(z_{p}\right)_{i, j} \geq z^{a}$ where $k$ is the index for time steps, and $k$ is the number of time steps.

Though the capability is not illustrated in the test problems, SPARTAN can compare the performance of a site, i.e., the cumulative curies released to the accessible environment, with the EPA release requirements (EPA, 1984). The measure of performance is simply the "EPA release ratio" (ER), 


$$
E R=\sum_{i=1}^{N} \frac{\sum_{j=1}^{M} \bar{c}_{i, j}^{a}(t)}{E L_{i}}
$$

where $\mathrm{EL}_{i}$ is the EPA requirement for the $i^{\text {th }}$ radionuclide defined in Table 1. Both the "NRC Ratio" and "EPA Release Ratio" are implemented in SPARTAN. However, neither is presented in the sample problems discussed in the following section because the sample problems are intended to assess the accuracy of SPARTAN in terms of analytical solutions. The cumulative curies released, calculated by SPARTAN, are sufficient to provide the necessary comparisons. 


\subsection{DESCRIPTION OF SAMPLE PROBLEMS}

\subsection{General Assumptions}

This section describes the test problems used for calculation of cumulative releases of radionuclides to the accessible environment under an assumed conceptual repository model and site conditions at Yucca Mountain. The assumptions underlying the models and conditions used for this report are discussed in detail by sinnock et al. (1984) and are not elaborated in this report. However, it is necessary to itemize the relevant assumptions here to provide a basis for comparing radionuclide releases computed by SPARTAN and those computed by analytical solutions. The relevant assumptions are presented in the following paragraphs.

The stratum assessed for the prospective repository is located in the lower part of the Topopah Spring Member of the Paintbrush Tuff at Yucca Mountain. The total repository area is $6.07 \times 10^{6} \mathrm{~m}^{2}$. The repository will contain 70,000 metric tons of heavy metal (MTHM) in the form of canisters of spent fuel. At the time of emplacement, the spent fuel has been out of reactors for $10 \mathrm{yr}$, when it is all simultaneously emplaced in the repository. The inventory of waste assumed to be present at the time of emplacement is shown in Table 1. No waste will dissolve or leach from the emplacement location until the spent fuel is $360 \mathrm{yr}$ old ( $300 \mathrm{yr}$ after closure of the repository). No thermal effects are considered.

All releases of waste from the repository are caused by groundwater that flows through the repository. The amount of water flowing vertically to an area defined by the cross-sectional area of emplacement holes, $2.5 \%$ of the flow rate $\left(q_{j}\right)$, will interact with the waste. Two sample problems are presented here to demonstrate the results of the SPARTAN simulations and to compare those results with analytical solutions. Problem 1 uses a flux of $0.5 \mathrm{~mm} / \mathrm{yr}$; Problem 2 uses a flux of $5 \mathrm{~mm} / \mathrm{yr}$, which represents a situation involving fracture flow (Sinnock et al., 1984). The spent fuel dissolves at a rate that allows the interacting water to become saturated with uranium. The uranium solubility used is $4 \times 10^{-4} \mathrm{~kg} / \mathrm{m}^{3}$. Other radionuclides dissolve congruently with uranium on a mass basis. 
The flow path from the repository to the accessible environment is vertically downward through the unsaturated zone to the water table, which is taken to be the accessible environment. A schematic representation of the three pathway types considered is depicted in Figure 1. The first matrix-flow pathway (Path A) transmits all the flux for both problems $(0.5$ and $5.0 \mathrm{~mm} / \mathrm{yr}$ ) through the portion of the repository underlain by the vitric Calico Hills unit, which comprises $40 \%$ of the total repository area. The vitric Calico Hills unit is able to transmit all flux through the pores in the rock matrix. Path $A$ is $250 \mathrm{~m}$ long. The second matrix pathway (Path B) transmits all flux for the $0.5-\mathrm{mm} / \mathrm{yr}$ case and $1 \mathrm{~mm} / \mathrm{yr}$ for the $5-\mathrm{mm} / \mathrm{yr}$ case through the porous matrix of the Topopah Spring Member and zeolitic Calico Hills unit that under1ie $60 \%$ of the total repository area. The flow distance along Path $B$ to the water table is $150 \mathrm{~m}$. The third flow pathway (Path C) transmits the 4-mm/yr flux through fractures in the Topopah spring and zeolitic Calico Hills units for the $5-\mathrm{mm} / \mathrm{yr}$ case. The fracture flow pathway is geometrically coincident with Path B.

The values of retardation factors used for individual radionuclides are shown in Table 2. Matrix retardation values are used for flow Paths $A$ and $B$. For a flux of $4 \mathrm{~mm} / \mathrm{yr}$ in Problem 2, saturated-fracture-retardation values (Table 2) are used for Path $C$.

\subsection{Problem 1 - Flux of $0.5 \mathrm{~mm} / \mathrm{yr}$}

The input values of variables needed to calculate a solution to Problem 1 by both SPARTAN and the analytical solution are given in Table 3 . Output for this problem consists of the time-dependent cumulative curies for radionuclides that reach the accessible environment (in this case, assumed to be the water table) in $100,000 \mathrm{yr}$. For the $0.5-\mathrm{mm} / \mathrm{yr}$ flux, groundwater travel time from the repository to the water table is $100,000 \mathrm{yr}$ through Path A, 30,000 yr through Path $B$, and not applicable to Path $C$ because no fracture flow is computed for this flux. Therefore, the only two radionuclides, $\mathrm{C}-14$ and $\mathrm{I}-129$, that reach the water table in the first 100,000 yr travel along Path $B$ and initially arrive $30,000 \mathrm{yr}$ after closure of the repository. 
TABLE 2

SORPTION VALUES AND RETARDATION FACTORS

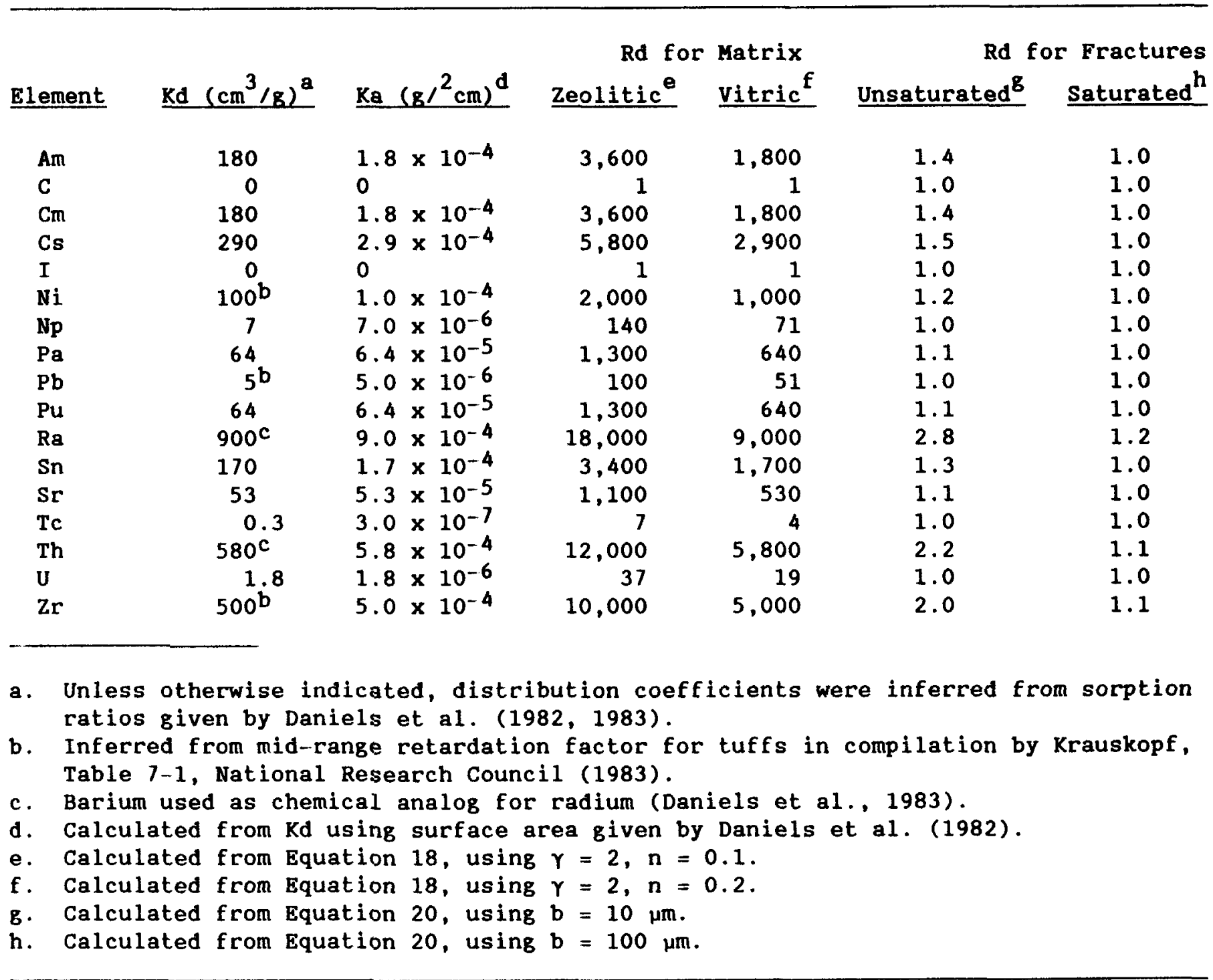




\section{TABLE 3}

INPUT VALUES OF PARAMETERS FOR PROBLEM 1

$\begin{array}{ll}\text { Flux through the unsaturated zone } & =0.5 \mathrm{~mm} / \mathrm{yr} \\ \text { Total repository area } & =6.07 \times 10^{6} \mathrm{~m}^{2} \\ \text { Portion of flux interacting with waste } & =2.5 \% \\ \text { Solubility of U } & =4 \times 10^{-4} \mathrm{~kg} / \mathrm{m}^{3} \\ \text { Waste package lifetime } & =300 \mathrm{yr} \text { after closure } \\ \text { Initial inventories } & =\text { those specified in Table } 1 \\ \text { Retardation factors } & =\text { those specified in Table } 2\end{array}$

\begin{tabular}{llllc} 
& \multicolumn{1}{c}{ Path A } & & \multicolumn{1}{c}{ Path B } & Path C \\
\cline { 2 - 2 } Distance to water table (m) & 250 & & \\
Effective porosity & 0.2 & & 150 & 150 \\
Water velocity $(\mathrm{m} / \mathrm{yr})$ & $2.5 \times 10^{-3}$ & & $5 \times 10^{-3}$ & 0.001 \\
Flow rate $\left(\mathrm{m}^{3} / \mathrm{yr}\right)$ & $3.04 \times 10^{1}$ & & $4.55 \times 10^{1}$ & 0 \\
Release rate $(1 / \mathrm{yr})$ & $1.79 \times 10^{-10}$ & & $2.68 \times 10^{-10}$ & 0 \\
& & &
\end{tabular}

\subsubsection{SPARTAN Solution}

Figure 2 and Table 4 show the cumulative curies released to the water table through Path B. Only two radionuclides, C-14 and I-129, reach the water table through Path $B$ in the first $100,000 \mathrm{yr}$ after repository closure because they are the only nonretarded radionuclides to migrate at the same rate as the flowing water. No other radionuclides reach the water table along Path B within the first 100,000 yr after repository closure.

\subsubsection{Analytical Solution}

The rate of change of the radionuclide inventory, $m_{i}(t)$, over time that results from a constant release rate from the repository, $r_{i}(t)$, and decay constant, $\lambda_{i}$, can be expressed by the following equation:

$$
\frac{d}{d t} m_{i}(t)=-\left[\lambda_{i}+r_{i}(t)\right] m_{i}(t)
$$




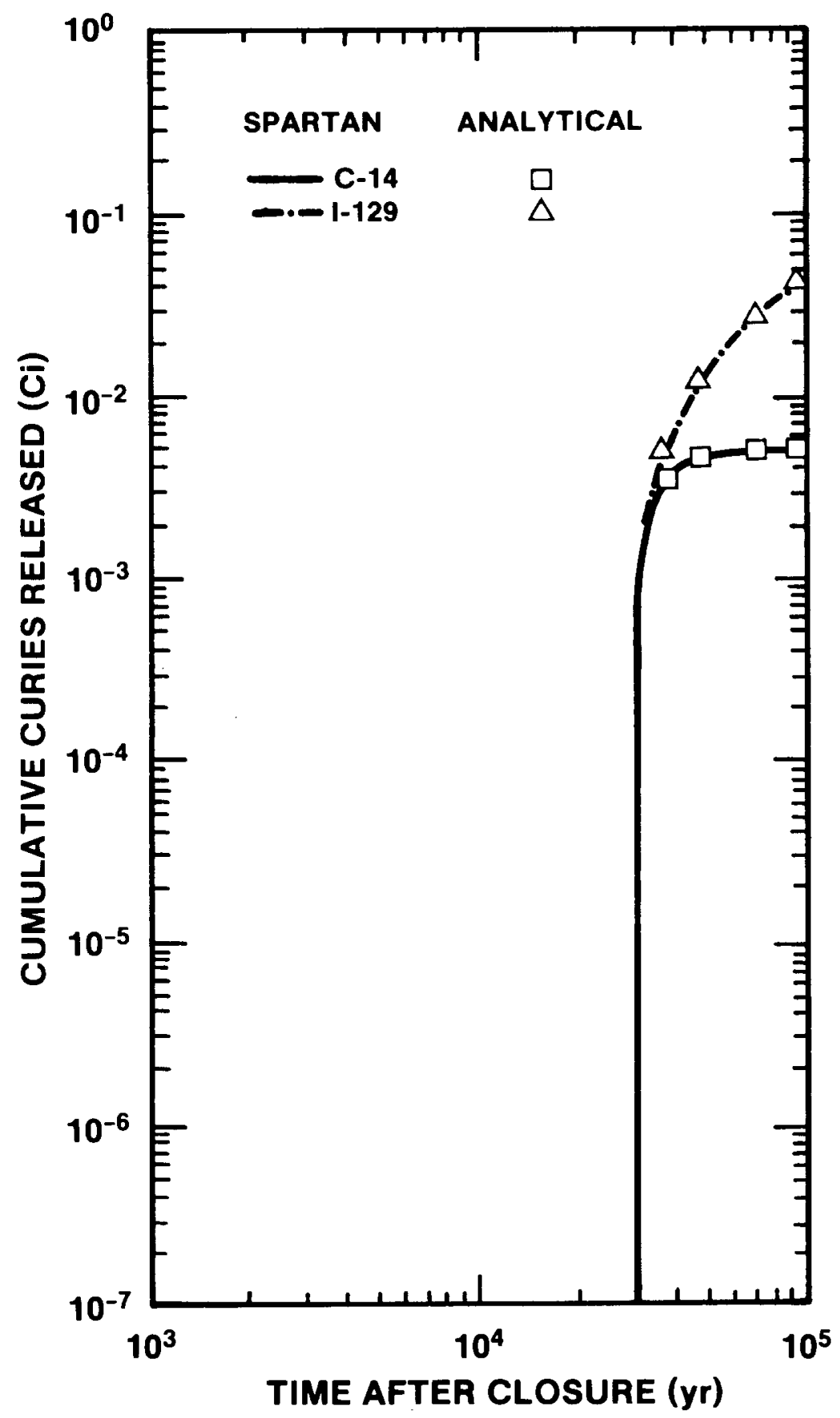

Figure 2. Cumulative Curies of Individual Radionuclides Reaching the Accessible Environment Through Path B in Problem 1. 
TABLE 4

CURULATIVE CURIES RELEASED TO THE ACCBSSIBLE EHVIROMMENT THROUGH PATH B FOR PROBLEG 1

Time After Closure (yr)

\begin{tabular}{|c|c|c|c|c|c|c|c|c|c|c|}
\hline \multirow{2}{*}{$\begin{array}{l}\text { Cumblative Curies } \\
\text { Released (Ci) }\end{array}$} & \multicolumn{2}{|c|}{$1 \times 10^{4}$} & \multicolumn{2}{|c|}{$4 \times 10^{4}$} & \multicolumn{2}{|c|}{$5 \times 10^{4}$} & \multicolumn{2}{|c|}{$7 \times 10^{4}$} & \multicolumn{2}{|c|}{$1 \times 10^{5}$} \\
\hline & SPARTAI & $\overline{\text { Analytical }}$ & SPARTA\& & Analytical & SPARTAN & Analytical & SPARTAN & $\overline{\text { Analytical }}$ & SPARTAN & Analytical \\
\hline$c-14$ & 0 & 0 & $3.44 \times 10^{-3}$ & $3.80 \times 10^{-3}$ & $4.47 \times 10^{-3}$ & $5.0 \times 10^{-3}$ & $4.87 \times 10^{-3}$ & $5.46 \times 10^{-3}$ & $4.91 \times 10^{-3}$ & $5.51 \times 10^{-3}$ \\
\hline$I-129$ & 0 & 0 & $6.21 \times 10^{-3}$ & $5.84 \times 10^{-3}$ & $1.24 \times 10^{-2}$ & $1.19 \times 10^{-2}$ & $2.48 \times 10^{-2}$ & $2.40 \times 10^{-2}$ & $4.34 \times 10^{-2}$ & $4.21 \times 10^{-2}$ \\
\hline
\end{tabular}


where

$$
\begin{aligned}
r_{i}(t)= & R U\left(t-T_{f}\right) \\
U\left(t-T_{f}\right)= & \text { the unit step function, defined in } \\
& \text { Equation } 7, \\
T_{f}= & \text { a constant canister lifetime of } 300 \mathrm{yr}, \\
R= & \text { a constant release rate defined in } \\
& \text { Equation } 13 .
\end{aligned}
$$

For a single-member chain or for the first member in a decay chain, the solution of the equation is

$$
m_{i}(t)=m_{i}(0) e^{-\lambda_{i} t} \quad 0 \leq t \leq T_{f}
$$

and

$$
m_{i}(t)=m_{i}(0) e^{-\lambda_{i} T_{f}} e^{-\left(\lambda_{i}+R\right)\left(t-T_{f}\right)} \quad t>T_{f} .
$$

The curie release rate for the $i^{\text {th }}$ radionuclide through the $j^{\text {th }}$ path, $c_{i, j}(t)$, at the repository is

$$
C_{i, j}(t)=a_{i} R m_{i}(0) e^{-\lambda_{i} T_{f}} e^{-\left(\lambda_{i}+R\right)\left(t-T_{f}\right)} \quad t>T_{f}
$$

The curie release rate to the accessible environment, $c_{i, j}(t)$, is the curie release rate at the repository retarded in time by the transport time and reduced by the radioactive decay for a time corresponding to the transport time from the repository to the accessible environment.

$$
c_{i, j}^{a}(t)=U\left(t-T_{i, j}^{r}\right) c_{i, j}\left(t-T_{i, j}^{r}\right) e^{-\lambda_{i} T_{i, j}^{r}}
$$


where

$$
\begin{aligned}
U\left(t-T_{i, j}^{r}\right)= & \text { the unit step function, } \\
T_{i, j}^{r}= & \text { the transport time of the } i^{\text {th }} \text { radionuclide to the } \\
& \text { accessible environment defined in Equation } 17 .
\end{aligned}
$$

Integrating $c_{i, j}^{a},(t)$ from 0 to $t$ yields the cumulative curies released to the accessible environment by time, $t$ :

$$
\bar{c}_{i, j}^{a}(t)=\frac{a_{i} R m_{i}(0)}{\left(\lambda_{i}+R\right)} e^{-\lambda_{i}\left(T_{f}+T_{i, j}^{r}\right)}\left[e^{-\left(\lambda_{i}+R\right)\left(t-T_{f}-T_{i, j}^{r}\right)}\right] .
$$

This analytical solution can be used to calculate the cumulative release of curies to the accessible environment for the single-member chains of $\mathrm{C}-14$ and I-129. The results of the analytical solution of Problem 1 are shown in Table 4.

\subsubsection{Comparison of the Results}

A comparison of the numerical results from the SPARTAN simulations and from the analytical numerical solutions in Table 4 indicates very close agreement between the numerical and analytical solutions. The results were plotted in Figure 2 , but a graphic presentation does not allow much discrimination between two solutions on a reasonable scale. The discrepancies are caused by approximations made in representing the curie releases and by the averaging process of the time-step integration method used to calculate the cumulative curies released. For each $k^{\text {th }}$ time step, the curie releases are approximated by an average curie release rate at the $k^{\text {th }}$ and $k+1^{\text {th }}$ time step multiplied by the timestep size. The cumulative releases are integrated only approximately 
by this procedure. The error from these approximations could be reduced by using a time step that is relatively small compared to the half-life of a radionuclide. However, the cost for computing time would increase when computing the 100,000-yr effects using smaller time steps. The results presented in Table 4 are based on a 1,000-yr time step; thus, the discrepancy for $\mathrm{C}-14$, which has a half-life of $5.73 \times 10^{3} \mathrm{yr}$, is greater than that for I-129, which has a half-life of $1.59 \times 10^{7} \mathrm{yr}$.

\subsection{Problem 2 - Flux of $5 \mathrm{~mm} / \mathrm{yr}$}

The input values of parameters for this problem are listed in Table 5 . The output for this problem consists of cumulative curies released to the accessible environment versus time for each radionuclide and each path.

TABLE 5

INPUT VALUES OF PARAMETERS FOR PROBLEM 2

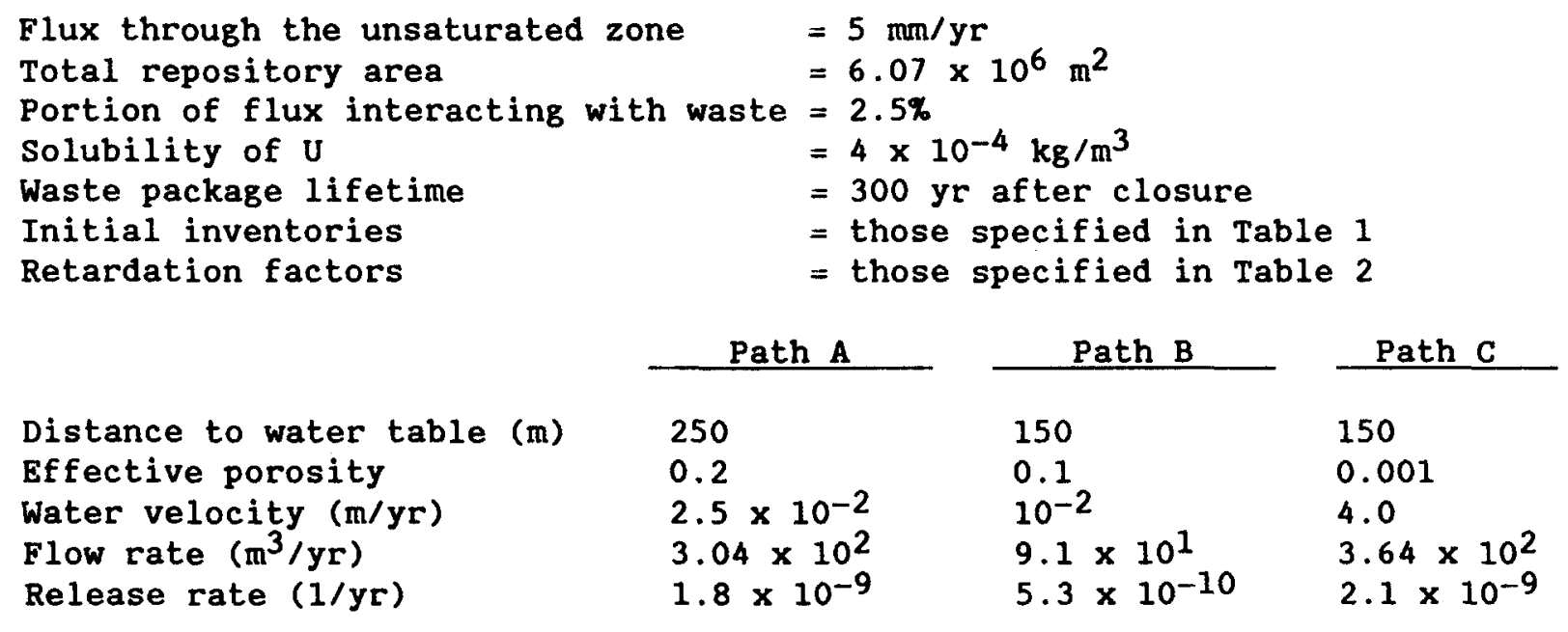

For a flux of $5 \mathrm{~mm} / \mathrm{yr}$, water flows through both the fractured pathways and the matrix pathways. The matrix of the vitric unit passes all the flux and all the water that flows through this pathway. Path A begins contributing to releases at the water table about $10,000 \mathrm{yr}$ after closure. Flow through the matrix of the Topopah Spring and zeolitic Calico Hills unit (Path B) is limited to a flux of $1 \mathrm{~mm} / \mathrm{yr}$, which is approximately the saturated, hydraulic 
conductivity of the matrix, and the flow reaches the water table about 30,000 yr after the closure. Portions of flux in excess of $1 \mathrm{~mm} / \mathrm{yr}$ that flow through the fractures in the Topopah Spring and Calico Hills units (Path $\mathrm{C}$ ) require only about $37.5 \mathrm{yr}$ to reach the water table. As a result, all the radionuclides from a repository overlying the zeolitic unit begin arriving at the water table shortly after the leaching starts from the waste packages $300 \mathrm{yr}$ after repository closure. Path $\mathrm{C}$ is thus the dominant contributor to the total releases.

\subsubsection{SPARTAN Solution}

Figure 3 shows the cumulative curies released to the accessible environment through Path A. Only three radionuclides, C-14, I-129, and Tc-99, are projected to reach the accessible environment in the first $100,000 \mathrm{yr}$ after repository closure. For Path $B$, only two nonretarded radionuclides (Figure 4) are projected to reach the accessible environment in the first $100,000 \mathrm{yr}$ after closure. The contributions of individual radionuclides to the cumulative curies released to the accessible environment through fractured pathways are shown in Figure 5 .

\section{3 .2 Analytical Solution}

The analytical solution of the one-dimensional transport equation for band release is quite involved [Harada et al. (1980)]. The calculation of analytical solutions for Problem 2 is accomplished by using the UCB NE-10.3 (Kajiwara, 1985) for analytical solution of one-dimensional transport with dispersion for three-member chains. A very small dispersion coefficient of $0.01 \mathrm{~m}^{2} / \mathrm{yr}$ was specified in the calculation. The computer code UCB NE-10.3 is the latest version of UCB NE-10 (Pigford, 1980) provided to SNL by T. H. Pigford. The current version inproves some numerical integration techniques of the original UCB NE-10.2 in computing analytical solutions (Kajiwara, 1985). UCB NE-10.3 gives the relative radionuclide concentration and discharge rate as a function of time and path length. The time-dependent release of cumulative curies across the boundary is obtained by integrating the discharge rate in curies. The computer program and input data for Problem 2 


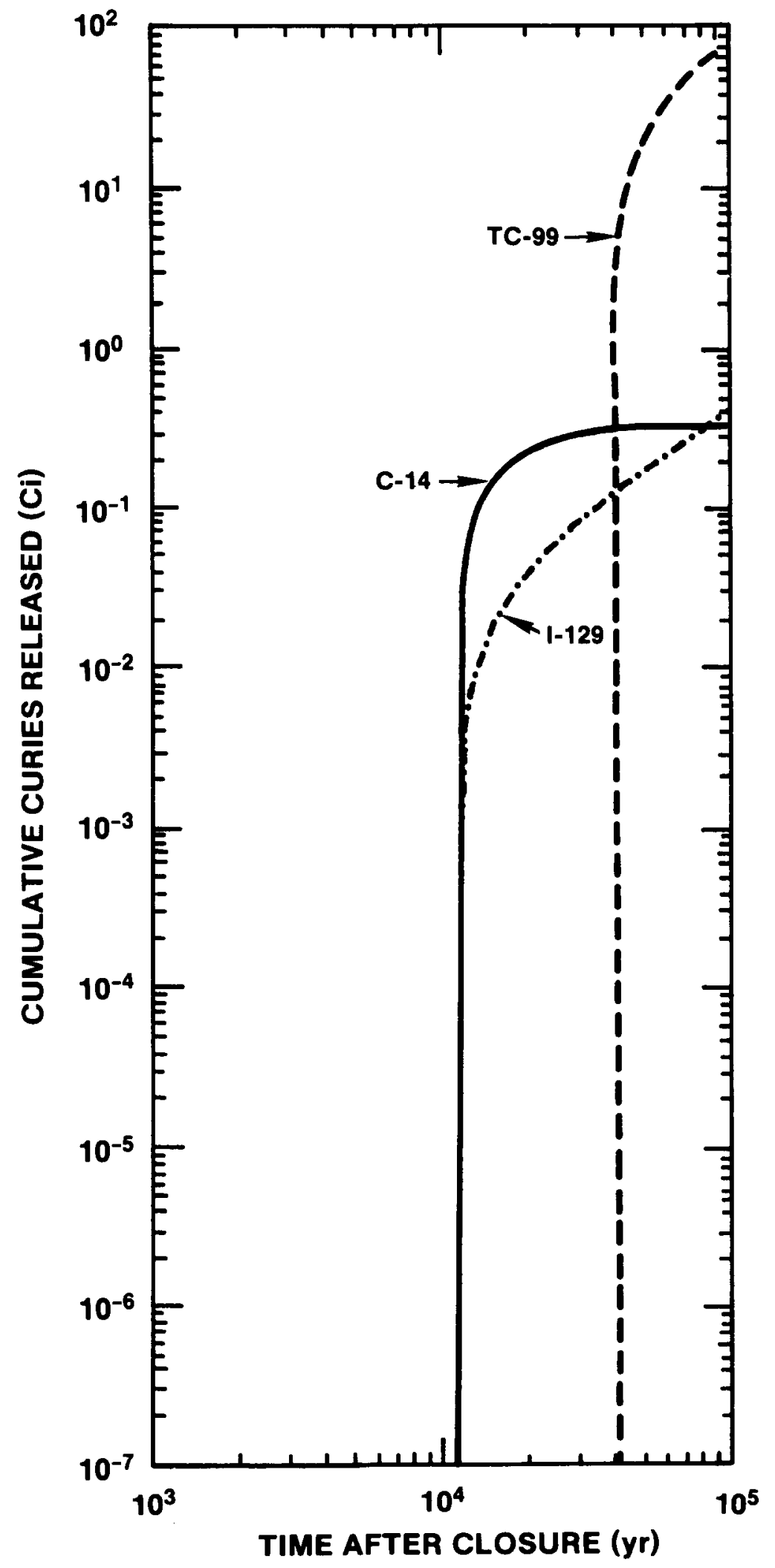

Figure 3. Cumulative Curies of Individual Radionuclides Reaching the Accessible Environment Through Path A in Problem 2 


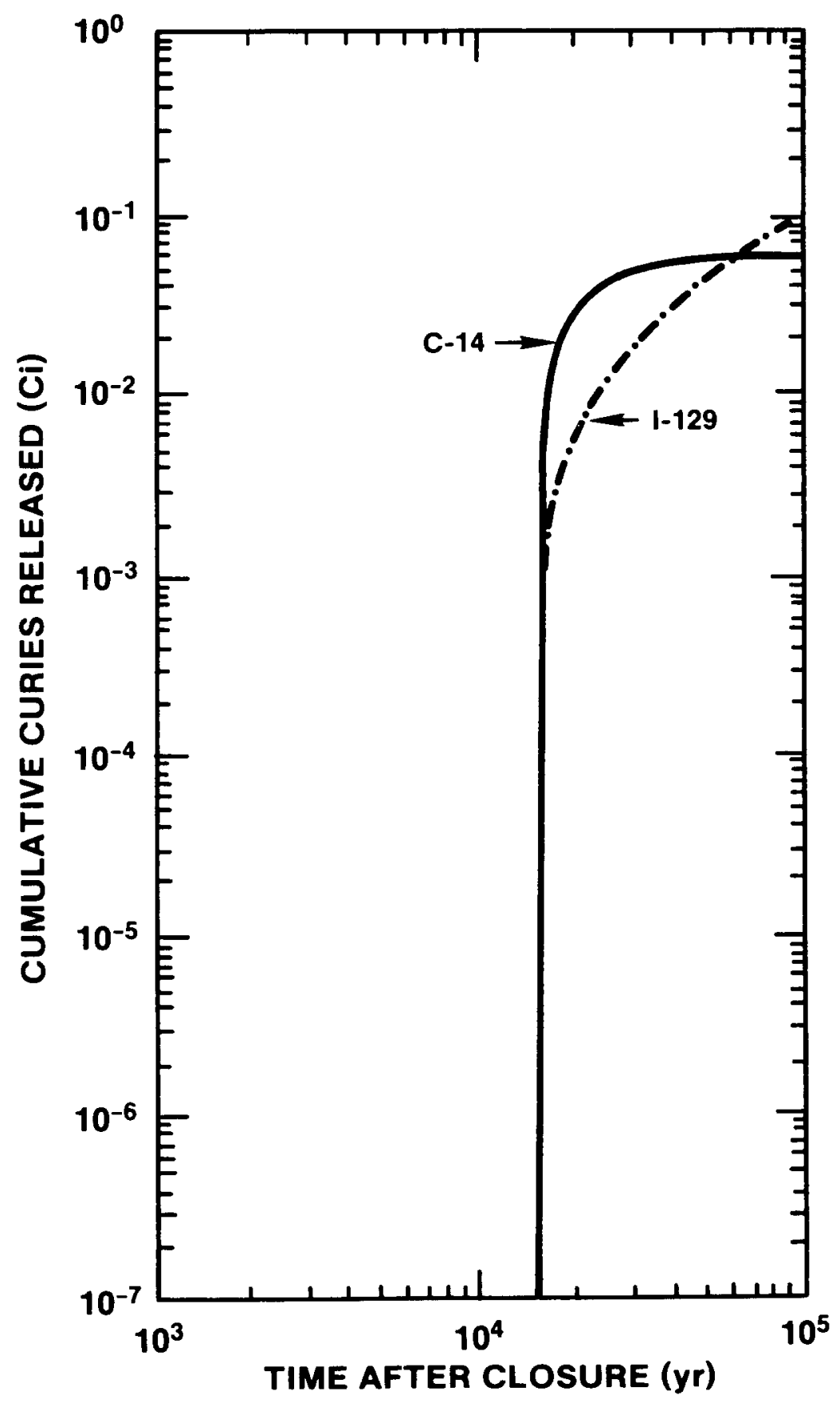

Figure 4. Cumulative Curies of Individual Radionuclides Reaching the Accessible Environment Through Path $B$ in Problem 2 


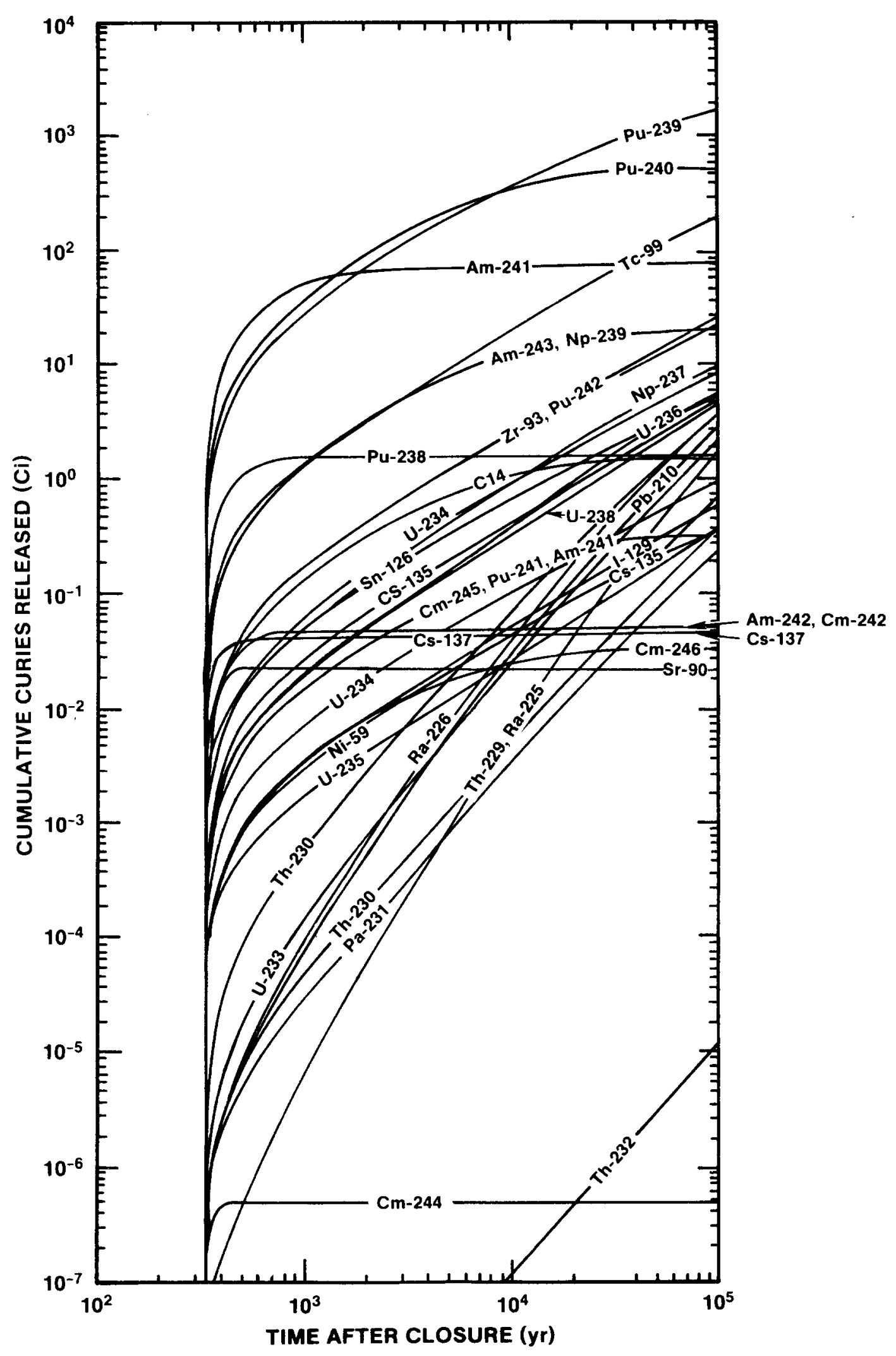

Figure 5. Cumulative Curies of Individual Radionuclides Reaching the Accessible Environment Through Path $C$ in Problem 2 
are listed in Appendix B. The computed values for cumulative curies released for individual radionuclides through each path are listed in Tables 6 through 8. Because the UCB NE-10.3 program only computes decay for radionuclide chains up to three member's, longer chains are broken down into component three-member chains in calculating the cumulative curies released. Radionuclides assumed to be in secular equilibrium in SPARTAN are not presented in Table 8 .

General solutions of the one-dimensional transport equation without dispersion have been shown by Pigford et al. (1980). However, a computer program, UCB NE-25, developed at Lawrence Berkeley Laboratory (LBL) to calculate the analytical solution for dispersionless transport was not available at the time that work was performed.

\subsubsection{Comparison of the Results}

The results from SPARTAN simulation and from analytical solutions (Tables 6 through 8) agree closely; in all cases, agreement is within 10\%, and for long-lived radionuclides agreement is even closer in most cases. A significant finding is that, for radionuclides with relatively short half-lives, the discrepancies are slightly larger, i.e., within 10 to $100 \%$. This greater discrepancy is caused by numerical approximation made in the integration of the curie release rate in SPARTAN. Even with a small value for dispersion, the effects of the dispersion seem to be important for long water flow time and for radionuclides with long half-lives. Although hydrodynamic dispersion is not included in SPARTAN, the execution time of SPARTAN is at least an order of magnitude faster than the calculation time of the analytical solution. Given the computing efficiency of SPARTAN, it may be prudent to enhance this model for use in probabilistic modeling if the a priori probability of scenarios and the statistical distribution of the parameters are available. 
TABLE 6

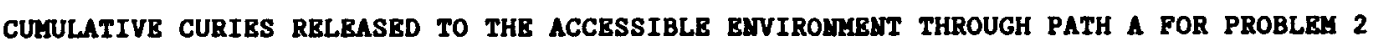

\begin{tabular}{|c|c|c|c|c|c|c|c|c|}
\hline \multirow{3}{*}{$\begin{array}{l}\text { Cumulative Curles } \\
\text { Released (Ci) }\end{array}$} & \multicolumn{8}{|c|}{ Time After Closure (yr) } \\
\hline & \multicolumn{2}{|r|}{$10^{4}$} & \multicolumn{2}{|c|}{$2 \times 10^{4}$} & \multicolumn{2}{|c|}{$5 \times 10^{4}$} & \multicolumn{2}{|c|}{$10^{5}$} \\
\hline & SPARTAN & Analytical $\star$ & SPARTAN & Analytical & SPARTAL & Analytical & SPARTAII & Analyticalћ \\
\hline$C-14$ & 0 & $1.47 \times 10^{-2}$ & $2.16 \times 10^{-1}$ & $2.17 \times 10^{-1}$ & $3.23 \times 10^{-1}$ & $3.51 \times 10^{-1}$ & $3.26 \times 10^{-1}$ & $3.55 \times 10^{-1}$ \\
\hline$I-129$ & 0 & $1.19 \times 10^{-3}$ & $3.73 \times 10^{-2}$ & $3.23 \times 10^{-2}$ & $1.62 \times 10^{-1}$ & $1.56 \times 10^{-1}$ & $3.72 \times 10^{-1}$ & $3.62 \times 10^{-1}$ \\
\hline Tc-99 & 0 & 0 & 0 & $3.79 \times 10^{-35}$ & $1.24 \times 10^{1}$ & $1.42 \times 10^{1}$ & $7.65 \times 10^{1}$ & $7.80 \times 10^{1}$ \\
\hline
\end{tabular}

*Calculated by UCB HE-10.3 with dispersion coefficient of $0.01 \mathrm{~m}^{2} / \mathrm{yr}$.

TABLE 7

CUIULATIVE CURIES RELEASEd TO THE ACCESSIBLE EUVIROMAGMT THROUGH PATH B FOR PROBLEE 2

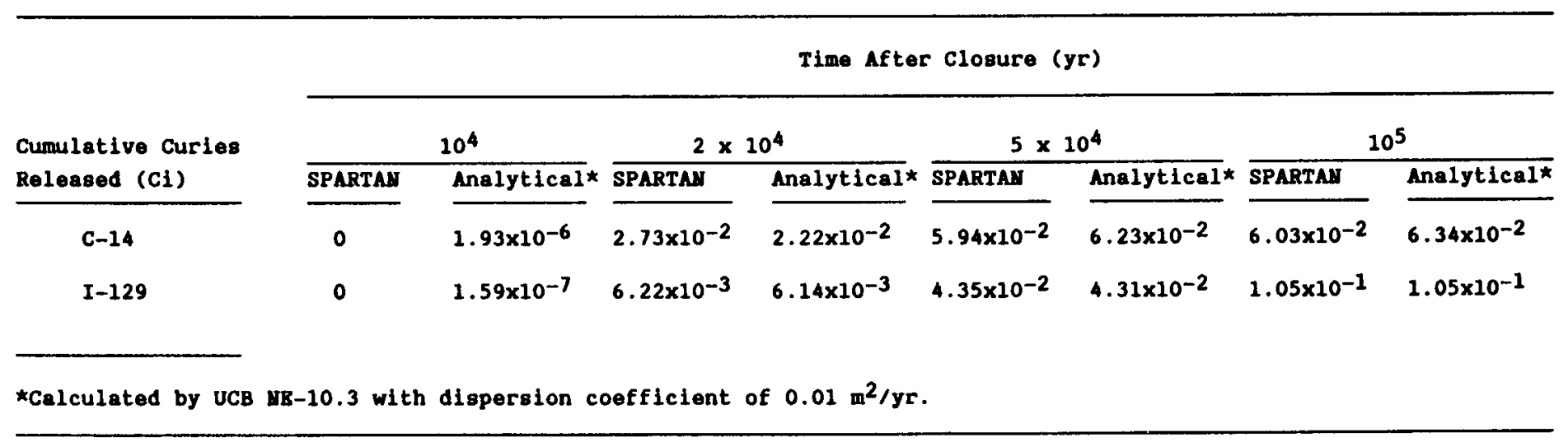


TABLE 8

CURULATIVE CURIES RELEASED TO THE ACCESSIBLE EAVIROMMEMT THROUGH PATH C FOR PROBLEM 2

\begin{tabular}{|c|c|c|c|c|c|c|c|c|}
\hline \multirow{2}{*}{$\begin{array}{l}\text { Cumulative Curies } \\
\text { Released (Ci) }\end{array}$} & \multicolumn{2}{|c|}{$10^{3}$} & \multicolumn{2}{|c|}{$5 \times 10^{3}$} & \multicolumn{2}{|c|}{$10^{4}$} & \multicolumn{2}{|c|}{$10^{5}$} \\
\hline & SPARTAH & Analytical* & SPARTAN & Analytical* & SPARTAN & Analytical* & SPARTAE & Analytical* \\
\hline C-14 & $1.82 \times 10^{-1}$ & $1.79 \times 10^{-1}$ & $7.28 \times 10^{1}$ & $7.45 \times 10^{-1}$ & $1.14 \times 1-0$ & $1.16 \times 10^{0}$ & $1.31 \times 10^{0}$ & $1.71 \times 10^{0}$ \\
\hline Tc-99 & $1.85 \times 10^{0}$ & $1.85 \times 10^{0}$ & $9.36 \times 10^{0}$ & $9.56 \times 10^{0}$ & $1.88 \times 10^{1}$ & $1.91 \times 10^{1}$ & $1.62 \times 10^{2}$ & $1.66 \times 10^{2}$ \\
\hline I-129 & $4.78 \times 10^{-3}$ & $4.70 \times 10^{-3}$ & $2.44 \times 10^{-2}$ & $2.45 \times 10^{-2}$ & $4.93 \times 10^{-2}$ & $4.92 \times 10^{-2}$ & $4.91 \times 10^{-1}$ & $4.93 \times 10^{-1}$ \\
\hline Mi-59 & $4.29 \times 10^{-3}$ & $4.24 \times 10^{-3}$ & $2.15 \times 10^{-2}$ & $2.17 \times 10^{-2}$ & $4.25 \times 10^{-2}$ & $4.27 \times 10^{-2}$ & $2.93 \times 10^{-1}$ & $2.99 \times 10^{-1}$ \\
\hline $\mathrm{Cg}-135$ & $3.89 \times 10^{-2}$ & $3.84 \times 10^{-2}$ & $1.99 \times 10^{-1}$ & $2.00 \times 10^{-1}$ & $4.01 \times 10^{-1}$ & $4.02 \times 10^{-1}$ & $3.97 \times 10^{0}$ & $4.00 \times 10^{0}$ \\
\hline $5 n-126$ & $6.86 \times 10^{-2}$ & $6.77 \times 10^{-2}$ & $3.45 \times 10^{-1}$ & $3.48 \times 10^{-1}$ & $6.85 \times 10^{-1}$ & $6.88 \times 10^{-1}$ & $5.07 \times 10^{0}$ & $5.16 \times 10^{0}$ \\
\hline $2 r-93$ & $2.43 \times 10^{-1}$ & $2.42 \times 10^{-1}$ & $1.25 \times 10^{0}$ & $1.26 \times 10^{0}$ & $2.53 \times 10^{0}$ & $2.53 \times 10^{0}$ & $2.44 \times 10^{1}$ & $2.46 \times 10^{1}$ \\
\hline Sr-90 & $2.31 \times 10^{-2}$ & $1.83 \times 10^{-2}$ & $2.31 \times 10^{-2}$ & $1.83 \times 10^{-2}$ & $2.31 \times 10^{-3}$ & $1.83 \times 10^{-2}$ & $2.31 \times 10^{-2}$ & $1.83 \times 10^{-2}$ \\
\hline C8-137 & $4.74 \times 10^{-2}$ & $3.81 \times 10^{-2}$ & $4.75 \times 10^{-2}$ & $3.81 \times 10^{-2}$ & $4.75 \times 10^{-2}$ & $3.81 \times 10^{-2}$ & $4.75 \times 10^{-3}$ & $3.81 \times 10^{-2}$ \\
\hline $\mathrm{Cm}-244$ & $5.01 \times 10^{-7}$ & $2.77 \times 10^{-7}$ & $5.01 \times 10^{-7}$ & $2.77 \times 10^{-7}$ & $5.01 \times 10^{-7}$ & $2.77 \times 10^{-7}$ & $5.01 \times 10^{-7}$ & $2.77 \times 10^{-7}$ \\
\hline $\mathrm{Pu}-240$ & $5.95 \times 10^{1}$ & $5.86 \times 10^{1}$ & $2.45 \times 10^{2}$ & $2.50 \times 10^{2}$ & $3.94 \times 10^{2}$ & $4.00 \times 10^{2}$ & $5.04 \times 10^{2}$ & $6.35 \times 10^{2}$ \\
\hline$U-236$ & $3.34 \times 10^{-2}$ & $3.27 \times 10^{-2}$ & $1.86 \times 10^{-1}$ & $1.85 \times 10^{-1}$ & $4.05 \times 10^{-1}$ & $4.01 \times 10^{-1}$ & $5.01 \times 10^{0}$ & $4.95 \times 10^{0}$ \\
\hline Th-232 & $1.46 \times 10^{-9}$ & $1.40 \times 10^{-9}$ & $2.69 \times 10^{-8}$ & $2.53 \times 10^{-8}$ & $1.06 \times 10^{-7}$ & $1.01 \times 10^{-7}$ & $1.26 \times 10^{-5}$ & $1.20 \times 10^{-5}$ \\
\hline$C m-245$ & $2.43 \times 10^{-2}$ & $2.40 \times 10^{-2}$ & $1.07 \times 10^{-1}$ & $1.08 \times 10^{-1}$ & $1.82 \times 10^{-1}$ & $1.84 \times 10^{-1}$ & $3.05 \times 10^{-1}$ & $3.59 \times 10^{-1}$ \\
\hline$A m-241$ & $6.65 \times 10^{1}$ & $6.58 \times 10^{1}$ & $6.93 \times 10^{1}$ & $9.01 \times 10^{1}$ & $6.95 \times 10^{1}$ & $9.02 \times 10^{1}$ & $6.95 \times 10^{1}$ & $9.02 \times 10^{1}$ \\
\hline Mp-237 & $8.05 \times 10^{-2}$ & $7.45 \times 10^{-2}$ & $4.70 \times 10^{-1}$ & $4.36 \times 10^{-1}$ & $9.63 \times 10^{-1}$ & $8.92 \times 10^{-1}$ & $9.65 \times 10^{0}$ & $9.00 \times 10^{0}$ \\
\hline$U-233$ & $2.66 \times 10^{-4}$ & $2.45 \times 10^{-4}$ & $5.62 \times 10^{-4}$ & $4.98 \times 10^{-3}$ & $2.17 \times 10^{-2}$ & $1.95 \times 10^{-2}$ & $1.89 \times 10^{0}$ & $1.69 \times 10^{0}$ \\
\hline Th-229 & $1.13 \times 10^{-5}$ & $7.65 \times 10^{-6}$ & $4.60 \times 10^{-5}$ & $4.31 \times 10^{-4}$ & $5.69 \times 10^{-3}$ & $2.76 \times 10^{-3}$ & $1.58 \times 10^{0}$ & $7.09 \times 10^{-1}$ \\
\hline $\mathrm{Cm}-246$ & $4.53 \times 10^{-3}$ & $4.46 \times 10^{-3}$ & $1.80 \times 10^{-2}$ & $1.84 \times 10^{-2}$ & $2.78 \times 10^{-2}$ & $2.83 \times 10^{-2}$ & $3.11 \times 10^{-2}$ & $4.11 \times 10^{-2}$ \\
\hline $\mathrm{Pu}-242$ & $2.30 \times 10^{-1}$ & $2.28 \times 10^{-1}$ & $1.17 \times 10^{0}$ & $1.18 \times 10^{0}$ & $2.36 \times 10^{0}$ & $2.36 \times 10^{0}$ & $2.17 \times 10^{1}$ & $2.19 \times 10^{1}$ \\
\hline$U-238$ & $4.62 \times 10^{-2}$ & $4.56 \times 10^{-2}$ & $2.36 \times 10^{-1}$ & $2.37 \times 10^{-1}$ & $4.77 \times 10^{-1}$ & $4.77 \times 10^{-1}$ & $4.76 \times 10^{0}$ & $4.79 \times 10^{0}$ \\
\hline$A m-242$ & $5.25 \times 10^{-2}$ & $5.22 \times 10^{-2}$ & $5.25 \times 10^{-2}$ & $5.38 \times 10^{-2}$ & $5.25 \times 10^{-2}$ & $5.38 \times 10^{-2}$ & $5.25 \times 10^{-2}$ & $5.38 \times 10^{-2}$ \\
\hline Pu-238 & $1.59 \times 10^{0}$ & $1.41 \times 10^{0}$ & $1.58 \times 10^{0}$ & $1.42 \times 10^{0}$ & $1.59 \times 10^{0}$ & $1.42 \times 10^{0}$ & $1.59 \times 10^{0}$ & $1.42 \times 10^{0}$ \\
\hline$U-234$ & $1.13 \times 10^{-1}$ & $1.01 \times 10^{-1}$ & $5.77 \times 10^{-1}$ & $5.26 \times 10^{-1}$ & $1.15 \times 10^{0}$ & $1.05 \times 10^{0}$ & $1.02 \times 10^{1}$ & $9.33 \times 10^{0}$ \\
\hline Th-230 & $1.07 \times 10^{-3}$ & $9.56 \times 10^{-4}$ & $1.98 \times 10^{-2}$ & $1.72 \times 10^{-2}$ & $7.27 \times 10^{-2}$ & $6.46 \times 10^{-2}$ & $5.18 \times 10^{0}$ & $4.61 \times 10^{0}$ \\
\hline$R a-226$ & $1.88 \times 10^{-4}$ & $7.26 \times 10^{-5}$ & $9.62 \times 10^{-3}$ & $3.26 \times 10^{-3}$ & $4.87 \times 10^{-2}$ & $1.66 \times 10^{-2}$ & $5.07 \times 10^{0}$ & $1.79 \times 10^{0}$ \\
\hline$A m-243$ & $1.87 \times 10^{0}$ & $1.85 \times 10^{0}$ & $8.00 \times 10^{0}$ & $8.16 \times 10^{0}$ & $1.33 \times 10^{1}$ & $1.35 \times 10^{1}$ & $1.97 \times 10^{1}$ & $2.39 \times 10^{1}$ \\
\hline Pu-239 & $4.08 \times 10^{1}$ & $4.03 \times 10^{1}$ & $1.97 \times 10^{2}$ & $1.99 \times 10^{2}$ & $3.72 \times 10^{2}$ & $3.75 \times 10^{2}$ & $1.37 \times 10^{3}$ & $1.45 \times 10^{3}$ \\
\hline U-235 & $2.35 \times 10^{-3}$ & $2.31 \times 10^{-3}$ & $1.24 \times 10^{-2}$ & $1.25 \times 10^{-2}$ & $2.60 \times 10^{-2}$ & $2.59 \times 10^{-2}$ & $3.43 \times 10^{-1}$ & $3.41 \times 10^{-1}$ \\
\hline $\mathrm{Pa}-231$ & $4.48 \times 10^{-5}$ & $6.99 \times 10^{-4}$ & $7.66 \times 10^{-4}$ & $4.42 \times 10^{-3}$ & $2.81 \times 10^{-3}$ & $9.75 \times 10^{-3}$ & $2.01 \times 10^{-1}$ & $2.25 \times 10^{-1}$ \\
\hline
\end{tabular}

*Calculated by UCB MB-10.3 with dispersion coefficient of $0.01 \mathrm{~m}^{2} / \mathrm{yr}$. 
A computer model that provides a simple performance assessment of radionuclide transport (SPARTAN) has been developed to simulate the postclosure performance of the Yucca Mountain repository site. The computer model presented in the report is a useful tool for the systems studies required for the NNWSI environmental assessment document (DOE, 1984). The test problems presented in this report show good agreement between the SPARTAN simulations and the analytical solutions. Thus, for a simple systems performance assessment, SPAKTAN can be used with a high degree of confidence for the types of problems addressed in this report. The computation time required by SPARTAN is low enough that its enhancement for probabilistic assessments of repository performance may be warranted. 


\section{REFERENCES}

Bateman, H., 1910, "The Solution of a System of Differential Equations Occurring in the Theory of Radioactive Transformations," Proc. Cambridge Phil. Soc., 15, pp. 423-427.

Burkholder, H. C., 1976, "Methods and Data for Predicting Nuclide Migration in Geologic Media, Proc. Intern. Symp. Management of Wastes from LWR Fuel Cycle, CONF-76-0701, Pp. 658-666, Oak Ridge National Laboratory, Oak Ridge, TN.

Chambré, P. L., T. H. Pigford, A. Fujita, T. Kanki, A. Kobayashi, H. Lung, D. Ting, Y. Sato, and S. J. Zavosky, October 1982, "Analytical Performance Models for Geologic Repositories," Rpt. LBL-14842, Lawrence Berkeley Laboratory, Berkeley, CA.

Daniels, W. R., et a1., 1982, "Summary Report on the Geochemistry of Yucca Mountain and Environs," Rpt. LA 9328-MS, 364 pp., Los Alamos National Laboratory, Los Alamos, NM.

Daniels, W. R., et a1., 1983, "Research and Development Related to the Nevada Nuclear Waste Storage Investigations July 1 - September 30, 1983," Rpt. LA-9755-PR, Los Alamos National Laboratory, Los Alamos, NM.

DOE (U.S. Department of Energy), 1979, "Technology for Commercial Radioactive Waste Management," Rpt. DOE/ET-0028, Vol. 1, U.S. Department of Energy, Washington D.C.

DOE (U.S. Department of Energy), 1984, "Draft Environmental Assessment, Yucca Mountain Site, Nevada Research and Development Area, Nevada, DOE/RW-0012, U.S. Department of Energy, Washington D.C.

EPA (U.S. Environmental Protection Agency), April 17, 1984, "Environmental Radiation Protection Standards for Management and Disposal of Spent Nuclear Fuel, High-Level and Transuranic Radioactive Wastes," Proposed Rule 40 CFR 191, Working Draft 4, 21 pp., U.S. Environmental Protection Agency, Washington D.C.

Freeze, R. A. and J. A. Cherry, 1973, Groundwater, 604 pp., Prentice-Hall, Englewood Cliffs, NJ.

Harada, M., P. L. Cambré, M. Foglia, K. Higashi, F. Iwamoto, D. Leung, T. H. Pigford and D. Ting, February 1980, "Migration of Radionuclides Through Sorbing Media Analytical Solutions-I," Rpt. LBL-10500, Lawrence Berkeley Laboratory, Berkeley, CA.

Kajiwara, S., 1985, "Comparison of Calculation Results Among Different UCB NE-10 Codes," Lawrence Berkeley Laboratory, Berkeley, CA.

National Research Counci1, 1983, "A Study of the Isolation System for Geologic Disposal of Radioactive Wastes," 345 pp. , Waste Isolation Systems Panel (T. H. Pigford, Chm.), National Academy Press, Washington D.C. 
NRC (U.S. Nuclear Regulatory Commission), June 21, 1983, "Disposal of High-Level Nuclear Wastes in Geologic Repositories: Technical Criteria, Final Rule 10 CFR 60," Federal Register, Vol. 48, n. 120, pp. 28194-28229, U.S. Nuclear Regulatory Commission.

Pigford, T. H., P. L. Chambré, M. Albert, M. Foglia, M. Harada, F. Iwamoto, T. Kanki, D. Leung, S. Masuda, S. Muraolea, and D. Ting, October 1980, "Migration of Radionuclides Through Sorbing Media Analytical Solutions-II," Rpt. LBL-11616, Lawrence Berkeley Laboratory, Berkeley, CA.

Sinnock, S., Y. T. Lin, and J. P. Brannen, 1984, "Preliminary Bounds on the Expected Postclosure Performance of the Yucca Mountain Repository Site, Southern Nevada, Rpt. SAND 84-1492, Sandia National Laboratories, Albuquerque, NM. 


\section{APPENDIX A}

\section{COMPUTER SOURCE LISTINGS OF SPARTAN}

This section contains a detailed computer listing for SPARTAN. The data were built into the program as data statements. SPARTAN is written in FORTRAN and is compiled and executed in a CRAY computer.

PROGRAM COMPARE

DIMENSION RTCUR $(3,100,5,14)$, RTCURS $(3,100,2,4), \operatorname{RATIO}(5,14)$

DEE (100), SRC (100), DISCI (100), ERM (100), TEAC (100), YR (100)

DIMENSION REC (10), TT (3,10), VS (3,10), EL (3.10,3)

$\therefore \operatorname{DR}(3,10,3), \operatorname{TL}(3,10,3), \operatorname{FR}(3,10,3)$

DIMENSION AL $(5,14)$, NEC (14), CONI $(5,14), \operatorname{CONN}(5,14), H L S(2,4)$

*ALS $(2,4)$, SPA $\{5,14)$, AM $(5,14), \operatorname{RNA}\{2,4), \operatorname{RCH}(5,14)$, CONIS $(2,4)$

DIMENSION ALP $(2,4)$, CURS $(2,4)$, CUMS $(2,4)$, PAR $(2,4), \operatorname{NECS}(4)$,

*CUR $(5,14)$, SPAS $(2,4), \operatorname{PAC}(2,4)$

DIMENSION RL $(5,14), \operatorname{RLS}(2,4), \operatorname{CIR}(5,14), \operatorname{CIRS}(2,4)$

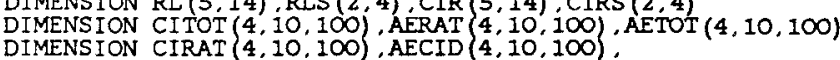

*RC $(100,5,14)$

DIMENSION DIS $(3,100,5,14), \operatorname{AGIN}(100,5,14)$, RDE $(3,5,14)$

$\star \operatorname{RDES}(3,2,4)$, AGINS $(100,2,4), \operatorname{RCS}(10,2,4)$

- SUR $(4,100,5,14)$, SURS $(4,100,2,4)$, SUC $(4,100,5,14)$, SUCS $(4,100,2,4)$

DIMENSION TM21 (14), TM31 (14), TM41 (14), TM51 (14), TM32 (14), TM42 (14). *TM52 (14), TM53 (14), TM54 (14), TM43 (14), CONIW $(5,14), \operatorname{CONNW}(5,14)$

-DCON $(5,14)$

DIMENSION EP (3), ERA (3), ERE (3) , DI (3) , FLUX (3,10) .NP (10)

DATA (EP (I) $I=1,3) 10.2,0.1,0.001 /$

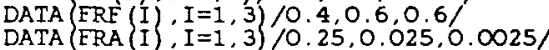

DATA ERA (I) $I=1,3) / 0.25,0.025,0.0025$

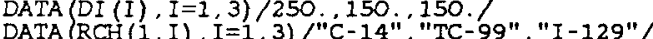

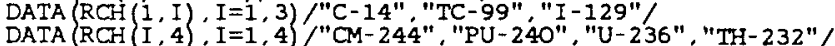

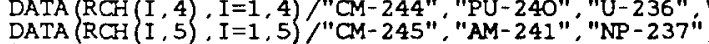

DATA $\mathrm{RCH}, 233$ " I, 5 ,, $\mathrm{I}=1$,

DATA RCH (I 14), I=1,5)/"CM-246", "PU-242",

*"U-238", "TH-230*", "RA-226*"

"U-238", TH-230"", "RA-226*"/,
DAAA (RCH (I, 6), I=1, 5)/"AM-242", "PU-238", "U-234".
"TH-230". "RA-226"/

DATA (RCH (I, 7) , I=1, 4) /"AM-243". "PU-239", "U-235" , "PA-231"/

DATA (RCH $\{1,1\}, I=8,13) /$ "NI-59","

"SR-90" "CS-137",

DATA (AM $(1 . I) . I=1,3) / 14.99,129 . /$

DATA AM $\left\{\begin{array}{l}1 \\ \text { DAT }\end{array}, \mathrm{I}=1,4\right\} / 244,240,236,232,1$

DATA AM $(1,5\}, I=1,5\} / 245,241.237,233 \ldots 229.1$

DATA AM $\{I, 6), I=1,5) / 242 \ldots 238,234,230.226 . /$

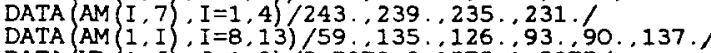

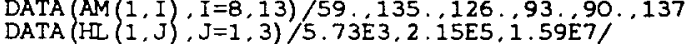

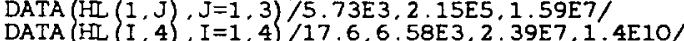

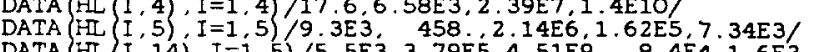

DATA HL $(1,14), I=1,5) / 5,5 E 3,3.79 E 5,4.51 E 9,8,4 E 4,1.6 E 3 /$

DATA (HL $\{, 6), I=1,5) / 152,, 86,2,4755,8,4 E 4,1.6 E 3 /$

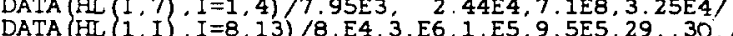

DATA (HL $(1, I), I=8,13) / 8 . E 4,3$. E6 $, 1, E 5,9.5 E 5,29,30 . /$

DA'TA (NEC (I) $I=1,14) / 1,1,1,4,5,5,4,1,1,1,1$

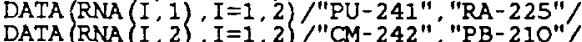

DATA (RNA $\{I, 4), I=1,2\} / " \mathrm{U}-234 * ", " \mathrm{~PB}-210 * 1 /$

DATA RNA $\{1,3\}$ '"NP-239"'

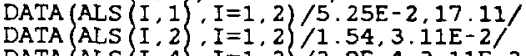

DATA ALS $\{1,4, \quad I=1,2) / 2.8 E-4,3.11 E-2 /$

DATA (NECS (I) $I=1,4) / 2,2,1,2 /$

DATA SPAS I $1=1,4) / 2,2.1,2 / 3,92 \mathrm{E} 4$

DATA SPAS $\{I, 2\}, I=1,2\} / 3.32 \mathrm{E} 3,7.63 \mathrm{E} 1$

DATA (SPAS I I $4, I=1,2) / 6.18 \mathrm{E}-3,7.63 \mathrm{E} 1 /$

DATA (RL (1, I $;, I=1,3) / 7000$. , 7.OE5, 7.OE4/

$\operatorname{ccc}$

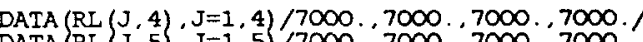

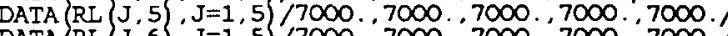

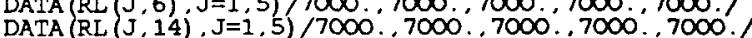

DATA RL $(J, 14), J=1,5) / 7000,7000,7000,7000 \%$

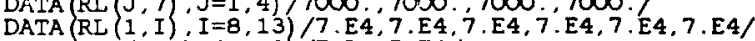

DATA (RLS $(I, 1), I=1,2) / 7, E 4,7, E 4 /$

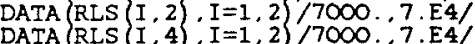

DATA RLS $(I, 4), I=1,2$

DATA (RDE $(1,1, I), I=1,3) / 1 \ldots 4 \ldots 1$.

DATA RDE $(1, I, 4), I=1,4) / 1800,640 \ldots 19,, 5800$.

DATA (RDE (I. I, 5), $I=1,5) / 1800, \ldots, 1800 \ldots, 71 \ldots 19 \ldots, 5800$.

DATA (RDE $(1, I, 14), I=1,5) / 1800,640,19,5800,9000 . /$

DATA (RDF $(1, I, 6), I=1,5) / 1800 \ldots, 640 \ldots, 19,5800 \ldots 9000$.

DATA RDF $\{1, I, 7, \quad I=1,4) / 1800,640 \ldots 19,640 . /$

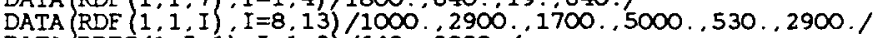

DATA RDFS (1, I. 1 ) $I=1,2\} 1640 \ldots 9000 \%$

DATA (RDES $\{1, I, 2\}: I=1,2\} / 1800,51 . /$

DATA (RDES $\{1, I, 4), I=1,2) / 19 ., 51.1$

DATA RDFS $(1,1,3) / 71 . \%$

DATA (RDF (2, $1, I) \quad I=1,3) / 1,7,1 /$

DATA RDF $(2, I, 4) \quad I=1,4) / 3600,1300 \ldots, 37,12000,1$

DATA RDE $(2, I, 5), I=1,5) / 3600,3600 \ldots, 140$, , $37 \ldots, 12000$.

DATA RDF $(2, I, 14), I=1,5) / 3600,1300,37,12000,18000$.

DATA RDE $\{2, I, 6) . I=1,5) / 3600 \ldots, 1300 \ldots 37 \ldots, 12000 \ldots, 18000 . /$

DATA RDE $\{2, I, I\}: I=8,13\} / 2000 \%, 5800,3400,10000,1100,5800$. $/$

DATA RDF $(2, I, 1), I=1,2,1300,18000.1$

DATA RDES $(2, I, 2), I=1,2\} / 3600,100$.

DATA (RDFS $2, I, 4), I=1,2\} / 37,100 . /$

DATA RDFS $(2,1,3) / 140$.

$\operatorname{DATA}(\operatorname{RDF}(3,1,1), I=1,3) / 1,1,1.1$

DATA RDF $(3, I, 4), I=1,4) / 1,1,1,1,1$

DATA RDE $(3, I, 5), I=1,5) / 1,1,1,0,1,0,1,1 /$

DATA (RDE $(3, I, 14), I=1,5) / 1,1,1,0,1,1,1.2 /$

DATA RDE $(3, I, 6), I=1,5) / 1.0,1,0,1.0,1.1,1.2 /$

DATA RDF $\{3, I, 7\}, I=1,4\} 1,1,1,0,1.1$

DATA RDE $3,1, I\}, I=8,13\}, 1,1,1,1,1,1,1,1$

DATA RDES $\{3, I, 1\}, I=1,2\} 1,1,2)$

DATA RDES $\{3,1,2\}, 1=1,2\} 1,1,1,1$

DATA (RDES $3,1,4\}, 1=1,2\} 1,0,1.0 /$

DATA RDES $\{3,1,3\} 1,1.0 \%$

DOE-28-10

DATA (CONI ( 1, I) $I=1,3) / 2.2 E 4,5,35 E 7,1,33 E 7 /$

DATA CONI I, 4 ) $I=1,4) / 7.57 \mathrm{E} 5,1.39 \mathrm{E} 8,2.43 \mathrm{E} 8,70$.

DATA (CONI I, $1=1,5) / 8.03 E 4,3.46 \mathrm{E} 7,3.08 \mathrm{E} 7,2.8 \mathrm{E} 2,9.2 \mathrm{E}-3 /$

DATA (CONI 1, 14) I I=1,5)/9. 28E3, 2.87E7,6.73E10, 1.E-8, 1.E-8/

DATA (CONI $(1,6), I=1,5) / 7.2 \mathrm{E} 4,8.0 \mathrm{E}+6,8.38 \mathrm{E} 5,1.48 \mathrm{E} 1,5.24 \mathrm{E}-4 /$

DATA CONI I , 7 , I=1, 4) $/ 5.30 \mathrm{E} 6,3.31 \mathrm{E} 8,5.23 \mathrm{~EB}, 8.23$

DATA (CONI $(1, I), I=8,13) / 2.77 E 4,2$. 14E7, $1.18 E 6,2.95 E 7,2.65 E 7$

$* 6.03 E 7 /$

DATA (CONIS $(I, 1), I=1,2) / 4,3 E 7,1.45 E-7 /$

DATA. (CONIS $(I, 2), I=1,2) / 1.79 \mathrm{E} 2,6.42 \mathrm{E}-5 /$

DATA CONIS $I, 4\}, I=1,2\} / 1$.E-8, 1 .E -8

DATA CONIS $(1,3) / 4.21$

CCC DOE-28-100O

DATA (CONI ( 1 , I) $, I=1,3) / 1.89 E 4,5.35 E 7,1.33 E 7 / C O N I$

DATA (CONI $\left.\left(\begin{array}{l}1 \\ \text { DATA }\end{array}\right) \cdot I=1,3\right) / 1,89 E 4,5 \cdot 35 E 7,1,33 E 7 / C O N I$

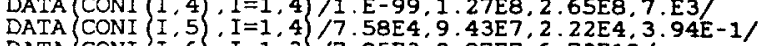

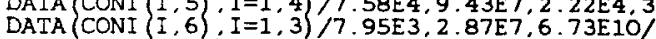

DATA CONI I 14 ) $, I=1,4) / 9.06 \mathrm{E} 6,2,16 \mathrm{E} 4,70.85,0.921$

DATA (CONI I . 14) $I=1,4) / 9$. O6E $6,2.16 E 4,70.85,0.92 /$

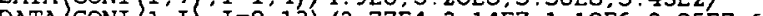

DATA (CONI (1. I) , I=8,13)/2.77E4,2 . 14E7, 1. 18E6, 2. 95E7, 6.64E-4

DATA (CONIS $(I, 1), I=1,3) / 1.06 E 2,1.79 E 7,1.89 E-3 /$ 
DATA (CONIS $(I, 2), I=1,3) / 7.92 E 2,1.96,4.4 E 3 /$ DATA CONIS
NCTNS $=14$

NNECS $=4$

IPR INT $=1$
IRATE $=0$

IRATE $=0$

$N L=3$
$I V=3$

C IV=1

IV $=2$.

$C 2=3.1558 \mathrm{E} 7$

$C 3=.693147$

$\mathrm{C} 5=1$.

$\mathrm{SL}=4 . \mathrm{E}-4$
$\mathrm{UI}=6.7967 \mathrm{E} 7$

DO 2 I=1, NCHNS

$\mathrm{N}=\mathrm{NEC}$ (I)

AL $(\mathrm{J}, \mathrm{I})=\mathrm{C}=\mathrm{C} / \mathrm{HL}(\mathrm{J}, \mathrm{I})$

C4=HL (J I I) C 22

CONTINUE

$N E=2$

$\mathrm{N}=200$
TOT $=0$.

DO $18 \mathrm{I}=1, \mathrm{NT}$

$18 \mathrm{YR}(\mathrm{I})=\mathrm{TOT}$

$\mathrm{YO}(\mathrm{I})=\mathrm{TOT}, \mathrm{T}=1 . \mathrm{NF}$

C $\quad \operatorname{REC}(I)=I * 0.0005$

IE $(I, E Q .1)$ REC $\{I\}=0.0005$

IELUX $(1$, I I $)=R E C\}$ I

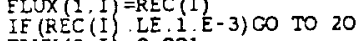

$\operatorname{ELUX}(2, I)=0 . \infty 1$

20) $\quad \operatorname{FLUX}(2, I)=\operatorname{REC}(I)$

$\operatorname{NP}(I)=2$

$\therefore \quad \operatorname{FLUX}(3, I)=\operatorname{REC}(\mathrm{I})-\operatorname{FLUX}(2, I)=3$

if $\quad \stackrel{N L}{D}=\frac{N P}{22}(I)=1, N L$

$\quad \operatorname{VS}(\mathrm{L}, \mathrm{I})=\mathrm{FLUX}(\mathrm{L}, \mathrm{I}) / \mathrm{EP}(\mathrm{L})$
$\operatorname{TT}(\mathrm{L}, \mathrm{I})=\mathrm{DI}(\mathrm{L}) / \mathrm{NS}(\mathrm{L}, \mathrm{I})+2000$.
$\mathrm{TT}(\mathrm{L})=\mathrm{DI}(\mathrm{L}) / \mathrm{NS}(\mathrm{L}, \mathrm{I})$

$\operatorname{TT}(L, I)=D I(L) / N S(L, I)$

DO 22 IC=1,3 $*$ SUX (L, I) *ERA (IC) •ERF (L)

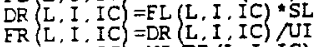

22 TL (L I IC) $=U$ II $/ \mathrm{R}$ (L.IIC)

CONTINUE

Do $24 \mathrm{~L}=1,3$

PRIN 24 I

DRINT 10I, REC (I), FLUX (L, I) , VS (L, I) , TT (L, I) , FL (L, I , 1)

- FL (L, I, 2) FL L i 1,3$)$

$24 \operatorname{ELUX}(\mathrm{L}, \mathrm{I})=1000$. $\mathrm{FLUX}(\mathrm{L}, \mathrm{I})$

DO 4 I $=1$, NCHNS

$\mathrm{N}=$ NEC (I) $\mathrm{IF}$ To 3

$\operatorname{TM} 21(I)=1 . /(\operatorname{AL}(2, I)-A L(1, I))$

TMB.

$\operatorname{MM} 31(I)=1 . /(A \mathrm{AL}(3, \mathrm{I})-\mathrm{AL}(1, \mathrm{I})\}$

TE (N.EQ.3) 00 TO 10

TM41 $(I)=1 . /$ (AL $(4, I)$-AL $(1, I)$

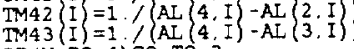

IE (N.EQ 4) CO TO 3

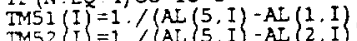

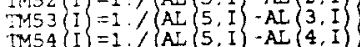

TMS4 I I $=$

CONTINUE

$\operatorname{ALP}(1,1)=\operatorname{AL}(1.5) / A L S(1.1)$

ALP $\{2,1\}=$ AL $(5,5)$ ALS $(2,1)$

ALP $\{, 2\}=A L, 5,6$ ALS 12,2

ALP $\{1,4\{=A L(3,14) / A L S(1,4)$

ALP $\{2,4)=A L(5,14) / A L S(2$.

IF IV. EQ. 1) DTT $=50$.

IE TIV EQ. 3) DTT=1050. NEC, CONI, TM21, TM31, TM41, TM32, TM42, TM43, CALL BAT (NCANS, AL, DTT, NEC, CC

TMTCI $=0$.

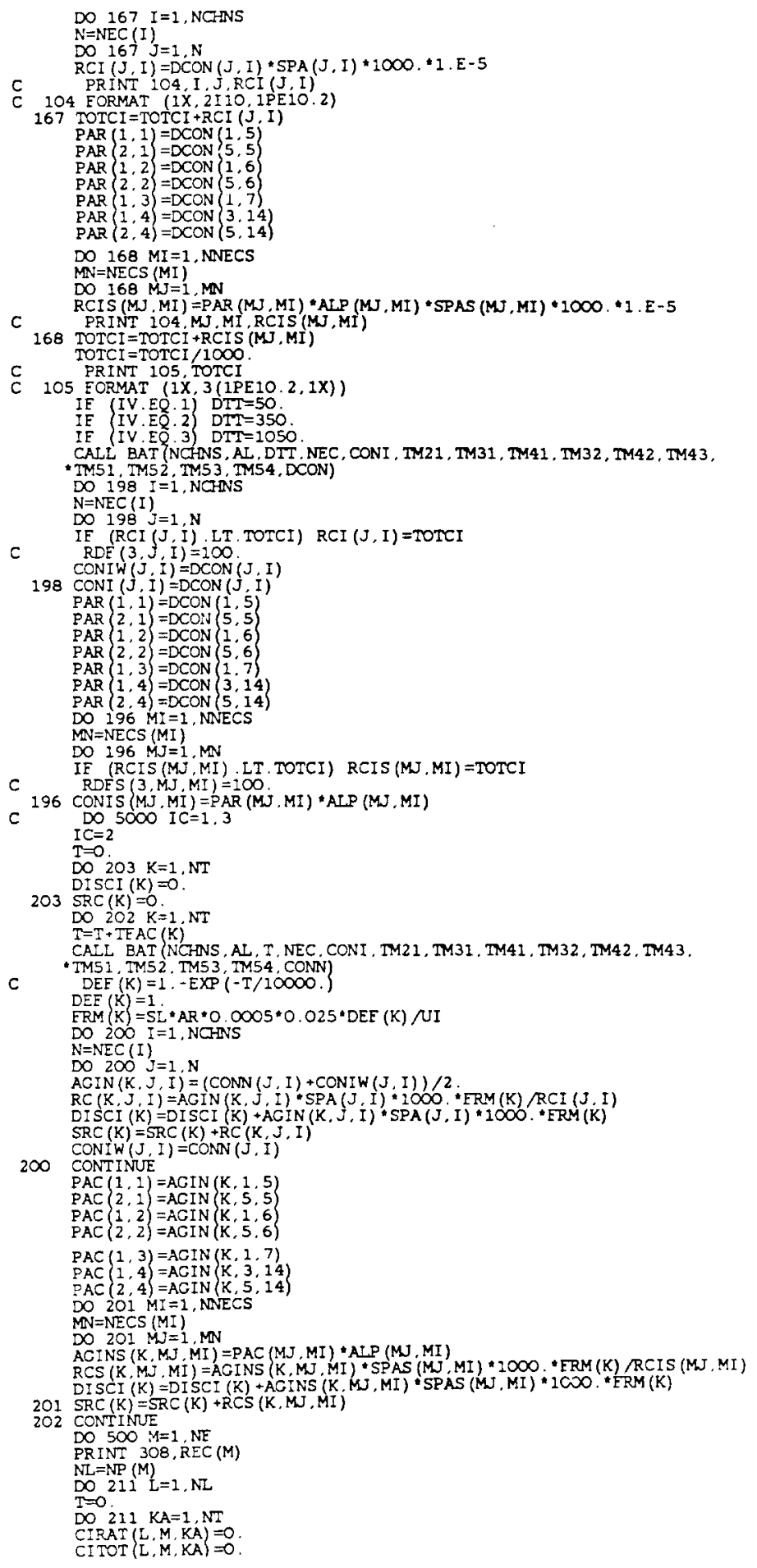




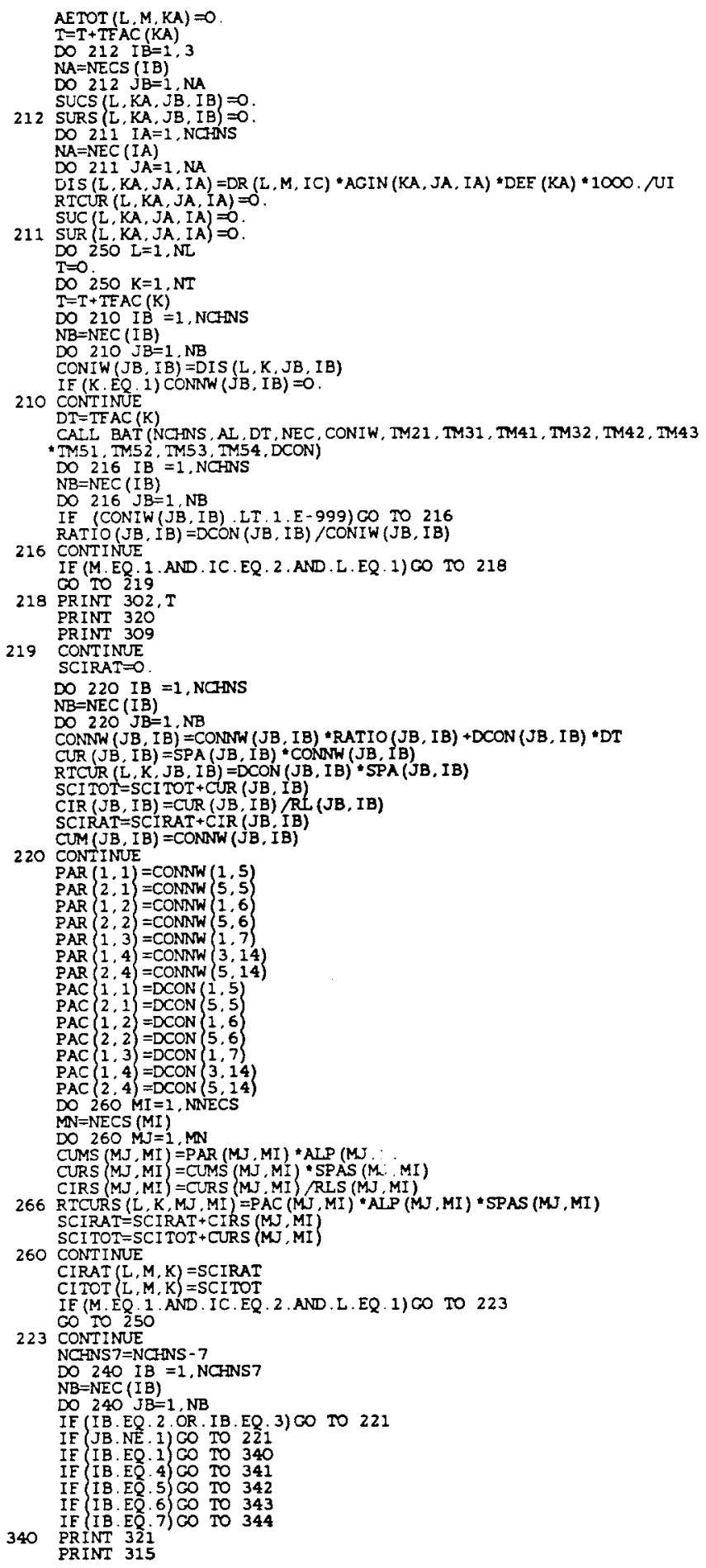

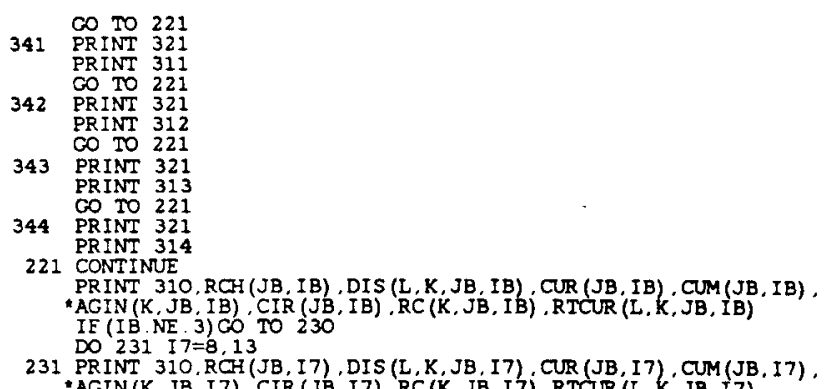

231 PRINT $310, \mathrm{RCH}$ (JB, I 7), DIS (L, K, JB,I7), CUR (JB,I7) , CUM (JB, I7) .

$230^{\circ}$ ACIN (K, JB,

$$
\begin{aligned}
& \text { IF IB.EQ. 5) CO TO } 5 \\
& \text { IF (IB.EQ.7) } 60 \text { TO } 7
\end{aligned}
$$

5 CO TO $(8,224,224,224,9) \mathrm{JB}$

8 PRINT $317, \operatorname{RNA}(1,1), \operatorname{CURS}(1,1), \operatorname{CUMS}(1,1), \operatorname{ACINS}(K, 1,1), \operatorname{CIRS}(1,1)$. RCS (K, 1, 1) , RTCURS (L, K, 1, 1)

9 PRINT $317, \operatorname{RNA}(2,1), \operatorname{CURS}(2,1), \operatorname{CUMS}(2,1), \operatorname{ACINS}(K, 2,1), \operatorname{CIRS}(2,1)$. RCS (K, 2,1$)$, RTCURS (L, K, 2, 1)

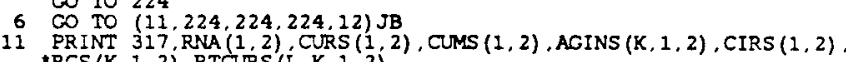
RCS $(K, 1,2)$ RTCURS (L, K, 1, 2)

12 PRINT 317, RNA $(2,2), \operatorname{CURS}(2,2), \operatorname{CUMS}(2,2), \operatorname{AGINS}(K, 2,2), \operatorname{CIRS}(2,2)$ -RCS (K, 2, 2), RTCURS (L, K, 2, 2)

15 PRINT 310.RCH (I 4, 14), DIS (L K, I 4 14), CUR (I 4, 14) CUM (I4, 14)

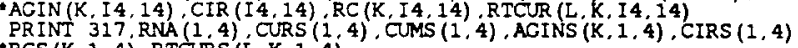
RCS $(K, 1,4)$, RTCURS (L. K, 1, 4)

16 PRINT 310,RCH (I 4, I4), DIS (L, K, I 4, I4), CUR (14, 14), CUM (I4 , 14), AGIN (K, I 4, 14), CIR (I 4, 14), RC (K, I 4, 14), RTCUR (L,K, I4, 14) PRINT 317, RNA $(2,4)$, CURS $(2,4)$ TO 228

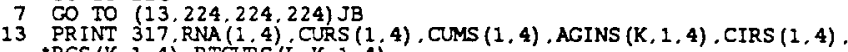
13 PRINT 317, RNA $(1,4)$, CURS $(1,4)$

224 CONTINUE

240 CONTINUE

250

CONTINUE $290 \mathrm{~L}=1, \mathrm{NL}$

$\mathrm{T}=0$.

DO $280 \mathrm{~K}=1$, NT

$T=T+T F A C(K)$
$D O$ 270 IB $=1$, NONNS

NB 270 IEC (IB)

DO $270 \quad \mathrm{JB}=1, \mathrm{NB}$

$R T=T T(L, M) * R D E(L, J B, I B)$

IF (RTT.LT.O. OR.T.GT.RTT) CO TO 270

TRT $T=T+R T$

IE (TRT.LT O.) CO TO 279

IRT=TRT-TFAC (KT)

$278 \mathrm{KRT}=\mathrm{KRT}+1$

279 CONTINU

SUR (L, KRT, JB, IB) =SUR (L, KRT, JB I B

*+RTCUR (L. KRT, JB, IB) *DEF (K) /DEF (KRT) *TEAC (K)

270 CONTINUE

DO $280 \mathrm{MI}=1$, NNECS

$M N=N E C S(M I)$

(L, MJ ,MI)

IE (RTTS.LT O .OR. I.GT.RTTS) CO TO 280

TRTS $=T+R T S$

DO $288 \mathrm{KT}=1$, NT

IF (TRTS.LT.O) CO TO 28

TRTS=IRTS - IEA

288 $\mathrm{CR}$ IS=KR IS 1

SURS (L. KRTS, MJ MI) =SURS (L, KRTS, MJ, MI) 280 CONTINUE

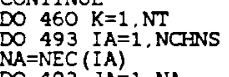

$\mathrm{NA}=\mathrm{NEC}$ (IA) 
$493 \operatorname{SUR}(4, K, J A, I A)=S U R(1, K, J A, I A)+\operatorname{SUR}(2, K, J A, I A)+\operatorname{SUR}(3, K, J A, I A)$

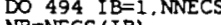

$D O 494 \mathrm{JB}=1$

$494 \operatorname{SURS}(4, K, J B, I B)=\operatorname{SURS}(1, K, J B, I B)+\operatorname{SURS}(2, K, J B, I B)+\operatorname{SURS}(3, K, J B, I B)$

460 CONTINÚE

DO $296 \quad I=1, N L$

DA 291

$\mathrm{NO} 291 \mathrm{JA}=1$, NA

$S T O T=0$.

STOTC $=0$.
DO $291 \mathrm{~K}=1, \mathrm{NT}$

STOT=STOT+SUR (L, K, JA, IA)

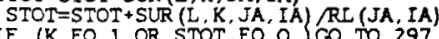

IE

- DEF (K-1) DEF (K)+SUR (L, K, JA, IA)

C 297 CONTINUE IA)

SLR $(L, K, J A, I A)=S T O T$

291 (

D 292 IB $=1$, NNECS

$\mathrm{NB}=\mathrm{NECS}(\mathrm{IB})$
$\mathrm{DO} 292 \mathrm{JB}=1, \mathrm{NB}$

STOTS $=0$.

STOTCS $=0$.

DO $292 \mathrm{~K}=1$, NT

STOTS $=$ STOTS +SURS (L, K, JB, IB) $/ R L S$ (JB, IB)

STOTS =STOTS+SURS (L.K.JB, IB)/RLS (JB,
IF (K.EQ.1.OR. STOTS.EQ.O.) CO TO 298

STOTCS $=$ STOTCS*RTCURS (L, K, JB, IB) RTCURS (L , K - I, JB , IB)

C "RLS (JB, IB)

RLS (JB, IB) $(K)+S U R S$ (L, $K, J B, I B)$

298 CONTINUE

SURS $(L, K, J B, I B)=S T O T S$
SUCS $\{L, K, J B, I B)=S T O T C S$

292

DO $295 \mathrm{~K}=1, \mathrm{NT}$

SAETOT $=0$.

$S A=T=0$

DO $293 \quad I A=1$. NCHNS

NA=NEC (IA)

DO 293 JA=1, NA

SAECID $=$ SAECID+SUC $(L, K, J A, I A)$

SAETOT=SAETOT+SUR (L,K,JA, IA

293 SAERAT=SAERAT+SUR (L, K, JA, IA) /RL (JA, IA)

C SAECIDESAECID+SUC $\{[, K, J A, I A)=$ SAE $(J A, I A)$

293 SAERAT =SAERAT+SUR

DO 294 IB $=1$, NNECS

DO $294 \mathrm{JB}=1$ (

DAE

SAETOT $=S A F T O T+S U R S$ ( $, K, J B, I B)$

294 SAFRAT=SAFRAT+SURS $(\mathrm{L}, \mathrm{K}, J B, I B) / R L S(J B, I B)$

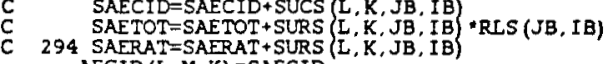

AECID $(L, M, K)=$ SAECID

AERAT $\{L, M, K\}=$ SAERAT

295

CONTINUT

DO $360 \quad K=1, N T$
DO 393 IA $=1$, NCHNS

NA $=$ NEC (IA)

$D O 393 \mathrm{JA}=1$ NA

$393 \operatorname{SUC}\{4, K, J A, I A)=S U R(2, K, J A, I A)+S U R(2, K, J A, I A)+S U R(3, K, J A, I A)$ $D O 394$ IB $=1$. NNECS

$\mathrm{NB}=\mathrm{NECS}(\mathrm{IB})$

$394 \operatorname{SURS}\{4, K, J B, I B)=\operatorname{SURS}(1, K, J B, I B)+\operatorname{SURS}(2, K, J B, I B)+\operatorname{SURS}(3, K, J B, I B)$

CIRAT $(4, M, K)=$ CIRAT $(1, M, K)+C I R A T(2, M, K)+C I R A T(3, M, K)$

AETOT $M K=A E T O T$ T $M K$ K +AETOT $M, K$ +AFTOT $3, M$

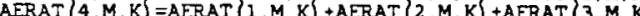

360 $A E C I D(4, M, K)=A E C I D(1, M, K)+A E C I D(2, M, K)+A E C I D(3, M, K)$

DO $366 \mathrm{~L}=1, \mathrm{NL}$

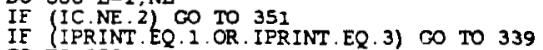

339 PRINT 103. I

PRINT 322 .

PRINT $323, Y R(K), \operatorname{CITOT}(L, M, K), \operatorname{CIRAT}(L, M, K)$, AETOT $(L, M, K)$,
"AERAT $(L, M, K), S U R(L, K, 1, i), S U R(L, K, 1,2)$.
"SUR $(L, K, 1,3), \operatorname{SUR}(L, K, 1,8), \operatorname{SUR}(L, K, 1,9), \operatorname{SUR}(L, K, 1,10)$

330 CONTINUE

DO $331 \quad K=1, N T$

PRINT $323, Y R(K), S U R(L, K, 1,11), \operatorname{SUR}(L, K, 1,12), \operatorname{SUR}(L, K, 1,13)$

*SUR (L, K, I, 4), SUR (L, K, 2,4$),$ SUR (L, K, 3, 4) , SUR (L, K, 4, 4).

- SUR (L, K, 1,5 ), SURS $(i, K, i, 1)$, SUR $(L, K, 2,5)$

331 CONTINUE

PRINT 327

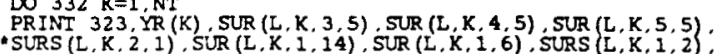

•SURS (L,K, 2,1$)$, SUR $(L, K, 1,14)$, SUR $(L, K, 1,6), \operatorname{SURS}(L, K, 1,2)$

332 CONTINUE

PRINT 328

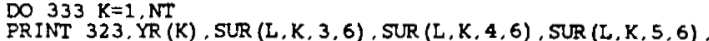

- SURS $(L, K, 2,4)$, SUR $(L, K, 1,7)$, SURS $(L, K, 1,3)$, SUR $(L, K, 2,7)$.

-SUR $(L, K, 3,7)$, SUR (L, K, 4, 7), AECID (L, M, K)

33 CONTINEE

PRINT 329

DO $334 \mathrm{~K}=1, \mathrm{NT}$

PRINT 323, YR (K) , SURS $(L, K, 1,4)$, SUR (L, K, 4, 14), SUR (L, $K, 5,14)$,

334 CONTINUE

IE (IPRINT.EQ.2.OR. IPRINT.EQ.3) CO TO 439

439 PRINT 322

DO $430 \mathrm{~K}=1$, NT $, C I T O T(L, M, K), C I R A T(L, M, K)$, AETOT $(L, M, K)$

*ARRAT (L, M, K), SUC $(L, K, 2,1)$, SUC $(L, K, 1,2) ; \operatorname{SUC}(L, K, 1,10)$

430 CONTINUTE

PRINT 326

DO $431 K=1, N T$ T

SUC $(L, K, 1,4), \operatorname{SUC}(L, K, 2,4), \operatorname{SUC}(L, K, 3,4), \operatorname{SUC}(L, K, 4,4)$

431 CONTINUE

DO $432 \mathrm{~K}=1$ MT

PRINT $323, Y R(K), \operatorname{SUC}(L, K, 3,5)$, SUC $(L, K, 4,5)$, SUC $(L, K, 5,5)$

*SUCS $(L, K, 2,1)$, SUC $(L, K, 1,14), \operatorname{SUC}(L, K, 1,6)$

432 CONTINUE

PRINT 328

DO $433 \mathrm{~K}=1, \mathrm{NT}$

(K) SUC (L, X, 3, 6), SUC $(L, K, 4,6), \operatorname{SUC}(L, K, 5,6)$

+SUCS $(L, K, 2,4)$, SUC $(L, K, 1,7\}$, SUCS $(L, K, 1,3)$.SUC $(L, K, 2,7)$.

+ SUC (L, K, 3,3$)$

PRINT 329

DO $434 \mathrm{~K}=1 \mathrm{NT}$

PRINT $323, \mathrm{YR}(\mathrm{K}), \operatorname{SUCS}(L, K, 1,4), \operatorname{SUC}(\mathrm{L}, K, 4,14), \operatorname{SUC}(\mathrm{L}, \mathrm{K}, 5,14)$

434 COCS (L,K, 2,

434 CONTINUE

366 CONTINUE

IF (ITOTAL. NE.1) 10 TO 500

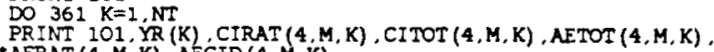

361 CONTINUE

100 FORMA'S(1H1, 3X, "RECHARGE M/MR", 3X," FLUX M/YR ",

"3X, "VELOCI TY M/YR",2X "* $25 \%$ ELUX"

101 FORMAT $5 \mathrm{XX}, 7$ (1PE10, $2,5 \mathrm{X}))_{\text {. }}$ (IPIRAT", 10X, "CITOT", 10X, "AETOT"

2 EORMAT ( / /8X, "TIME", 10X,

"

300 FOPMAT $10 X$ "INDECAYED")

301 FORMAT $5 X, A 8, " C M="$ 1PE10, 2, 10X, "C1=", IPE1O . 2)

302 FORMAT 8OX, "TIME =", 1 PE10.2)

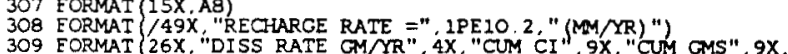

309 EORMAT 26X "DISS RATE GM/YR" 4X "CUM CI "9X, "CUM GM" .9X

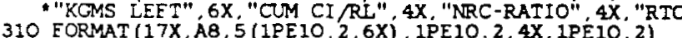

310 EORMAT $17 X$, AB, 5 (1PE10.2,6X), 1PE1O 2, 4X.1PE10.2)

312 FORMAT 3X "CHATN 2 - TEPTNTIM

313 FORMAT 3X "CAAIN 3 - URANIM SERIES")

314 FORMAT 3X" "CHAIN 4 - ACTINIUM SERIES")

315 FORMAT 3X. "ACTIVATION PRODUCTS")

316 FORMAT 3X, I $3,3 X, I 3,3 X, 5$ (1PE1O . 2, 5X) , 10X, "TIME =", 1PE 10.2 )

317 FORMAT 17X, AB, 16X, 4 (1PE1O 2, 6X), IPEIO. 2, 4X, 1PE1O'. 2)

318 FORMAT 10X, 3(1PE10.2, 10X)) 319 FORMAT IHI, $7 X$. "TIME", 10X. "RECHARGE", 10X, "TOTAL CURIES")

320 FORMAT 
322 FORMAT (//2X, "TIME", 2X, "TOTAL CURIES", 2X, "DIS EPA RATIO",

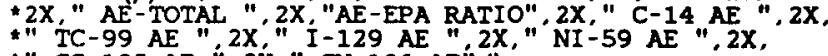

*" CS-135 AE ". 2X," SN-126 AE"

323 EORMAT (11 (1PE1O.2 2X)

325 FORMAT 99X. "RECHARGE RATE $="$. 1PE10.2)

326 FORMAT //,5X, "TIME", 4X

" ZR -93 Á" 2X" "SR-9O AE " 2X." CS-137 AE"

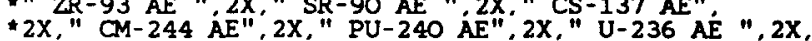

*"TH-232 AE", 2X," CM-245 AE", 2X," PU-241 AE", 2X

" AM-241 AE"

327 FORMAT (/,5X, "TIME", 4X," NP-237 AE", 2X

" U-233 AE" 2X," TH-229 AE". 2X." RA-225 AE"

*2X " CM-246 $\dot{A} E^{\prime \prime}, 2 X, " A M-242$ AE", 2X,"CM-242 AE", $2 X$

" "PU-242 AE" 2X," PU-238 AE", 2X,"U-238 AE " $/$ )

328 FORMAT / $/ 5 X, " T I M E ", 4 X, " U-234$ AE", 2X," TH-230 AE", 2X,

" RA-226 AE", 2X," PB-210 AE", 2X," AM-243 AE"

"2X." NP-239 AE", 2X," PU-239 AE", 2X,"U-235 AE ", 2X

"PA-231 AF" 2X "AFCID"

329 FORMAT (/, 5X, "TIME", 4X, "U-234* AE", 2X, "TH-230* AE", 2X,

9999 STOP

SUBROUTINE BAT (NCHNS, AL, T, NEC, CONI , TM21, TM31, TM41, TM32, TM42,

*TM43, TM51, TM52, TM53, TM54, CONN

DIMENSION AL $(5,14)$, TM21 (14) . TM31 (14) TM41 (14) TM32 (14)

*TM43 (14), TM42 (14), EXT (5,14), NEC (14), CONI (5,14), CONN (5, 14)

TM51 (14), TM52 (14), TM53 (14), TM54 (14)

DO 2 I=1, NCHNS

$\mathrm{N}=\mathrm{NEC}(\mathrm{I})$

DO $2 \quad J=1, N$

$Z=-A L(j, I) * T$

$\operatorname{IF}(Z . G T,-1 . E 1000)$ GO TO 5

$\operatorname{EXT}(J, I)=0$.

GO TO 6

$5 \quad \operatorname{EXT}(J, I)=\operatorname{EXP}(Z)$

6 CONTINUE

DO 3 I I N NCHNS

$\mathrm{C} 1=\operatorname{CONI}(\mathrm{i}, \mathrm{I})$

$\mathrm{C} 2=\mathrm{CONI}, 2, \mathrm{I}$

C3 $=$ CONI 3 . I

$\mathrm{C} 4=\mathrm{CONI}, 4, \mathrm{I}$

C5 $=$ CONI $\{5, I\}$

$\mathrm{N}=\mathrm{NEC}(\mathrm{I})$

$\operatorname{CONN}(1, I)=C 1 * \operatorname{EXT}(1, I)$

IF (N.EQ.1) CO TO 4

$X=A L(i, I) * T M 21(I) * C 1$
$Y=-X+C i$

$\operatorname{CONN}(2, I)=X * \operatorname{EXT}(1, I)+Y \star \operatorname{EXT}(2, I)$
$X=A L(1, I) * A L(2, I) * C 1$

$X 1=X^{*} \operatorname{TM} 21$ (I) *TM31 (I) ${ }^{*} \operatorname{EXT}(1, I)$

$Y=-X *$ TM21 $(I) *$ TM32 $(I)+A L(2, I) * C 2 * \operatorname{TM} 32$ (I)

$Y 1=Y * \operatorname{EXT}(2, I$

$Z=X * \operatorname{TM} 31$ I I) *TM32(I) -AL (2,I)*C2*TM32(I) +C

$Z 1=Z * \operatorname{EXT}(3,1)$

$\operatorname{CONN}(3, I)=X 1+Y 1+Z 1$

IF (N.EQ. 3) CO TO 4

$X=A L(1, I) * A L(2, I) * A L(3, I) * C 1$

$Y=A L(2, I) * A L(3, I) * C 2$

$X 1=X * \operatorname{TM} 21$ (I) *TM31 (I) *TM41 (I) *EXT (1, I)

$Y 1=-X * \operatorname{TM} 21(\mathrm{I})$ *TM32 (I) *TM42 (I)

$Y 1=Y 1+Y * T M 32(I) * T M 42(I)$

$Y 1=Y 1 * \operatorname{EXT}(2, I)$

$\mathrm{Z1}=\mathrm{X} * \mathrm{TM} 31(\mathrm{I}) * \mathrm{TM} 32$ (I) *TM43 (I)

$Z 1=Z 1-Y * T M 32$ (I) *TM43(I)

$Z 1=Z 1+C 3 * A L(3, I) * \operatorname{TM} 43(1)$

$\mathrm{Z1}=\mathrm{Z1} * \operatorname{EXT}(3, \mathrm{I})$

$W 1=-X * T M 41(I) * T M 42(I) * T M 43(I)$

$W 1=W 1+Y * T M 42$ (I) *TM43 (I)

$W 1=W 1-A L(3, I)+C 3 * I M 43(I)+C 4$

$W 1=W 1 * \operatorname{EXT}(4,1)$

$\operatorname{CONN}(4, I)=X 1+Y 1+Z 1+W 1$

IF (N.EQ.4) GO TO 4

$A 1=A L(1$ I I *AL $(2, I) * A L(3, I) * A L(4, I) * C 1$

$A 2=A L\} 2, I\{* A L\} 3, I) * A L, 4, I) * C 2$

$A 3=A L(3, I) * A L(4, I) * C 3$

$U=A 1 * \operatorname{TM} 21$ (I) *TM31 (I)*TM41 (I) *TM51 (I)

$\mathrm{U}=\mathrm{U} * \operatorname{EXT}(1, \mathrm{I})$

$\mathrm{V}=-\mathrm{A} 1$ *TM21 (I) *TM32 (I) *TM42 (I) *TM52 (I)

$\mathrm{V}=\mathrm{V}+\mathrm{A} .2 * \operatorname{TM} 32$ (I) *TM42 (I) *TM52 (I)

$V=V \star E X T(2, I)$

$W=A I$ *TM31 (I)*TM32 (I) *TM43 (I)*TI53(I)

$W=W-A 2 * T M 32(I) * T M 43(I) *$ IMS $3(I)$

$W=W+A 3 * \operatorname{TM} 43$ (I) *IM53 (I)

$W=W^{*} E X T(3, I)$

$X=-A 1$ *TM41 (I) *TM42 (I) *TM43 (I) "TM54 (I)

$X=X+A 2 * T M 42$ (I) *TM43 (I) *TM54 (I)

$X=X-A 3 * T M 43$ I $\{*$ TM5 $\}$ I

$\mathrm{X}=\mathrm{X}+\mathrm{AL}(4, \mathrm{I}) * \mathrm{C} 4 * \mathrm{TM} 54$ (I)

$X=X \star \operatorname{EXT}(4,1)$

$Y=A 1$ *TM51 (I) *TM52 (I) *TM53 (I) *TM54 (I)

$Y=Y-A 2 * T M 52$ (I)*TMS3 (I)*TMS4 (I)

$Y=Y+A 3 * T M 53$ (I) * TM54 (I)

$Y=Y-T M 54(I) * A L(4, I) * C 4$

$\begin{aligned} Y= & Y Y+C 5 \\ \operatorname{CONN}(5, I & =\operatorname{EXT}(5, I) \\ =U+V+W+X+Y & \end{aligned}$

CONTINUE

CONTINUE

ENT 


\section{APPENDIX B}

COMPUTER SOURCE LISTINGS OF UCB-NE-10.3

This section contains a detailed computer program and the input data used to calculate the analytical solutions.

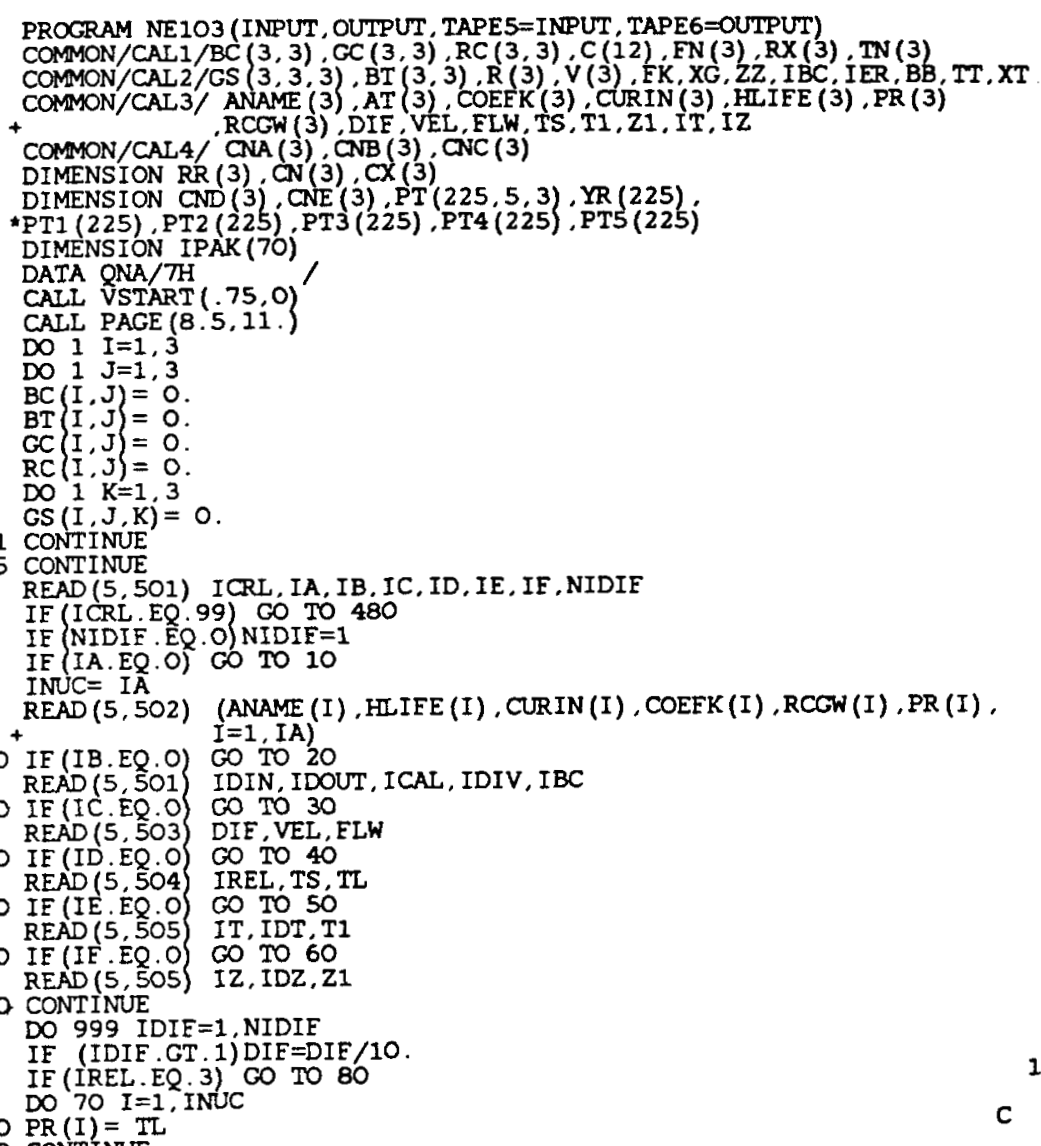

IE (INUC. EQ.2) CO TO 120

$\mathrm{R} 23=\mathrm{RR}(2)-\mathrm{RR}(3)$

$\mathrm{R} 31=\mathrm{RR}\} 3-\mathrm{RR}(1)$

$R R R=A T(1) * R(1) * R(2) * P R(1) / P R(3)$

$B C\left\{\begin{array}{l}3,1 \\ B, 2\end{array}=-R R R /(R 12 * R 31)=-R R R /(R 12 * R 23)-A T(2) * R(2) / R 23 * P R(2) / P R(3)\right.$

BC $\{3,3\}=-R R R /(R 23 * R 31)+A T(2) * R(2) / R 23 * P R(2) / P R(3)+A^{*}$

$\mathrm{RC}\{2,1\}=-\mathrm{RC}(1,2)$

$R C\{3,1\}=R(3) \sim N(3)-R(1) N(1)$

$\mathrm{RC}\{1,3=-\mathrm{RC}(3,1)$

$\mathrm{RC}\{3,2\}=R(3) N(3)-R(2) N(2)$

$\mathrm{RC}\{2,3\}=-\mathrm{RC}(3,2)$

$\mathrm{RC}\{2,1\}=-\mathrm{GC}\{1,2\}$

GC $\{3,1\}=1.0 / V(3)-1.0 / V(1)$

$\operatorname{CC}(1,3)=-\operatorname{GC}(3,1$

$G C\left\{\begin{array}{l}3,2 \\ 2\end{array}=1.0 N(3)-1.0 / N(2)\right.$

$G C(2,3)=-G C(3,2)$

$\mathrm{BT}\{1,3\}=\mathrm{RC}\{(1,3) / \mathrm{GC}(1,3)$

$\mathrm{BT}\{3,3\}=\mathrm{RR}(3)$

$\operatorname{GS}\{1,3,1\}=\operatorname{GMF}(1,3,1)$

$G S\{2,3,2\}=G M F\{2,3,2\}$

GS $\{1,1,3=$ GMF $1,1,3$

GS $\{1,3,3\}=G M E(1,3,3$

GS $2,2,3)=$ GME $2,2,3$

CS $(2,3,3)=$ CMF $(2,3,3)$

$\operatorname{GS}(3,3,3)=\operatorname{GME}(3,3,3)$

$\mathrm{RV} 2=\mathrm{R}(2) \sim \mathrm{N}(2)$

$\mathrm{C}(2)=\mathrm{RV} 2 /(\mathrm{RC}(2,3)-\mathrm{RR}(2) * \mathrm{CC}(2,3))$

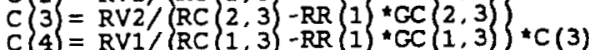

$\mathrm{CA}=\mathrm{RV} 3 /\left(\mathrm{GC}(1,3) *_{\mathrm{RC}}(2,3)-\mathrm{GC}(2,3){ }_{\mathrm{RCC}}(1,3)\right.$

$\left.\mathrm{CB}=\mathrm{RV} 3 / \mathrm{CC}\{3,2\} * \mathrm{RC}\{1,2\}-\mathrm{GC}\left\{\begin{array}{l}1,2 \\ \mathrm{C} C \mathrm{RC}\end{array} 3,2\right\}\right\}$

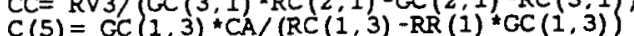

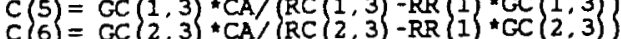

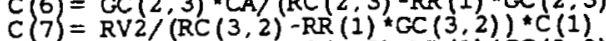

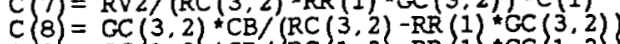

政

C $10=R V 3 /(R C(3,1)-R R(1) * C C(3,1))(R C(2,1)-R R(1) * C C(2$ C $\{11=\mathrm{GC}(3,1) * \mathrm{CC} /(\mathrm{RC}\{3,1)-\mathrm{RR}(1) * \mathrm{GC}(3,1)\}$

120 CONTINUE

CONTINUE

C

FOR $99 . /$ ELOAT (IDZ)
$\mathrm{DD} 420$ M=1.IT

7O PR(IT)

DO $90 \mathrm{I}=1.3$

$\operatorname{CND}(I)=0$.

CNE (I) $=0$

$90 \underset{K T=0}{C O N T I N}$

ATOMIC CONSTANTS

$A K=1.16683 \mathrm{E} 18$

FK $=$ DIF $/$ VEL

VMIN $=1 . E 1 \infty$

VMAX $=0$.

DO $100 \mathrm{~K}=1$, INUC

$A=A L O G(2.) / H L I E E(K)$

$A=\mathrm{PR}(\mathrm{K})$

$B C(2,1)=-A T(1) * R(1) / R 12 * P R(1) / P R(2)$

$\mathrm{BC}\{2,1)=-\mathrm{AT}(2)-\mathrm{BC}(2,1)$

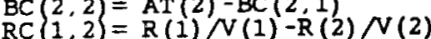

$R C\{1,2\}=R(1) N(1)-R(O N(2)$

$\mathrm{GC}\{1,2\}=1 . \mathrm{RC}(1,2) / \mathrm{GC}(1,2)$

${ }_{\mathrm{BT}}^{\mathrm{BT}}\left\{\begin{array}{l}1,2 \\ 2,2\}=\mathrm{RR}(2)\end{array}\right.$

GS $(1,2,1)=G M E(1,2,1)$

GS $\{1,1,2)=$ GMF $\{1,1,2$

GS $\left\{\begin{array}{l}2,2,2 \\ \text { GS }\end{array}\right\}=$ GMF $\left\{\begin{array}{l}2,2,2 \\ 1,2,2\end{array}\right\}$

$\mathrm{RV} 1=\mathrm{R}(1) \sim(1)$

$C(1)=R V 1 /(R C(1,2)-R R(1) * G C(1,2))$
$R(K)=A$

$R X(K)=A$

IN $(K)=B$

$V(K)=$ VEL $/ \operatorname{COEFK}(K)$

$A I(K)=\operatorname{CURIN~}(K)$

IF IDIN.EO. 1) AT (K) = AT (K) *AK/A

IE VMIN.GT V V(K) VMIN $=V$ V $(K$

IF $V M A X . L T \cdot V(K), V M A X=V(K)$

$R R(K)=A$

100

IF (IREL.NE. 1) RR $(K)=A+1 \cdot / B$

CONTINUE

$\mathrm{BC}(1,1)=\mathrm{AT}(1)$

$E 1=\operatorname{EXP}(-R(1) * T S)$

$W A=B C(1,1) * E 1$

IF IDIN.EQ.1) $C N(1)=C N(1) * R(1) / A K$

IF (INUC.NE.1) CO TO 102

ANAME $(2)=$ QNA

ANAME $(3)=$ QNA

CO TO 110

102 CONTINUT

$R 12=R(1)-R(2)$

$B C(2.1)=-A T(1) * R(1) / R 12$ 


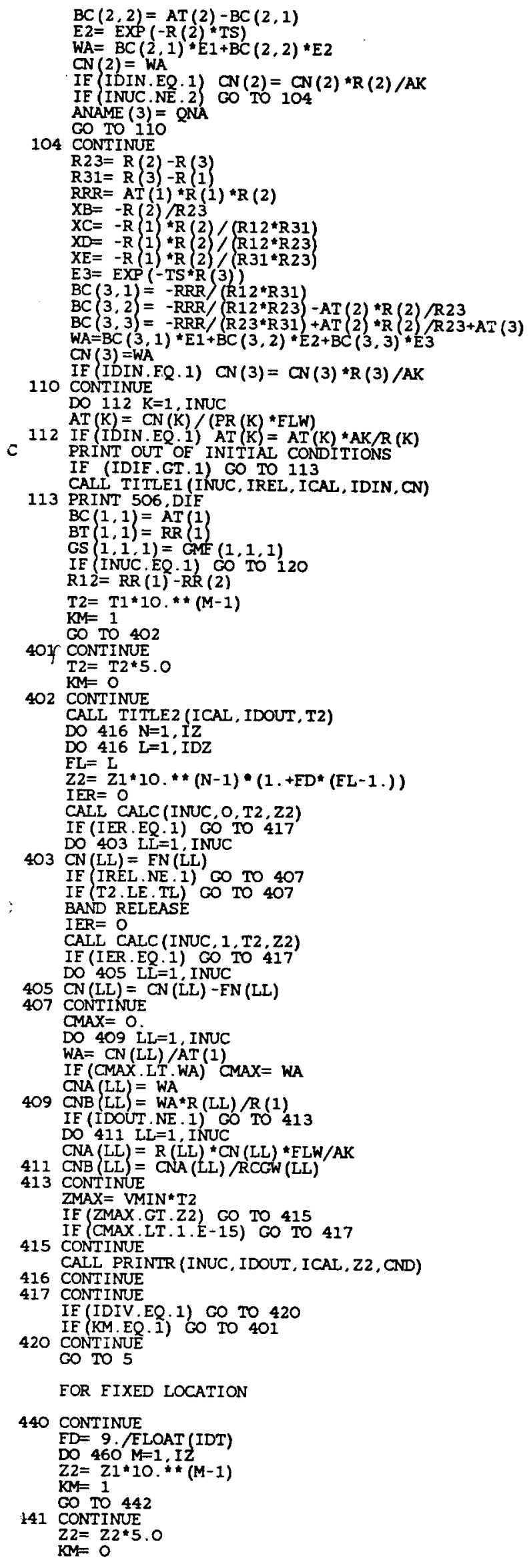

442 CONTINUE

CALL TI TLE2 (ICAL, IDOUT, Z2)

$\mathrm{TX}=0$

$Q A=0$.

$\mathrm{QB} 1=0$.

$\mathrm{QB}^{\mathrm{B} 2}=0$.

$\mathrm{OC}^{2}=0$.

$\mathrm{OC}_{2}=0$.

OC $3=0$.

DO $454 \mathrm{~N}=1$, I

DO $454 \quad \mathrm{~N}=1$, IT

EL= $=$ L

c

$\mathrm{T} 2=\mathrm{T} 1 * 10 \cdot \cdots(\mathrm{N}-1) *(1 .+\mathrm{FD} *(\mathrm{FL}-1)$.

C IER $=0$

CALL CALC (INUC, O T2,Z2)

IF (IER. EO.1) GO TO 456

443 DO 443 LL=1, INUC

$443 \mathrm{CN}(L L)=E N(L L)$

IF (IREL.NE. 1) CO TO 446

$\stackrel{\mathrm{C}}{\mathrm{C}}$

IF (T2.LE.TL) CO TO 446

C BAND RELEASE

$\mathrm{IER}=0$

CALL CALC (INUC, 1,T2,Z2)

IE (IER. EQ.1) GO TO 456

DO 444 LL $=1$. INUC

$444 \mathrm{CN}(L L)=C N(L L)-E N(L L)$

446 CONTINUE

$D E T=T 2-T X$

IF (IDOUT.EQ.O) 60 TO 1000

$E 1=\operatorname{EXP}(-R\}$ i $* D E T)$

$Q A=Q A * E 1+(1 . O-E 1) * C N(1) / R(1)$

$\mathrm{CX}(1)=\mathrm{QA}$

IF (INUC.EQ.1) CO TO 1000

$E 2=\operatorname{EXP}(-\mathrm{R}(2) * D E T)$

$\mathrm{QB} 1=\mathrm{QB1} * \mathrm{E} 1+\left(1.0-\mathrm{E}_{1}\right) * \mathrm{CN}(1) * \mathrm{XA} / \mathrm{R}(1)$

$\mathrm{QB} 2=\mathrm{QB} 2 * \mathrm{E} 2+\{1 \cdot 0-\mathrm{E} 2\} *(\mathrm{CN}(2)-\mathrm{CN}(1) * \mathrm{XA}) / \mathrm{R}(2)$

$\mathrm{CX}(2)=\mathrm{QB} 1+\mathrm{QB} 2$

IE (INUC.EQ.2) GO TO 1000

$E 3=\operatorname{EXP}(-\mathrm{R}(3) * \mathrm{DET})$

$\mathrm{QCI}=\mathrm{QC1} * \mathrm{E} 1+(1.0-\mathrm{E} 1) * \mathrm{CN}(1) * \mathrm{XC} / \mathrm{R}(1)$

$\left.\mathrm{QC2}=\mathrm{QC2} 2^{\star} \mathrm{E} 2+(1 . \mathrm{O}-\mathrm{E} 2)^{*} \mathrm{XB} * \mathrm{CN}(2)+\mathrm{XD}^{*} \mathrm{CN}(1)\right) / \mathrm{R}(2)$

$Q C 3=Q C 3 * E 3+(1 \cdot 0-E 3) *(C N(3)-X B * C N(2)+X E * C N(1)) / R(3)$

$1000 \mathrm{CO}(3)=Q \mathrm{C} 1+\mathrm{QC} 2+\mathrm{QC} 3$

CMAX $=0.0$

DO 447 LL $=1$, INUC

WA $=C N(L L) / A T(1)$

IF (CMAX.LT.WA) CMAX = WA

CNA (LL) = WA

CNA $(L L)=$ WA

CNB (LL) $=$ WA*R (LL) $/ R(1)$
$\operatorname{IE}(I D O U T$. NE.1) GO TO 450

DO $448 \mathrm{LL}=1$, INUC

$\mathrm{CNA}(L L)=R(L I) * C N(L L) * F L W / A K$

CND $(L L)=C N D(L L)+D E T^{*}(C N E(L L)+C N A(L L)) / 2$

$W A=R(L L) * C X(L L){ }^{*} E L W / A K$

CNC (LL) $=$ WA $/$ RCGW $(L L)$

448 CNB $($ LI $)=$ CNA (LL) /RCGW (LL)

DO $449 \mathrm{LL}=1$, INUC

449 CNE (LI) =CNA (LL)

450 CONTINU

$\mathrm{TX}=\mathrm{T} 2$

TMAX $=\mathrm{Z2} / \mathrm{MMIN}+\mathrm{TL}$

IF (TMAX.GT.T2) GO TO 452

IF CMAX.LT.1.E-15) CO TO 456

452 CONTINUE

TS2 $=$ T2 + TS

CALL PRINIR (INUC, IDOUT, ICAL, TS2, CND)

$\mathrm{KT}=\mathrm{KT}+1$

$\mathrm{YR}(\mathrm{KT})=\mathrm{TS} 2$

DO 600 JJ $=1$, INUC

600 PT (KT, IDIF, JJ) $=$ CND (JJ)

454 CONTINUE

456 CONTINUE

IF (IDIV.EQ.1) CO TO 460

460 CONTINUE

999 CONTINUE

$\mathrm{IV}=2$
$\mathrm{IC}=2$

$\mathrm{IC}=2$

NT $=$ KT

PTMIN=1.E-7

DO $910 \mathrm{~L}=1$, INUC

CALI RESET ("ALL")

CALL AREA2D (7.5.10

CALLL AREADIN ("CUMMULATIVE CURIES RELEASED FOR

CALL HEADIN (" 300 YEARS OLD INVENTORIES\$", $100,1,3)$

CALL HEADIN '" (FLUX THROUGH $2.5 \%$ OE MINED' AREA) \$", $100, .75,3$ )

CALL XNAME ("TIME AFTER CLOSURE (YR) \$", 100)

CALL YNAME ("CUMMULATIVE CURIES RRELEASE (CI) $\$ ", 1 \infty)$

$\operatorname{PT} 1(K)=P T(K, 1, L)$ 


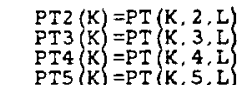

809 CONTINUE

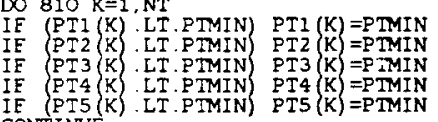

810

CALL NOCHEK

CALL GRACE $(0.0)$, 8, PTMIN 1,

IDUM=LINEST (IPAK, 70, 10)

CALL LEGLIN

CALL LECLIN

IF (NIDIE.EQ.1) CO TO 900

CALL DASH

CALL CURVE (YR,PT2,NT, O)

CALL RESET ("DASH") TO 900

CALL DOT

CALL CURVE (YR, PT3,NT, O)

CALL RESET ("DOT")
IF (NIDIF.EQ.3) Co To 900

CALL CHNDOT

CALL CURVE (YR.PT4,NT,O)

CALL RESET "CHNDOT" To 900

CALT

CALL CURVE (YR, PTS, NT, O)

900

CONTINUE

CALL LINESP (2.)

CALL LINES "D=10 \$", IPAK, 1

CALL LINES ( $D=10 . \$ "$ "I IPAK, 2)

CALL LINES " $D=1 . \$ "$ "IPAK, 3)

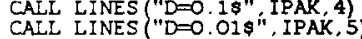

CALI LINES("D=0.01\$", IPAK, 5)

CALL ERAME

910 COLL ENDPL

CONTINUE

480 STOP

501 FORMAT (8I 2 )

502 FORMAT (A7, 5F 8 .O)

503 FORMAT (3FB.O)

504 FORMAT I 1 . 2F8.0)

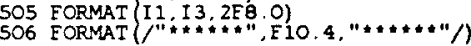

END

COMMON/CAL $1 / B C(3,3), G C(3,3), R C(3,3), C(12), \operatorname{EN}(3), R(3), \pi L(3)$ DIMENSION TM (3), B $(3,3)$

$10 \mathrm{TM}$ (I) $=1$.

IF (IK. EQ.O) GO TO 30

$20 \mathrm{TM}(\mathrm{I})=\operatorname{EXP}(-\mathrm{R}(\mathrm{I}) \star \mathrm{TL}(\mathrm{I}))$

30 CONTINUE

DO $40 \quad I=1$. INUC

$40 \mathrm{~B}(I, J)=B C(I, J) \cdot \operatorname{TM}(J)$

DO $50 \mathrm{I}=1$. INUC

$\operatorname{TM}(I)=T$

IE (IK.EQ.O) $C O$ TO 70

$60 \mathrm{TM}(\mathrm{I})=\mathrm{T}-\mathrm{IL}(\mathrm{I})$

CONTINUE

$T A=\operatorname{TM}(1)$
$X A=\operatorname{EEN}(1,1,1, T A, Z)$

EN (1)= $B(1,1) \div X A, Z$

$\mathrm{TB}=\mathrm{TM}(2)$

$\mathrm{XB}=\mathrm{EFN}(2,2,2, \mathrm{~TB}, \mathrm{Z})$

$X C=E F N(1,1,2, T B, Z)$

YA $=$ RC (1, 2) /CC (1, 2)
IF (YA.LT.O.) CO TO 200

$X D=E F N(1,2,2, T B, Z)$

$X E=E E N(1$
$X M=X E-X D$

200 CONTINUE

$X Y=\operatorname{EFC}(1,2,2, T B, Z)$

210 CONTINU

$\mathrm{EN}(2)=\mathrm{B}(2,2) * \mathrm{XB}+\mathrm{B}(2,1) * \mathrm{XC}+\mathrm{B}(1,1) * \mathrm{C}(1) *(\mathrm{XC}-\mathrm{XA}+\mathrm{XM})$

IE (INUC.EQ.2) CO TO 100

$\mathrm{TC}=\operatorname{TM}(3)$
$\mathrm{XF}=\operatorname{EFN}(3,3,3, \mathrm{TC}, \mathrm{Z})$

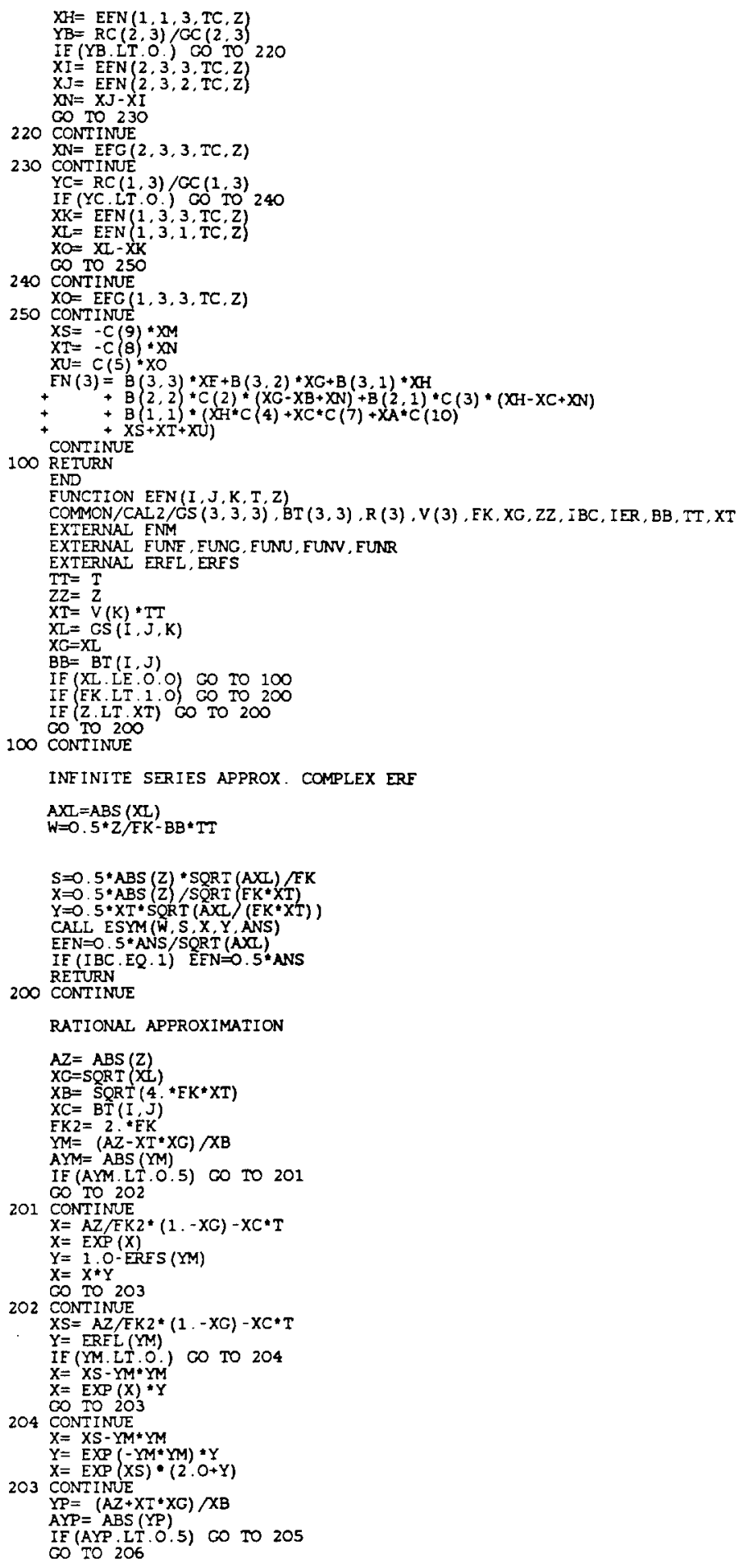




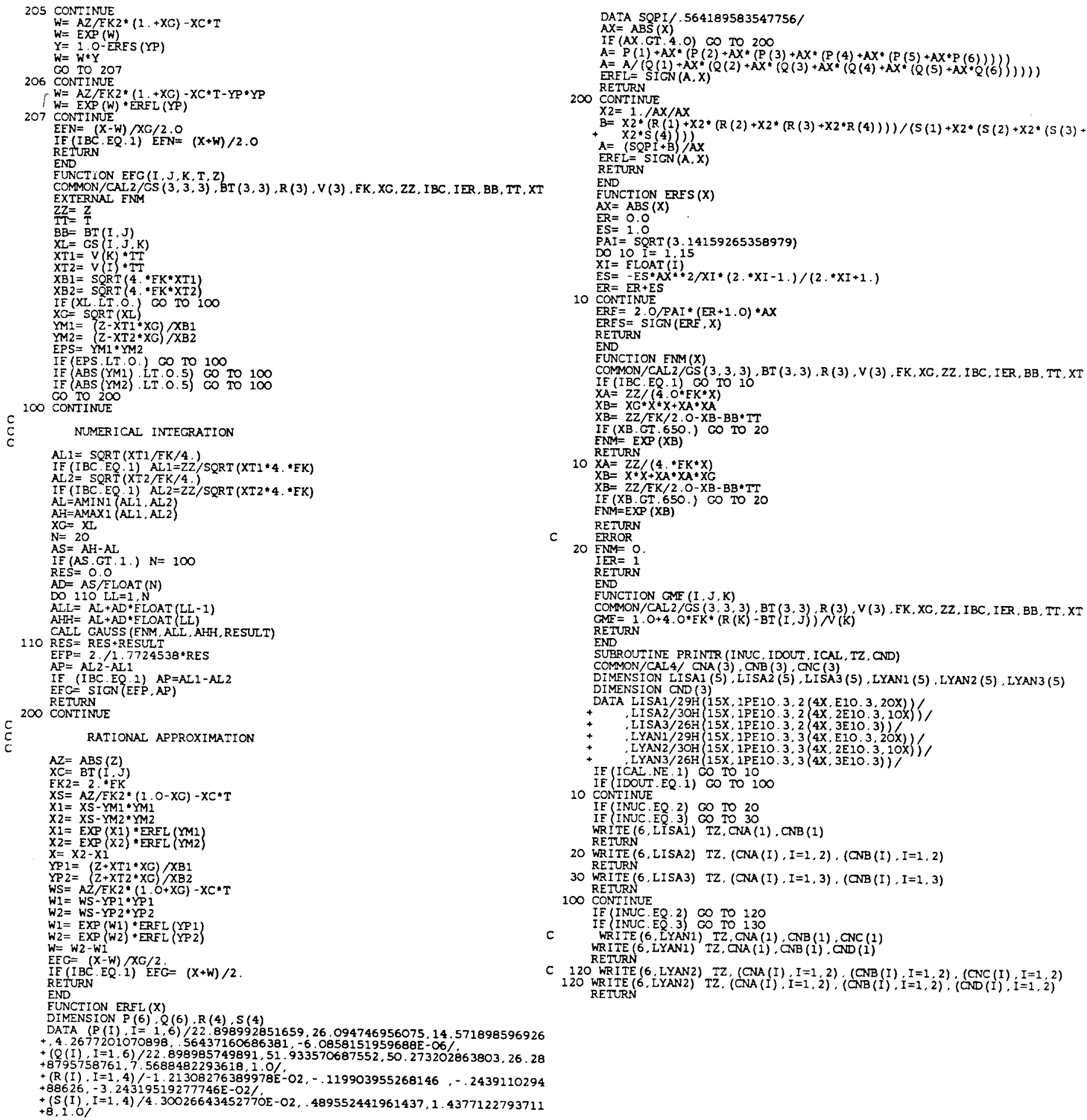

$\mathrm{AL} 1=\mathrm{SQRT}(\mathrm{XT1} / \mathrm{FK} / 4$.
$\mathrm{IF}(\mathrm{IBC}$. EQ. 1$)$ ALI=ZZ) $\mathrm{SQRT}(\mathrm{XT1} 14 . * \mathrm{FK})$

IF (IBC. EQ 1) ALL $2=Z Z / S Q R T$ (XT2*4. *FK)

$A L=A M I N 1$ (ALI 1 . AL 2 2

AH=AMAXI

$\mathrm{N}=20$

$A S=A H-A L$

IE (AS.GT.1.) $\mathrm{N}=100$

RES $=0.0$

$A D=A S / F L O A T(N)$

$A L L=A L+A D+F L O A T(L L-1)$

$A H H=A L+A D * F L O A T$ (LL)

CALL CAUSS (ENM, ALL, AHH, RESULT)

110 RES $=$ RES + RESULT

EEP $=2 . / 1.77245$

IF (IBC.ED 1) AP=AL1-AL2

EFC = SIGN(EEP, AP)

200 CONTINUE

C RATIONAL APPROXIMATION

$A Z=A B S(Z)$
$X C=B T(I, J)$

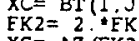

$X S=A Z / E K 2 *(1.0-X C)-X C * T$

$X_{1}=X^{2}-Y_{1} \cdot Y_{1} \cdot Y_{1}$

$\mathrm{X}_{2}=\mathrm{XS}^{\mathrm{X}} \mathrm{YM} 2 \cdot \mathrm{YM} 2$

$X_{1}=\operatorname{EXP}\left\{X_{1}\right): \operatorname{RRFL}(\mathrm{MM} 1)$
$X 2=E X P$

$X=x_{2}-X_{1}$

$\mathrm{YP} 1=(\mathrm{Z}+\mathrm{XT1} 1 \times \mathrm{XG}) / \mathrm{XB}$

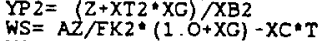

WI $=$ WS-YPI $Y Y Y^{\prime}$

$W_{1}=\operatorname{EXP}\left(W_{1}\right){ }^{* E R F L}(Y P 1)$

$w=W 2-w 1$

$E E C=(X-W) / X C / 2$

IF (IBC.EQ.1) EFG- $(X+W) / 2$

RETURN

END

DIMENSION $P(6), Q(6), R(4), S(4)$

DATA (P (I) $I=1,6) / 22.898992851659,26.094746956075,14.571898596926$

$+(Q(I), I=1,6) / 22.898985749891,51.933570687552,50.273202863803,26.28$

$+(\mathrm{R}(\mathrm{I}) \cdot I=1,4) /-1.21308276389978 \mathrm{E}-02,-.119903955268146,-2439110294$

$+(S(I), I=1,4) / 4.30026643452770 E-02, .489552441961437,1.4377122793711$
$+8,1.0 \%$ 

C 130 WRITE $(6, \operatorname{LYAN} 3) \operatorname{TZ},(\operatorname{CNA}(I), I=1,3),(\operatorname{CNB}(I), I=1,3),(\operatorname{CNC}(I), I=1,3)$
130 WRITE $(6, \operatorname{LYAN} 3) \operatorname{TZ},(\operatorname{CNA}(I), I=1,3),(\operatorname{CNB}(I), I=1,3),(\operatorname{CND}(I), I=1,3)$
$\operatorname{RETURN}$

SUBROUTINE TITLE1 (INUC, IREL, ICAL, IDIN, ONX) 3) COMMON/CAL 3/ ANAME (3), AT (3), COEFK (3), CURIN (3), HLIFE (3) .PR (3)

RCCW (3) DIF VEL FLW TS, T1,Z1, IT, IZ

DIMENSION A (3) B (2) D $(2)$ CNX (3) F (2)

DATA A (1),A $(2), A\{3\}, B(1\}, B(2), B(1), B(2) / 7 H R A N D$ RL, THEXP RL, THPREF + RL, THFIXED 2 , THF IXED T, TH (CIM3), TH (N/M3)

DATA E (1), E (2)/THSOURCE, THCONC. B/

$\infty$ FORMAT ( 1 H1. $/ 1 / / / 40 X,---$ MIGRATION OE 1 I1."-MEMBER GHAIN THRU A SORBING MEDIUM -

WRITE $(6.601)$ VEL, DIE, ELW 57X, $(M / Y) \quad(M 2 / Y)$ (M3/Y)* $(1 / 5 X, 1 \mathrm{PEB} .2,2(2 \mathrm{X}, \mathrm{EB} .2))$

602 EORMAT $(/ / 40 X, * 2$. RELEASE DATA*,//55X, "RELEASE MODE *,A7,/55X, "LEA $(Y) * 1$

$\mathrm{C}=\mathrm{B}(1)$ (I) $\mathrm{NE} .1) \quad \mathrm{C}=\mathrm{B}(2)$

IF $=$ (IBC.EQ.1) $C=F(2)$

IF (IBC.EQ.1) $6=F(2)$

603 FORMAT (//40X, 3. CALCULATION DATA* //55X,A7, 8X, A7, "CONDITION",

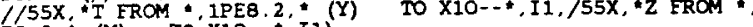

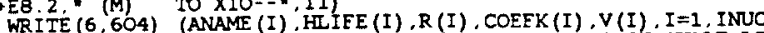

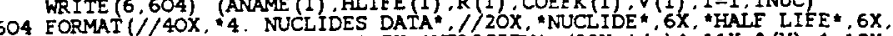

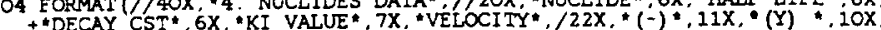
*(IS) .10X,*(-)*,12X,*(M/Y)*./3(20X.A7,1P4E15.3.j)

$E=D(1) . N E$. 1) $E=D(2)$

WR ITE $(6,605)$ E, E, (ANAME (I), CURIN (I), ONX (I), PR (I), RCGW (I), I=1, INUC)

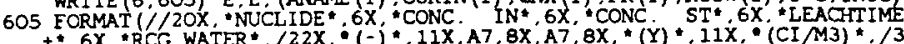
*6X."RCG WATER*.122X

$+(20 X, A 7,1 \mathrm{P} 4 \mathrm{E} 15,3,1)$

606 FORMAT (IHI)

RETURN

SURROUTINE TITLE2 (ICAL, IDOUT, TZ)

, RCGW (3) .DIE, VEL, ELW,TS,TI,Z1, IT, IZ

DATA $=A$

IF (ICAL . EQ.1) $C=B$

IF (IDOUT EO 1) CO TO 10

WRITE $(6,650$ ) C.TZ, (ANAME (I) , I=1, 3), (ANAME (I) , I=1, 3)

RETURN

10 WRITE $(6,650)$ C, TZ, (ANAME $(I), I=1,3$ ) , (ANAME (I) , I=1, 3) (ANAME (I) $, I=1,3$ )

650 FORMAT $(/ / / A 5,1 P E 10,3,14 X, 3(2 X, A 7,1 X), 4 X, 3(2 X, A 7,1 X)$

$+, 4 X, 3(2 X, A 7,1 X))$

SUBROUTINE GAUSS (ENM,A,B,Q)

$Q=0$
$A B=(A+B) / 2$
$B A=(B-A)$

$\stackrel{c}{c}$

10 POINT GAUSSIAN-LEGENDRE QUADRATURE FORMULA

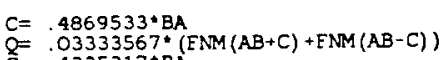

$C=4325317 * \mathrm{BA}$
$\mathrm{O}=\mathrm{Q}+.07472567 *(E N M(A B+C)+E N M(A B-C))$

$C=3397048^{*} \mathrm{BA}(\mathrm{ENM}(\mathrm{AB}+\mathrm{C})+\mathrm{FNM}(\mathrm{AB}-\mathrm{C}))$

$C=Q^{+}+1095432^{*}(E N M(A B+C)+F N M(A B-C))$

$Q=Q^{+} .1346334^{*}(E N M(A B+C)+F N M(A B-C))$

Q= Q"BA

END

SURROUTINE ESYM (W, $S, X, Y$, ANS

COMMON/CAL $2 / C S(3,3,3), \operatorname{BT}(3,3), R(3), V(3), E K, X G, Z Z, I B C, I E R, B B, T T, X I$ PHI $=A C O S(-1$.

SUM $1=0$.

IF $($ IBC. EQ O O) THEN

$\operatorname{COE} 1=-\operatorname{Sin}$ (S)

$\operatorname{COE} 2=\cos (\mathrm{S})$

$\operatorname{COE} 1=\cos (S)$
$\operatorname{COE} 2=\operatorname{SIN}(S)$

END IF
70 SUM $1=S U M 1+F U N R(N, X) *$ FUNE $(N, X, Y, W)$

SUM $2=S U M 2+E U N R(N, X)$ EUNG

ANS $=2$ * EXP $(W) *(C O E 1+C O E 2 * Y / P H I)-2 . * \operatorname{SUM} 1 * E U N V(X) * \operatorname{COE} 1+$

2. 2 SUM 2 * EUNV $(X) * \operatorname{COE} 2$

ELSE $(X)$ IT 0 5) THEN

$X O X=1 .-E R E S(X)$

$X X X=\operatorname{ERFL}(X) * \operatorname{EXP}(-X * * 2)$

END IE *2. *COEI*FUNV $(X) * \operatorname{SUM} 1+2 * * E X(W) * \operatorname{COE} 2 * E U N U(X) * \operatorname{SIN}(2 . * X * Y)$

IF (ABS (ANS) .LT. I.E-100) CO TO 80

IF (ABS (AAA). LT.1.E-16) CO TO 60

IF (ABS (ANS

$N=N+1$

$C O$ TO 70

80 ANS $=0$.

END

EUNCTION EUNE (N,X,Y,W)

$E L N=F L O A T$
$P P=E X P(N+E L N * Y-E L N * * 2 / 4$

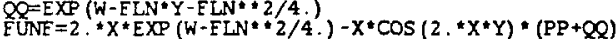

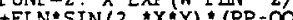

RETRR

END

EUNCTION FUNG $(N, X, Y, W)$

FLN=ELOAT $(N)$

$P P=E X P(W+E L N * Y-F L N * 2 / 4$

$Q Q=E X P(W-E L N+Y-F L N * 2 / 4$

FUNC $=X * \operatorname{SIN}(2 * X * Y) *(P P+Q Q)+E L N * \operatorname{COS}(2 . X * Y) *(P P-Q Q)$

RETURN

FUNCTION FUNR $(N, X)$

FLN=FLOAT $(N)=* 2+4 \cdot x * * 2)$

FUNR=

END

FLNCTION FUNU $(X)$

PHI $=A C O S(-1$,

FUNU $=E X P(-X * * 2) /(2 * P H I * X)$

RETURN

5 EUNU $=1$. E99

RETURN

EUNCTION FUNV (X)

$P H I=A C O S(-1)$

RETURN

[EOR]

100 . 2 . 5E-02 $3.04 \mathrm{EO}$

$1 \quad 350 \cdot 5.60 E 08$

$\begin{array}{lrr}9 & 9 & 100 .\end{array}$

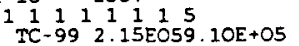

11111

100 . $\frac{1}{2}, 5 E-02$ 3.04EO2

$1 \quad 350^{\circ}, 5.60 E 08$

$59 \quad 100$

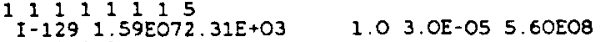

100 . $2.5 E-02 \quad 3.04 E O 2$

$1,350,5.60 \mathrm{EOB}$

59200

$1 \frac{1}{1} 1^{1}{ }^{1} \frac{1}{1} \frac{1}{5}-10 E+O 3 \quad 1000.0 \quad 3.0 E-O S \quad 5.60 E O 8$

11111

120 . $\frac{1}{2}$. 5E-02 $3.04 \mathrm{EO} 2$

$59^{1} 9^{350} 100$.

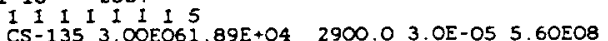

11111 1 100 . $5 E-029.10 E O 1$

$1350.1 .87 E O 9$ 

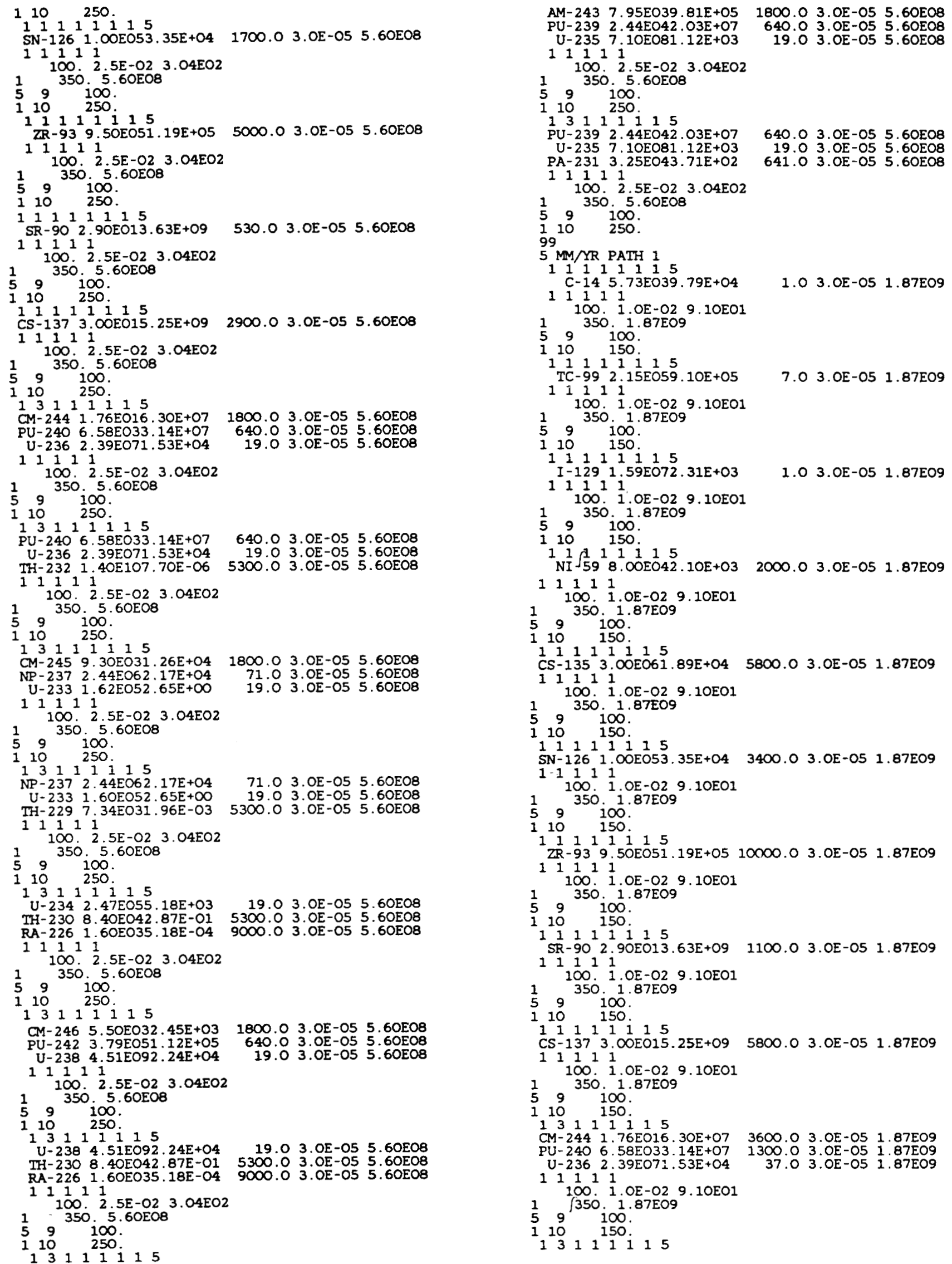


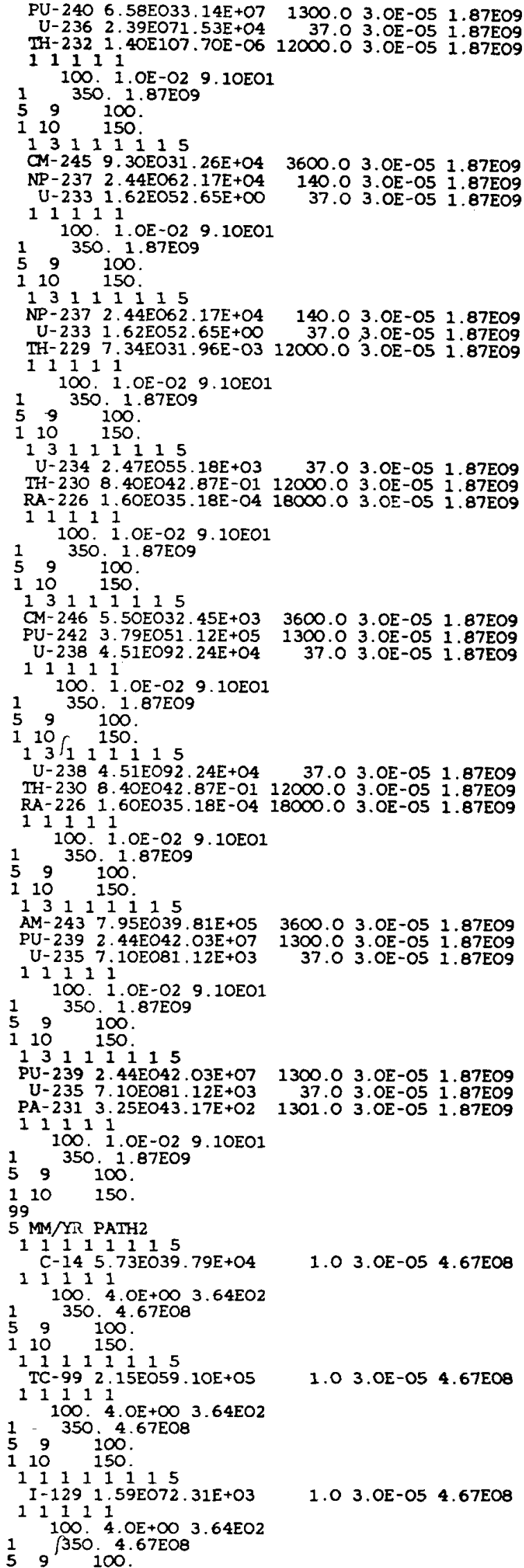

PU-240 6.58E033.14E+07 1300.0 3.OE-05 1.87EO9 U-236 2.39EO71.53E+04 37.0 3.OE-O5 I. B7EO9 TH-232 $1.40 E 107.70 E-06 \quad 12000.0$ 3.OE-05 1.87EO9 11111

$100.1 .0 E-02$ 9.1OEO1

$199^{350} i 100$.

$110 \quad 150$

$\begin{array}{llllllll}1 & 3 & 1 & 1 & 1 & 1 & 1 & 5\end{array}$

CM-245 $9.30 E O 31.26 E+04$

$\mathrm{NP}-2372.44 \mathrm{EO62} .17 \mathrm{E}+04$

$\mathrm{U}-2331.62 \mathrm{E} 052.65 \mathrm{E}+\infty$

3600.0 3.OE-O5 1.87EO9

$1111 ; 102 \mathrm{COS2} .65 \mathrm{E}+\infty$

140.03 OE-05 $187 \mathrm{EOS}$

37. O 3.OE-OS 1.87EO9

$1 \quad 350 \cdot 1.0 \mathrm{E}-\mathrm{O2}$

$\begin{array}{lrr}5 & 9 & 100 \\ 1 & 10 & 150\end{array}$

$\begin{array}{llllllllllll}1 & 3 & 1 & 1 & 1 & 1 & 1 & 5\end{array}$

NP $-2372.44 E 062.17 E+04 \quad 140.03 .0$ OE $-051.87 E O 9$

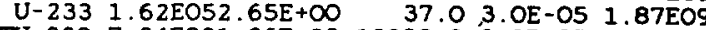
TH-229 7.34EO31.96E-03 12000.0 3.0E-05 1.87EO9

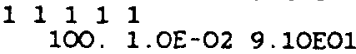

$1350.1 .87 \mathrm{EO9}$

$\begin{array}{lrr}5 & 9 & 100 \\ 1 & 10 & 150\end{array}$

$\begin{array}{lllllllll}1 & 3 & 1 & 1 & 1 & 1 & 1 & 5\end{array}$

U-234 2.47E055.18E+03 $37.0 \quad 3.0 \mathrm{E}-05$ 1.87EO9 TH- 230 8.40EO42.87E-O1 12000 .0 3.OE-O5 1.87EO9 RA-226 1.6OE035.18E-O4 18000.0 3.0E-O5 1.87EO9

$\begin{array}{llll}1 & 1 & 1 & 1 \\ & 100 & 1 . O E-O 2 & 9.1 O E O 1\end{array}$

$1350 \cdot 1.87 \mathrm{EO}$

$\begin{array}{lll}5 & 9 & 100\end{array}$

$\begin{array}{lllllll}1 & 10 & 150 & 1 & 1 & 1 & 5\end{array}$

CM- 246 5.5OEO32. $45 \mathrm{E}+03$

PU-242 3.79EO51.12E+O5

$U-238$ 4.51EO92.24E+O4

11111

100. 1. OE-O2 9.1OEO1

1 350. 1.87 EO9

19100

${ }_{1}^{10} \int_{1}{ }_{1}^{150}$; 15

U-238 $4.51 E 092.24 E+04$ TH- 230 8.40EO42.87E-OI 12000.0 3.OE-O5 $1.87 \mathrm{EO9}$ RA-226 1.6OEO35.18E-04 18000.0 3.OE-05 1.87EO9 11111

$$
100 \text {, 1.OE-O2 9.1OEO1 }
$$

$1350.1 .87 \mathrm{EOS}$

59100 .

110,150

$A M-2437.95 \mathrm{EO} 39.81 \mathrm{E}+05$

PU- $2392.44 \mathrm{EO} 22.03 \mathrm{E}+07$

$\mathrm{PU}-239$
$\mathrm{U}-235$
$2.10 \mathrm{~L} O 81,12 \mathrm{E}+03$

${ }_{1}-2357_{i}$

1100 1.OE-O2 9.1OEO1

$3600.0 \quad 3.0 \mathrm{E}-05 \quad 1.87 \mathrm{EO9}$ 1300.0 3.OE-O5 $1.87 \mathrm{EO9}$

$\frac{1}{5} 9^{350} ; 100.87$ EO9

$1 \quad 10 \quad 150$

$\begin{array}{lllllllll}1 & 3 & 1 & 1 & 1 & 1 & 1 & 5\end{array}$

PU- $2392.44 E 042.03 E+07$

$\mathrm{U}-2357.10 \mathrm{E} 081.12 \mathrm{E}+03$

1300.0 3.OE-05 $1.87 \mathrm{EO9}$

$\mathrm{PA}-2313$. 25EO43 17E+O2 1301.O 3.OE-O5 1.87EO9

11111

1100.1 .OE-02 9.1OEO1

$59^{350 .} i 0^{1.87 E 09}$

110150

99

$5 \mathrm{MM} / \mathrm{YR}$ PATH2

$\begin{array}{llllllll}1 & 1 & 1 & 1 & 1 & 1 & 5\end{array}$

C-14 5.73EO39.79E+O4

$\begin{array}{llllllll}1 & 1 & 1 & 1 & 1\end{array}$

$100.4 . O E+\infty \quad 3.64 E O 2$

$3600.03 .0 \mathrm{E}-05$ 1.87EO9

1300.0 3.OE-O5 $1.87 \mathrm{EO}$ 37.0 3.0E-O5 1.87EO9

$9^{350} 100$

110150 .

$\begin{array}{llllllll}1 & 1 & 1 & 1 & 1 & 1 & 1 & 5\end{array}$

TC-99 2.15EO59.10E+O5

$\begin{array}{llllll}1 & 1 & 1 & 1 & 1\end{array}$

100 . 4.OE $+\infty \quad 3.64 E O 2$

$\frac{1}{5}-350,4.67$ EOB

59100

$1011^{150}$ i 1

1 I- $129^{1} 1.59 \mathrm{EO} 72.31 \mathrm{E}+03$

$11 \frac{1}{100} 4.0 \mathrm{O}+\infty \quad 3.64 \mathrm{EO} 2$

$59^{1350} 100$.

1.0 3.OE-O5 4.67EO8

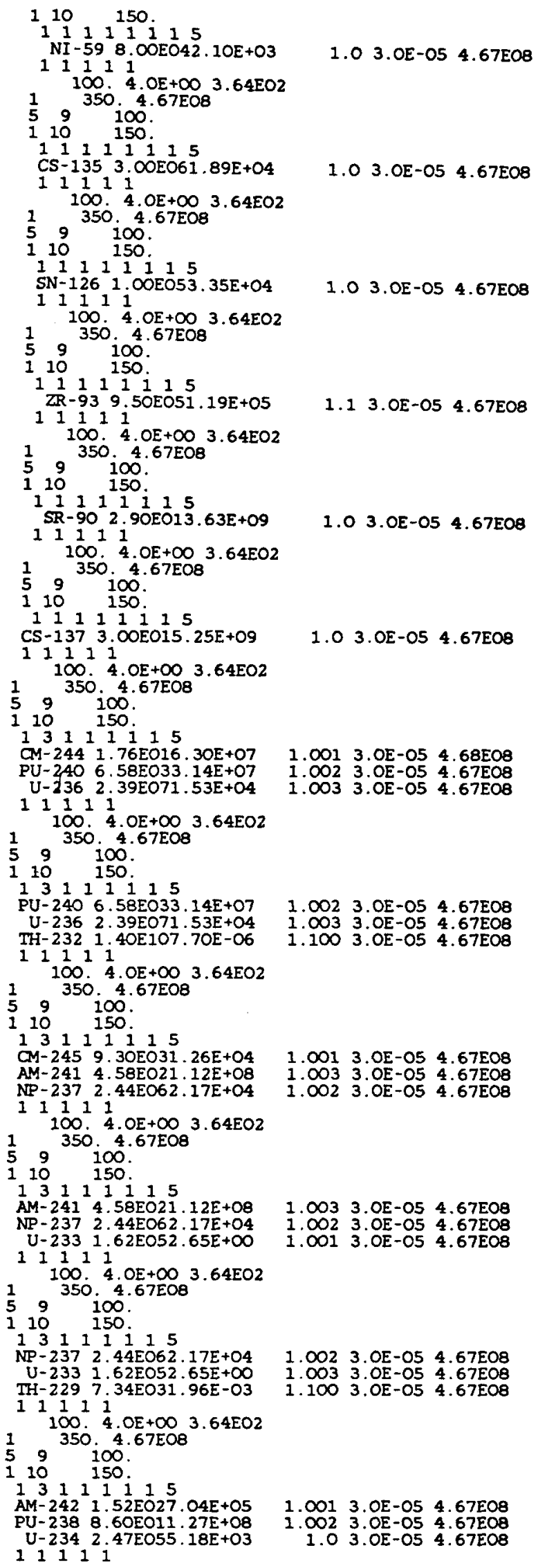
${ }_{1}^{U}{ }_{1} 1_{1}{ }_{1}$

1.002 3. OE-O5 4.67EOB $1 . \infty 3$ 3.OE-05 4.67EOB 1.100 3.OE-OS 4.67EO8

$\begin{array}{lll}1.001 & 3.0 E-05 & 4.68 E O 8\end{array}$

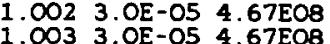

$1.03 .0 E-05 \quad 4.67 E 08$

$1.03 .0 \mathrm{E}-05 \quad 4.67 \mathrm{EOB}$

$1.03 .0 E-O 5 \quad 4.67 E O 8$

1.1 3.OE-O5 4.67EOB

1.0 3.OE-O5 4.67EO8

$1.001 \quad 3.0 \mathrm{E}-05 \quad 4.67 \mathrm{EO}$ $1 . \infty 3$ 3.OE-05 4.67EO8 1.002 3.OE-O5 4.67EO8

1.003 3.OE-O5 4.67EOB 1.002 3.OE-O5 4.67EO8 1.001 3.OE-O5 4.67EO8

1.001 3.OE-O5 4.67EO8 1.002 3.OE-OS $4.67 \mathrm{EOB}$ 1.0 3.OE-O5 $4.67 E 08$ 


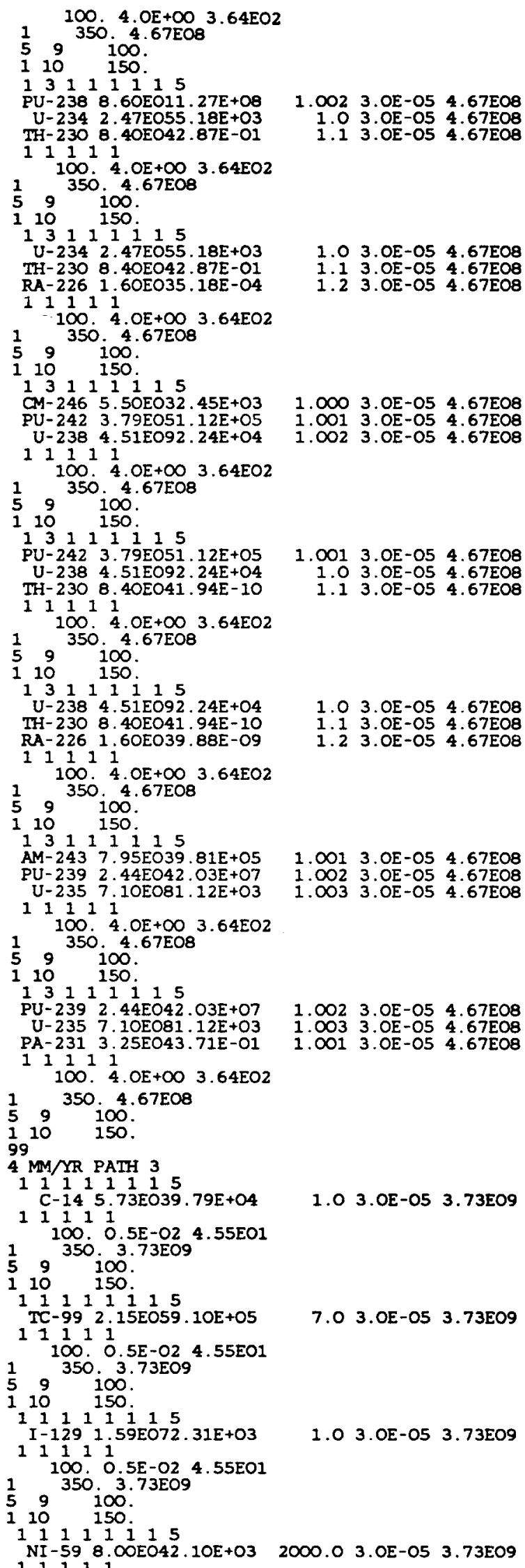




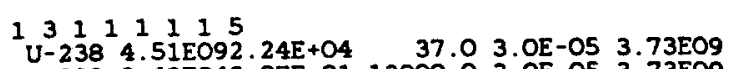

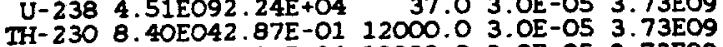
RA-226 1.60EO35.18E-04 18000.0 3.OE-05 3.73EO9 11111

$100.0 .5 \mathrm{E}-02$ 4.55EO1

$59^{350} 100$.

$110 \quad 150$

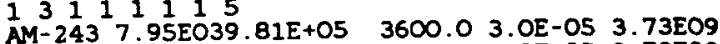

PU- $3392.44 E 042$ O3E+O7 $1300.03 .0 E-05 \quad 3.73 E O 9$

U-235 7.10EO81.12E+03 37.0 3.OE-OS 3.73EO9

11111 $\frac{1}{5} 9^{350} \cdot 3 \cdot 73 E 09$

592100.

13111 i 15

PU-239 2.44EO42.03E+07 1300.0 3.0E-05 3.73EO9

U-235 7.10EO81.12E+03 37.0 3.0E-05 3.73EO9

PA-231 3.25EO43.71E+02 1301.0 3.OE-05 3.73EO9

$\begin{array}{llllll}1 & 1 & 1 & 1 & 1\end{array}$

100 . 0.5E-02 4.55EO1

$1350,3.73 E 09$

$\begin{array}{lrr}5 & 9 & 100 .\end{array}$

$0.5 \mathrm{MM} / \mathrm{YR}$ PATH2 
B. C. Rusche (RW-1)

Director

office of Civilian Radioactive

Waste Management

U.S. Department of Energy

Eorrestal Building

Washington, DC 20585

J. W. Bennett (RW-22)

office of Geologic Repositories

U.S. Department of Energy

Forrestal Building

Washington, DC 20585

Ralph stein (RW-23)

office of Geologic Repositories

U.S. Department of Energy

Forrestal Building

Washington, DC 20585

J. J. Fiore, (RW-22)

Program Management Division

office of Geologic Repositories

U.S. Department of Energy

Forrestal Building

Washington, DC 20585

M. W. Frei (RW-23)

Engineering \& Licensing Division office of Geologic Repositories

U.S. Department of Energy

Forrestal Building

Washington, DC 20585

E. S. Burton (RW-25)

siting Division

Office of Geologic Repositories

U.S. Department of Energy

Forrestal Building

Washington, D.C. 20585

C. R. Cooley (RW-24)

Geosciences \& Technology Division

office of Geologic Repositories

U.S. Department of Energy

Forrestal Building

Washington, DC 20585
T. P. Longo (RW-25)

Program Management Division

Office of Geologic Repositories

U.S. Department of Energy

Forrestal Building

Washington, DC 20585

Cy Klingsberg ( $R W-24$ )

Geosciences and Technology Division office of Geologic Repositories

U. S. Department of Energy

Forrestal Building

Washington, DC 20585

B. G. Gale (RW-25)

siting Division

office of Geologic Repositories

U.S. Department of Energy

Forrestal Building

Washington, D.C. 20585

R. J. Blaney (RW-22)

Program Management Division

office of Geologic Repositories

U.S. Department of Energy

Forrestal Building

Washington, DC 20585

R. W. Gale (RW-40)

office of Policy, Integration, and Outreach

U.S. Department of Energy

Forrestal Building

Washington, D.C. 20585

J. E. Shaheen (RW-44)

Outreach Programs

office of Policy, Integration and outreach

U.S. Department of Energy

Forrestal Building

Washington, DC 20585

J. O. Neff, Manager

Salt Repository Project office

U.S. Department of Energy

$505 \mathrm{King}$ Avenue

Columbus, OH 43201 
D. C. Newton (RW-23)

Engineering \& Licensing Division

office of Geologic Repositories

U.S. Department of Energy

Forrestal Building

Washington, DC 20585

0. L. Olson, Manager

Basalt Waste Isolation Project office U.S. Department of Energy

Richland Operations office

Post office Box 550

Richland, WA 99352

D. L. Vieth, Director (4)

Waste Management Project office

U.S. Department of Energy

Post office Box 14100

Las Vegas, NV 89114

D. F. Miller, Director

Office of Public Affairs

U.S. Department of Energy

Post office Box 14100

Las Vegas, NV 89114

D. A. Nowack (12)

office of Public Affairs

U.S. Department of Energy

Post office Box 14100

Las Vegas, NV 89114

B. W. Church, Director Health Physics Division

U.S. Department of Energy

Post office Box 14100

Las Vegas, NV 89114

Chief, Repository Projects Branch Division of Waste Management

U.S. Nuclear Regulatory Commission Washington, D.C. 20555

Document Control Center Division of Waste Management

U.S. Nuclear Regulatory Commission

Washington, D.C. 20555
S. A. Mann, Manager

Crystalline Rock Project office

U.S. Department of Energy

9800 South Cass Avenue

Argonne, IL 60439

K. Street, Jr.

Lawrence Livermore National

Laboratory

Post office Box 808

Mail Stop L-209

Livermore, CA 94550

L. D. Ramspott (3)

Technical Project officer for NNWSI

Lawrence Livermore National

Laboratory

P.0. Box 808

Mail Stop L-204

Livermore, CA 94550

W. J. Purcell (RW-20)

office of Geologic Repositories

U.S. Department of Energy

Forrestal Building

Washington, DC 20585

D. T. Oakley (4)

Technical Project officer for NNWSI Los Alamos National Laboratory

P.O. Box 1663

Mail Stop F-671

Los Alamos, NM 87545

W. W. Dudley, Jr. (3)

Technical Project officer for NNWSI

U.S. Geological Survey

Post office Box 25046

418 Federal Center

Denver, CO 80225

NTS Section Leader

Repository Project Branch

Division of Waste Management

U.S. Nuclear Regulatory Commission

Washington, D.C. 20555

V. M. Glanzman

U.S. Geological Survey

Post office Box 25046

913 Federal Center

Denver, CO 80225 
P. T. Prestholt

NRC Site Representative

1050 East Flamingo Road

Suite 319

Las Vegas, NV 89109

M. E. Spaeth

Technical Project officer for NNWSI

Science Applications

International, Corporation

2769 South Highland Drive

Las Vegas, NV 89109

SAIC-T\&MSS Library (2)

Science Applications

International, Corporation

2950 South Highland Drive

Las Vegas, NV 89109

W. S. Twenhofel, Consultant

Science Applications

International, Corp.

820 Estes street

Lakewood, co 80215

A. E. Gurrola

General Manager

Energy Support Division

Holmes \& Narver, Inc.

Post office Box 14340

Las Vegas, NV 89114

J. A. Cross, Manager

Las Vegas Branch

Fenix \& Scisson, Inc.

Post office Box 15408

Las Vegas, NV 89114

N. E. Carter

Battelle Columbus Laboratory

office of Nuclear Waste Isolation

$505 \mathrm{King}$ Avenue

Columbus, $\mathrm{OH} \quad 43201$
J. B. Wright

Technical Project officer for NWWSI

Westinghouse Electric Corporation

Waste Technology Services Division

Nevada Operations

Post office Box 708

Mail stop 703

Mercury, NV 89023

ONWI Library

Battelle Columbus Laboratory

office of Nuclear Waste Isolation

505 King Avenue

Columbus, OH 43201

W. M. Hewitt, Program Manager

Roy F. Weston, Inc.

2301 Research Blvd., 3rd Floor

Rockville, MD 20850

H. D. Cunningham

General Manager

Reynolds Electrical \&

Engineering Co., Inc.

Post office Box 14400

Mail stop 555

Las Vegas, NV 89114

T. Hay, Executive Assistant office of the Governor

State of Nevada

Capitol Complex

Carson City, NV 89710

R. R. Loux, Jr., Director (3) Nuclear Waste Project office State of Nevada

Capitol Complex

Carson City, NV 89710

C. H. Johnson, Technical

Program Manager

Nuclear Waste Project office

State of Nevada

Capitol Complex

Carson City, NV 89710 
John Fordham

Desert Research Institute

Water Resources Center

Post office Box 60220

Reno, NV 89506

Department of Comprehensive

Planning

Clark County

225 Bridger Avenue, 7 th Floor

Las Vegas, NV $\mathbf{8 9 1 5 5}$

Lincoln County Commission

Lincoln County

Post office Box 90

Pioche, NV 89043

Community Planning and Development

City of North Las Vegas

Post Office Box 4086

North Las Vegas, NV 89030

City Manager

City of Henderson

Henderson, NV 89015

6300 R. W. Lynch

6310 T. O. Hunter

6310 NNWSICE

6311 L. W. Scully

6311 L. Perrine (2)

6312 F. W. Bingham

6312 R. R. Peters

6312 M. S. Tierney

6313 T. E. Blejwas

6313 E. A. Klavetter

6314 J. R. Tillerson

6315 Y. T. Lin (10)

6315 S. Sinnock

6332 WHT Library (20)

6335 G. E. Barr

6430 N. R. Ortiz

3141 S. A. Landenberger (5)

3151 W. L. Garner (3)

8024 P. W. Dean

3154-3 C. H. Dalin (28)

for DOE/OSTI
Dr. Martin Mifflin

Desert Research Institute

Water Resources Center

Suite 1

2505 Chandler Avenue

Las Vegas, NV 89120

Planning Department

Nye County

Post office Box 153

Tonopah, NV 89049

Economic Development Department

City of Las Vegas

400 East Stewart Avenue

Las Vegas, NV 89101

Director of Community

Planning

City of Boulder City

Post office Box 367

Boulder City, NV 89005

Commission of the

European Communities

200 Rue de la Loi

B-1049 Brussels

BELGIUM 